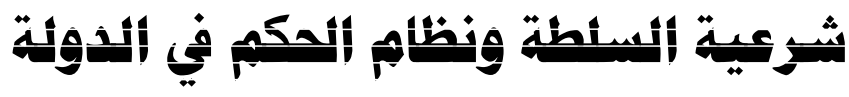

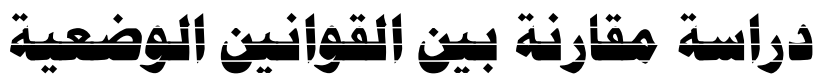

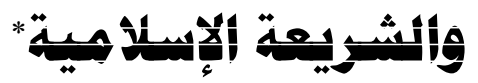

\begin{tabular}{|c|c|}
\hline 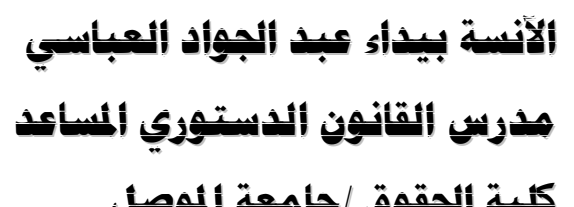 & 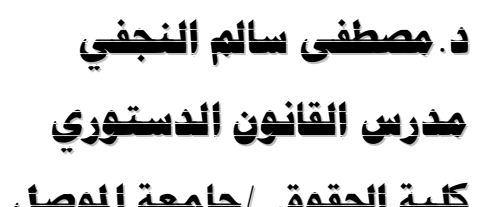 \\
\hline 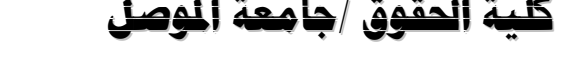 & 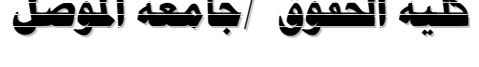 \\
\hline
\end{tabular}

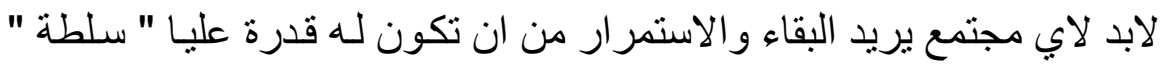

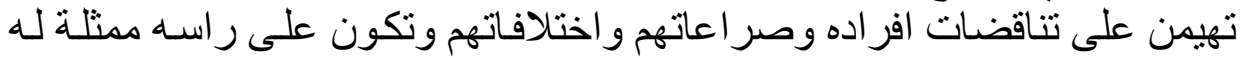

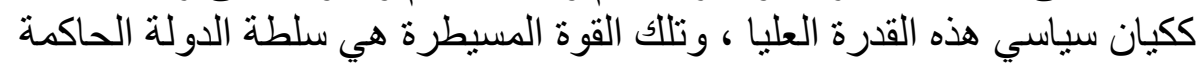

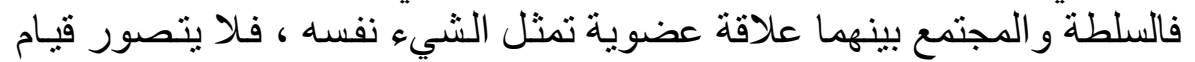

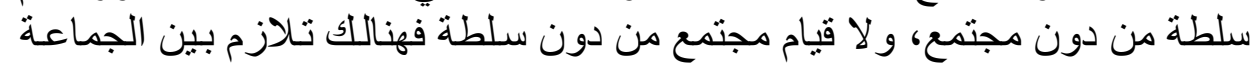

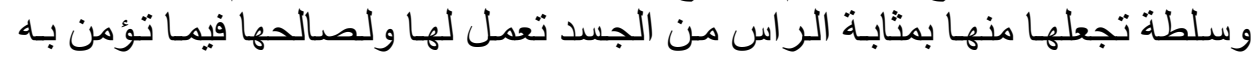

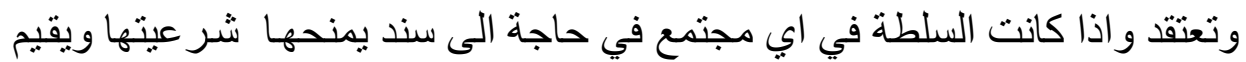

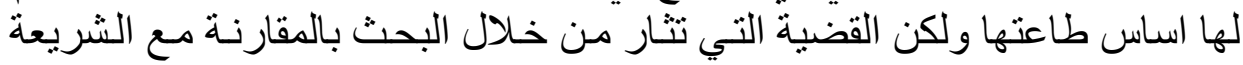

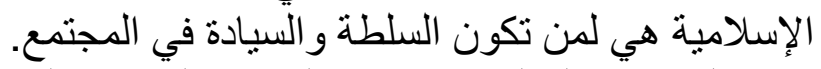

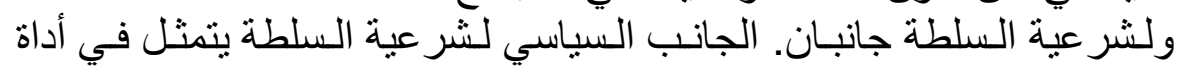

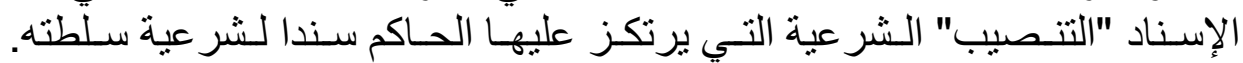

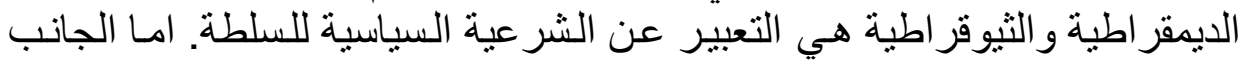

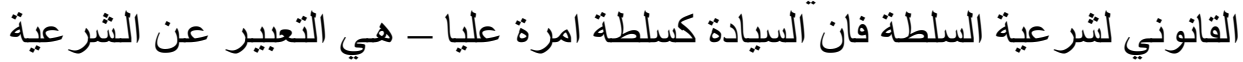

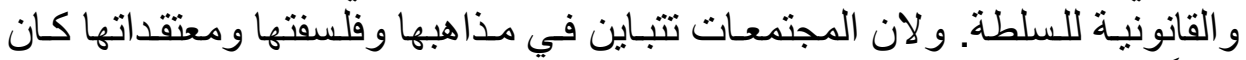

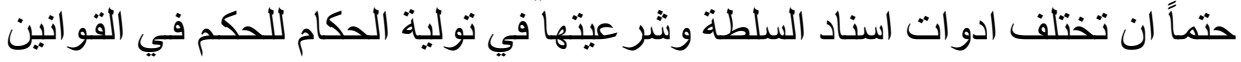

$$
\text { الوضعية و الثريعة الإسلامية. }
$$

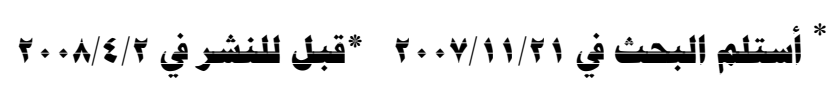




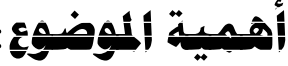

فأهمية موضوع البحث تـاتي من خلال البحث في شر عية السلطة ودر استها

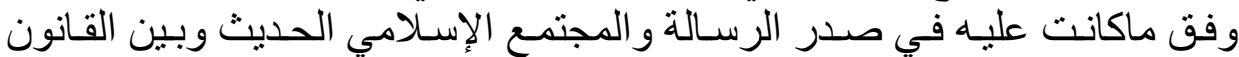

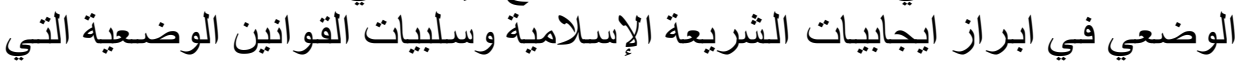

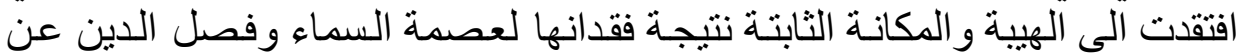

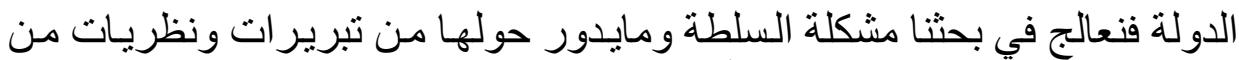

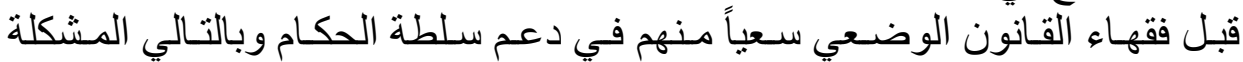

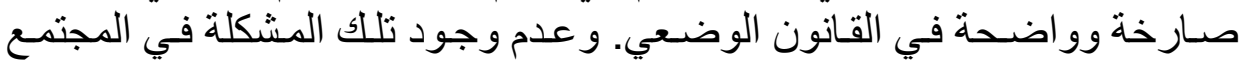

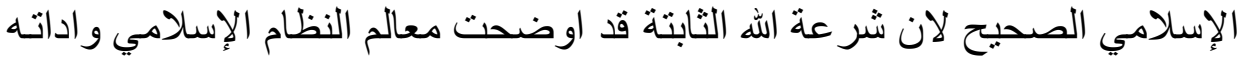

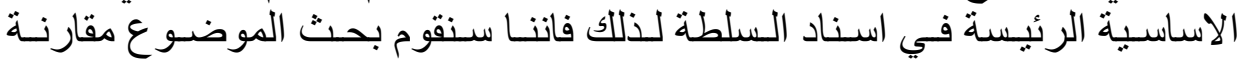
بالثر عية الإسلامية.

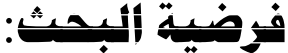

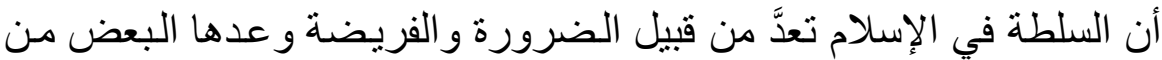

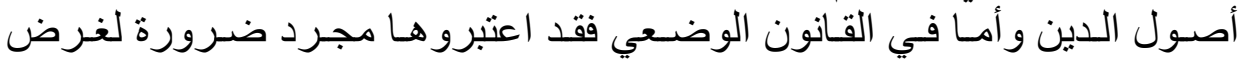
حماية الحقوق و الحريات وفض الاتي النز اعات الإنسانية ومدى مشرو عيتها.

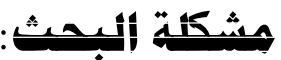

تدور مشكلة البحث في در اسـة واقع السلطة في النظلام الإسـلامي الذي كان

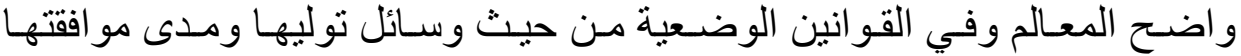

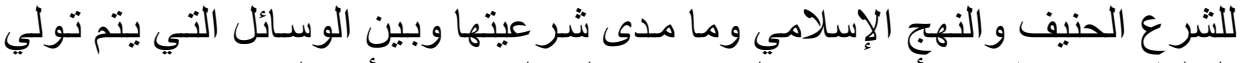

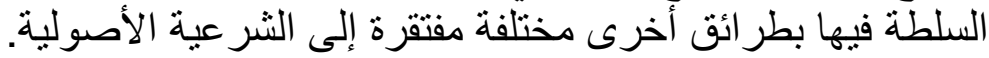

يرهذ البحث إلى الوصول إلى الوسيلة الشرعية لتولي السلطة التي اعتمدها

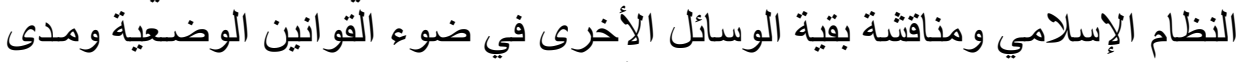

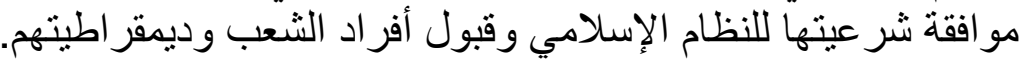


اعتمـدنا أســوب البحـث المقـارن و التـاريخي مـا بـين النظــام الإســامي و القـانون

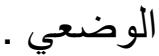

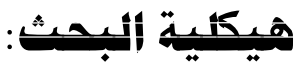
وقد قمنا بتقسيم البحث على أربعة مباحث و على الثكل الأتي :

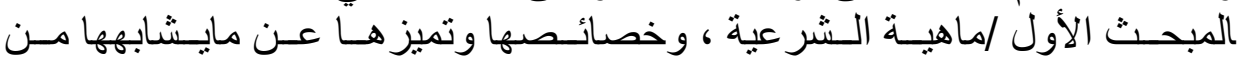
المصطلحات التصن المبحث الثاني اضرورة السلطة بالمجتمع ومشكلتها في القانون الوضعي و النظام الإسلامي المبحت المبحث الثثالث/ أساس شر عية سلطة الدولة في القو انين الوضعية والنظام الإسلامي المبحـث الر ابـع / وسـائل إسـناد الـسلطة وشـر عيتها في النظم الوضـعية و النظـام الإسلامي

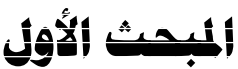

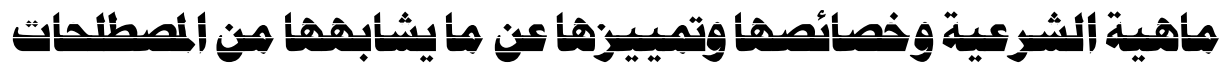

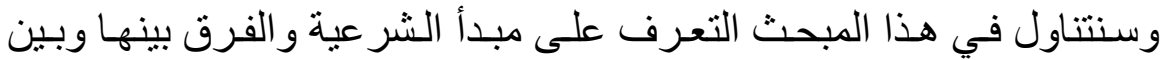
مشرو عية السلطة، وبينها وبين سيادة القانون. ونبين بعد ذلك خصائص فئس سلطة

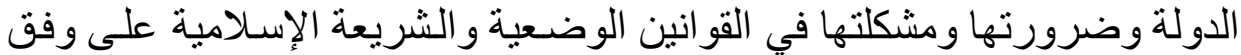
مطالب ثناثة و على النحو الأتي:-

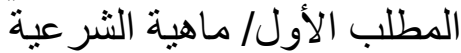
المطلب الثاني/ خصائص سلطة الدها الدولة في القانون الوضعي و النظام الإسلامي

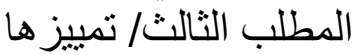

\section{أنطنب الأول}

\section{ماهية الشئية}




\section{|it}

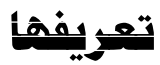

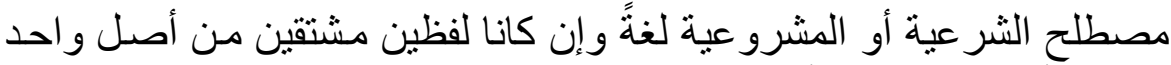

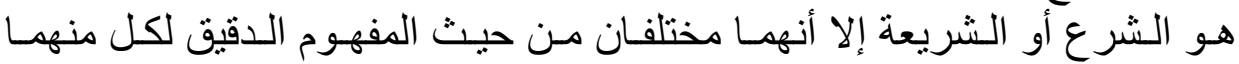

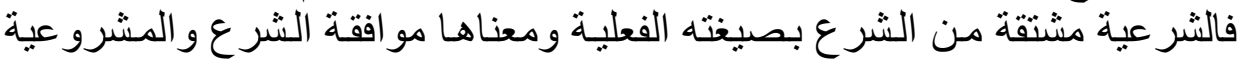

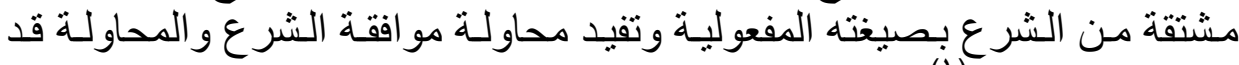

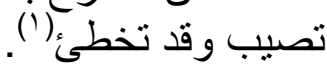

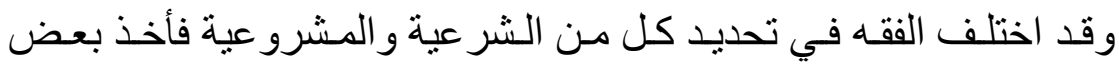

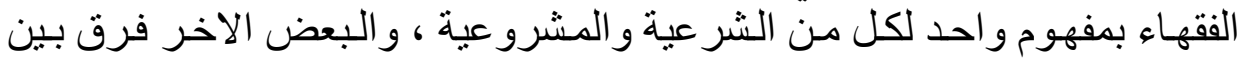

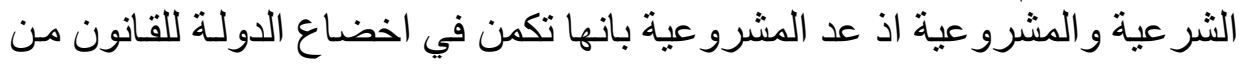

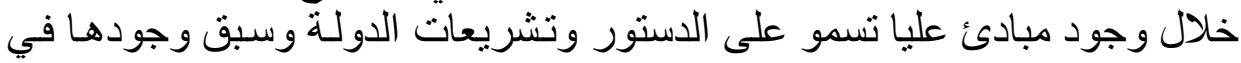

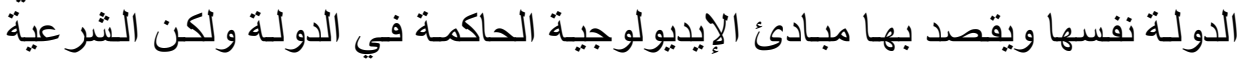

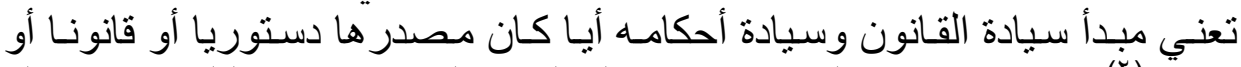

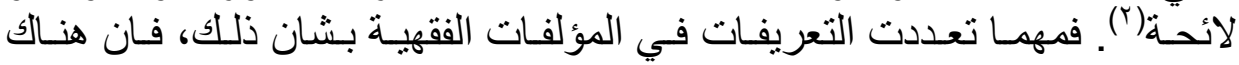

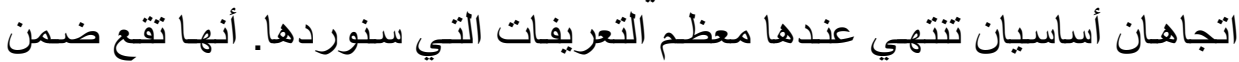

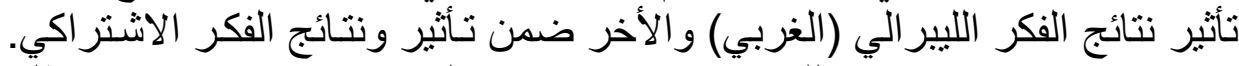

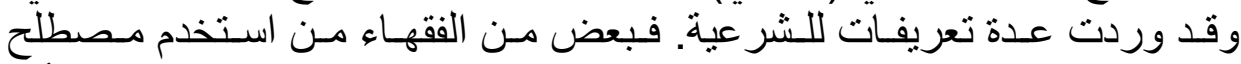

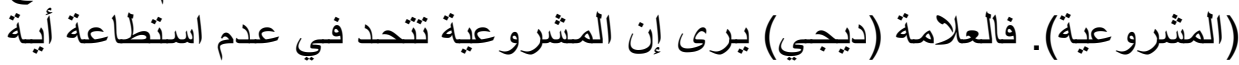

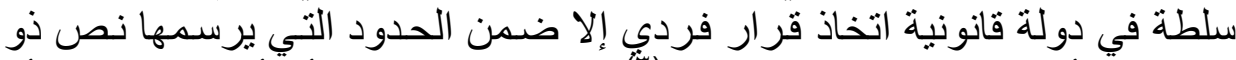

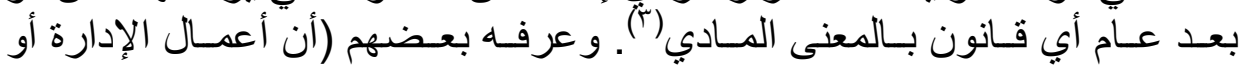

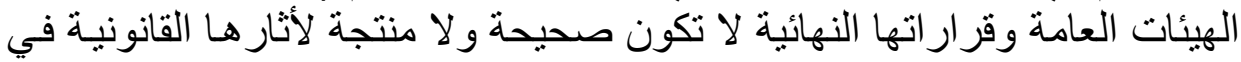

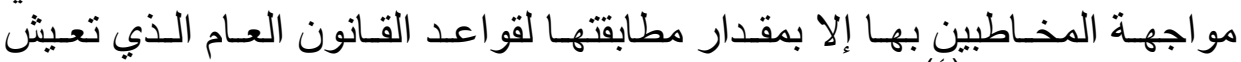

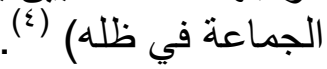

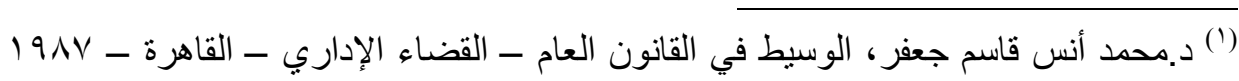

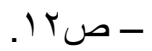

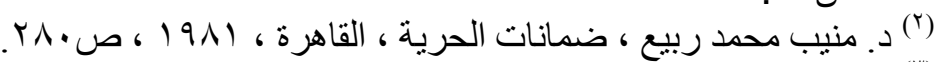

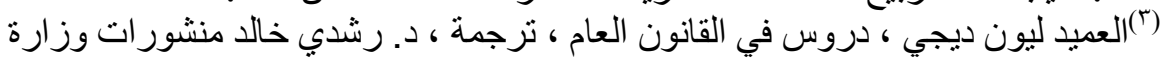

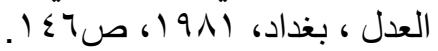

د. د. طعيمة الجرف، مبدأ المشروعية وضو ابط خضوع الدولة للقانون ، مكتبة القاهرة الحديثة

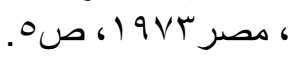


ويستعرض عدد من الفقهاء الاشتر اكيين في تعريفات للمشرو عية التي يعبر

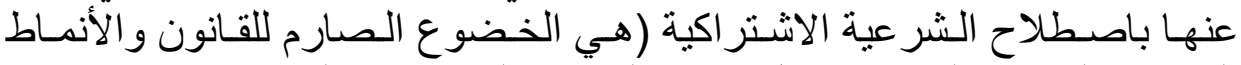

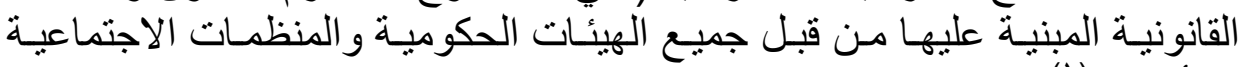

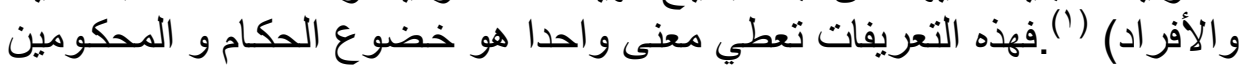

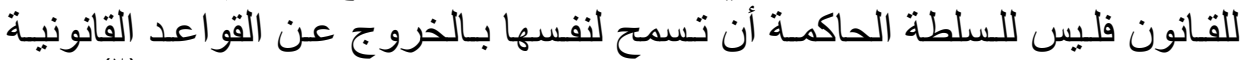

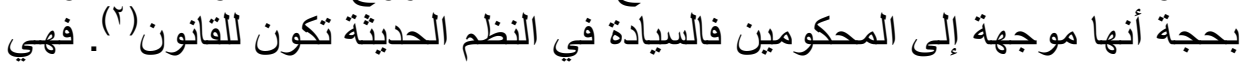

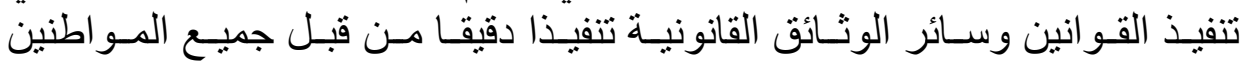

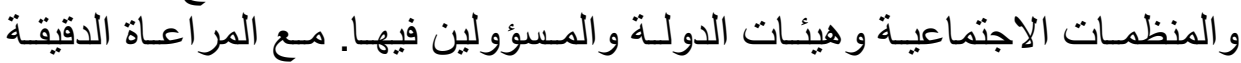

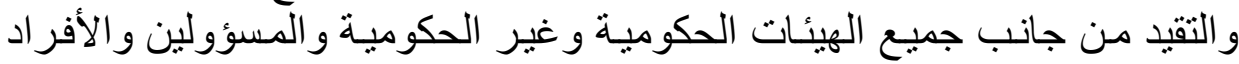

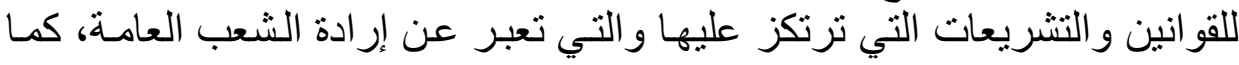

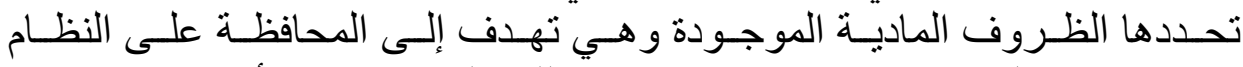

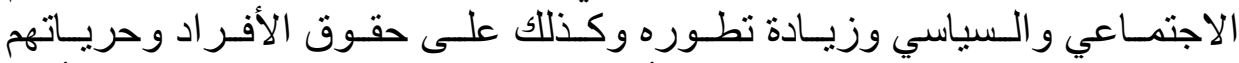

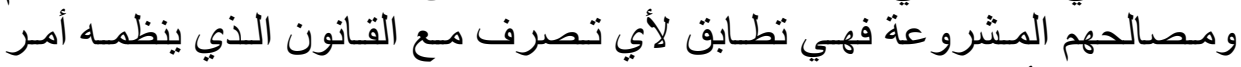
هحيح مع الأخذ بنظر الاعتبار حقيقة وطبيعة النظام السياسي الذي يسود في في ظلـانه هذا القانون.

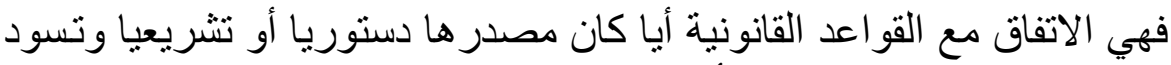

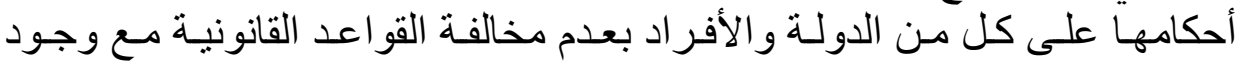

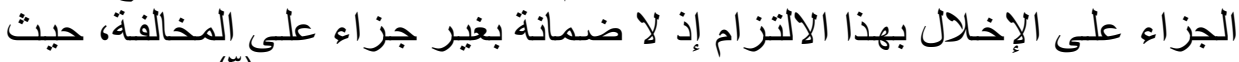

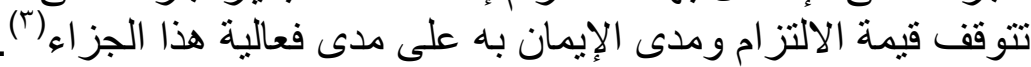

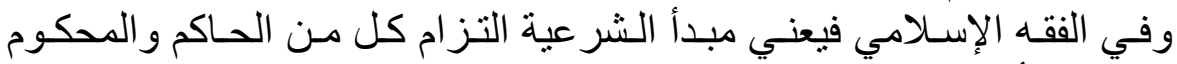

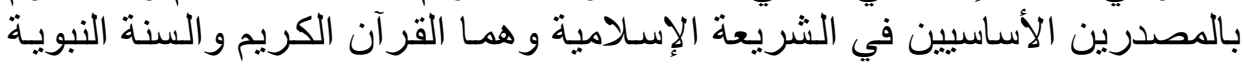

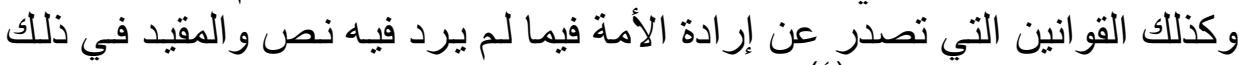
بروح الإسلام مبادئه العليا أني تصن.

${ }^{\left({ }^{\top}\right)}$ A.KH.Makhneko.The state Law of the socialist countries progress.Moscow.1976, p264.

د. علي سبتي محمد ، وسائل حماية المشرو عية ، در اسة مقارنة في ضوء التجربة العر اقية ،

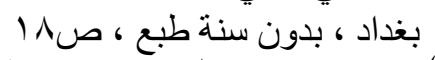

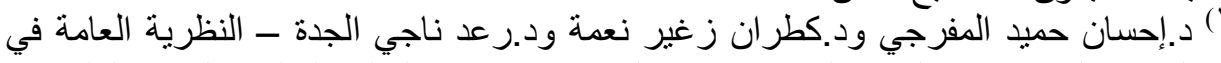

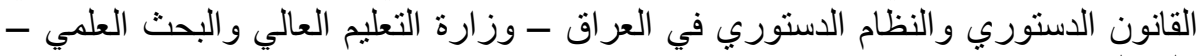

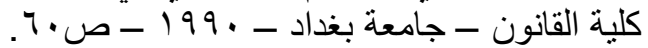

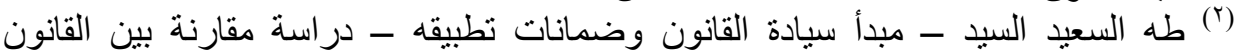

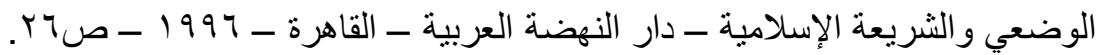


من خلال هذه التعريفات التي ذكر ها الفقهاء. فـان مبدأ الشرعية يتعلق بحدود

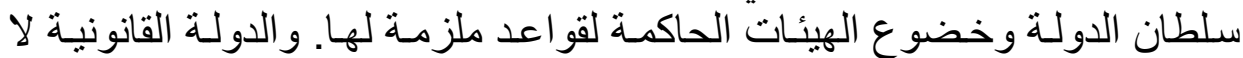

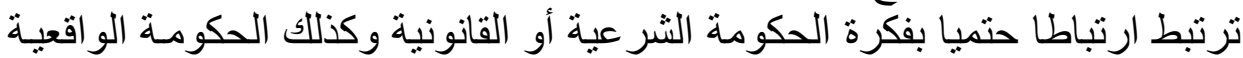

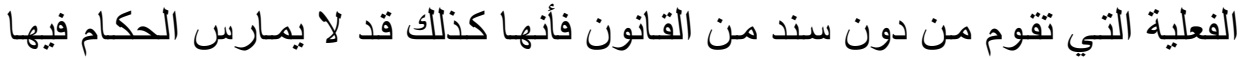

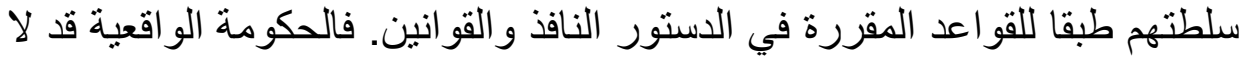

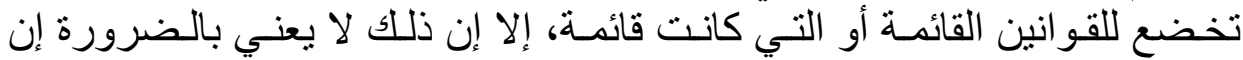

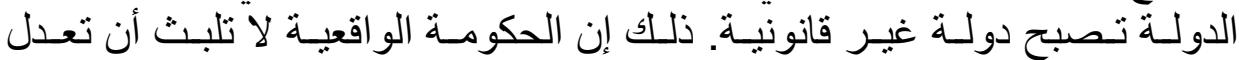

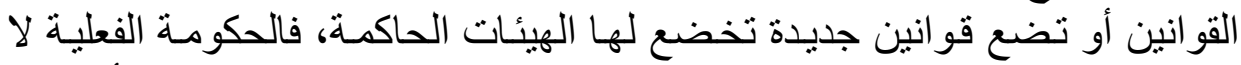

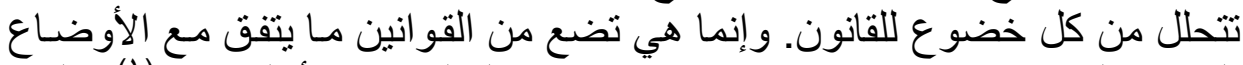

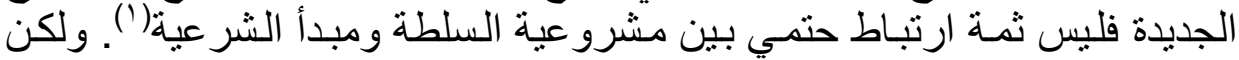

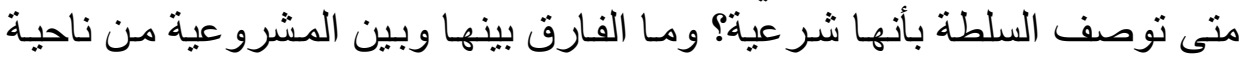
أخرى ؟ وبينها وبين مبدأ سيادة القانون؟

\section{itif ît}

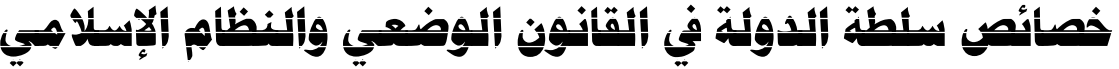

تعرف السلطة العامة على أنها قدرة التصرف الحر التي تباشـر بحكم سموها

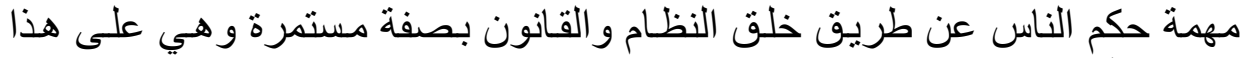

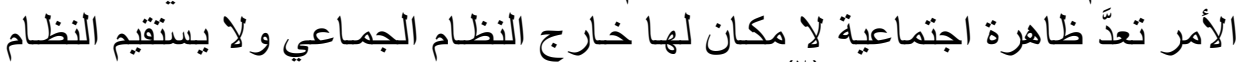

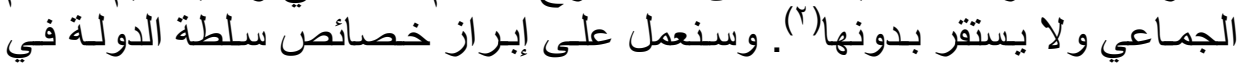

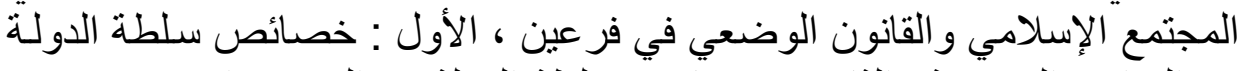
في القوانين الوضتعية والثاني : خصائص سلئ في فرعة الدولة في المجتمع الإسلامي.

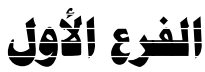

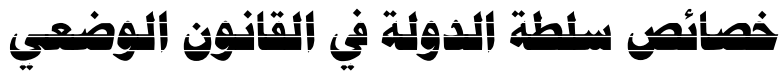

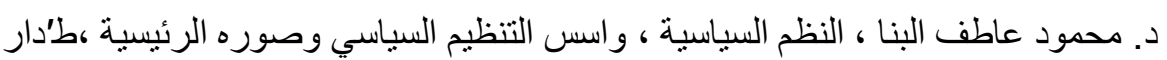

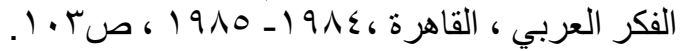

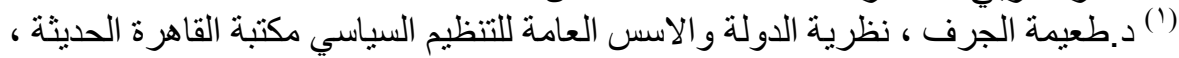

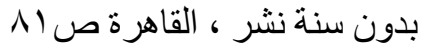




\section{أولا: السلطة ظاهرة اجتماعية:}

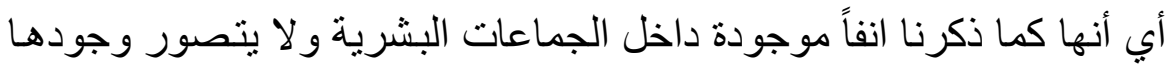

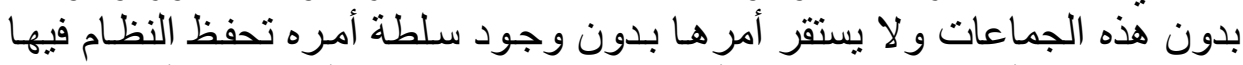

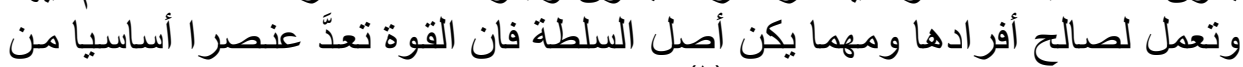

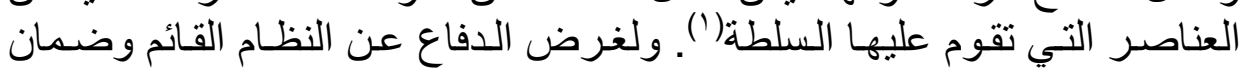

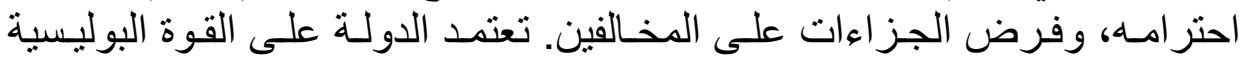

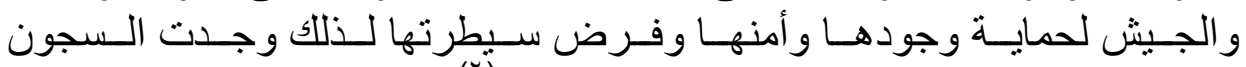

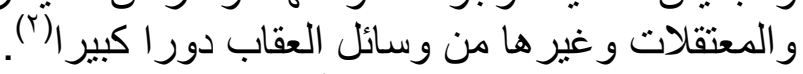

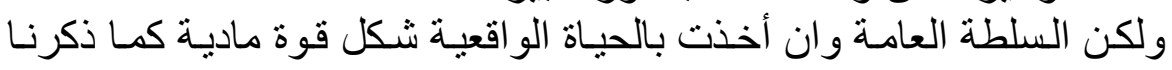

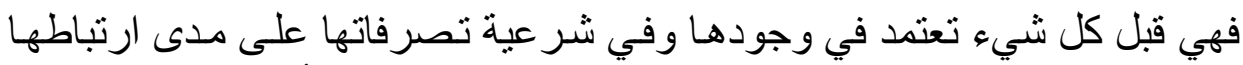

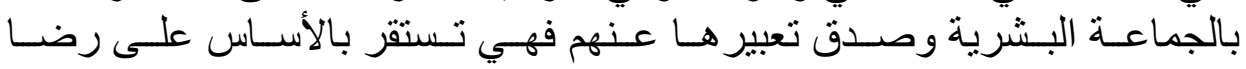

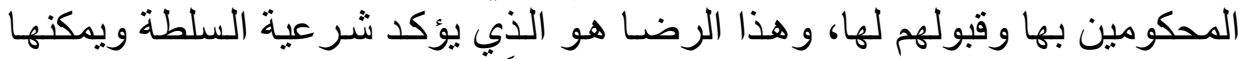

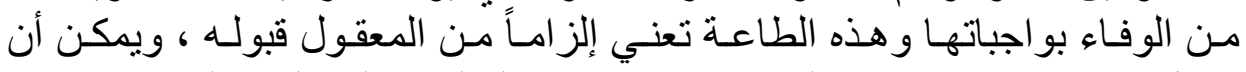

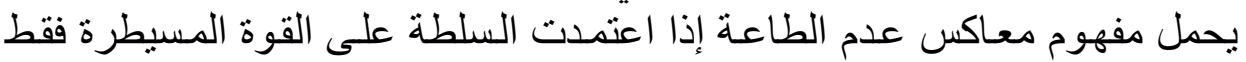

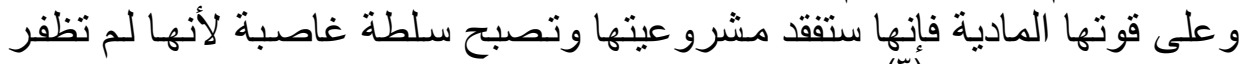

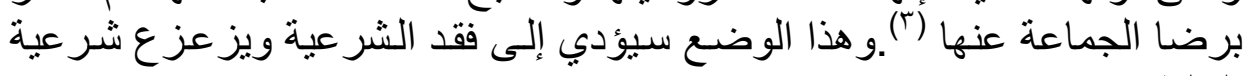

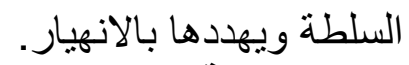
ثانيا: السلطة ظاهرة سياسية : بالانهيار

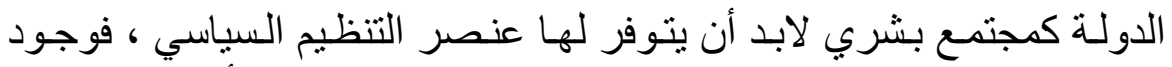

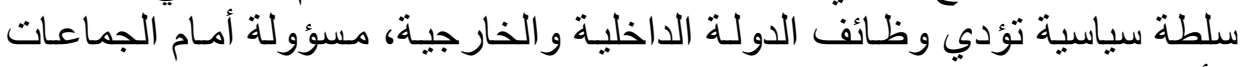

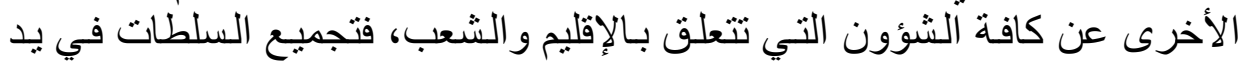

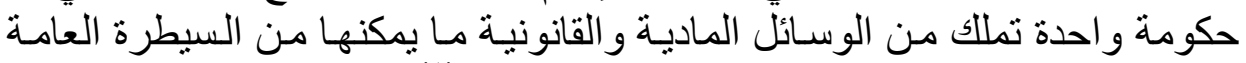

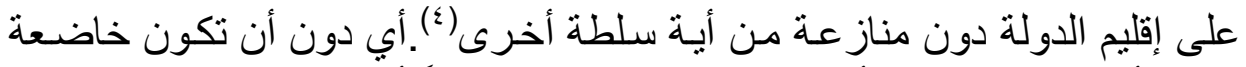

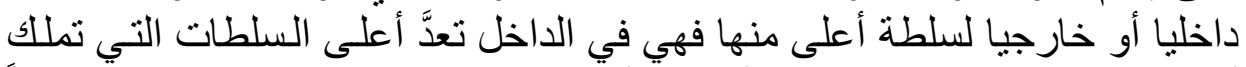

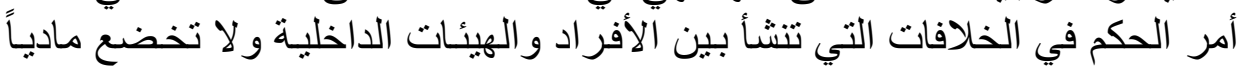

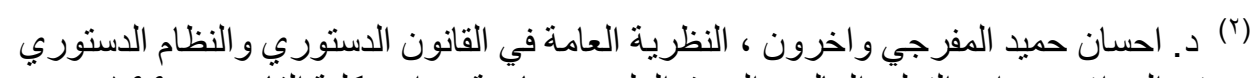

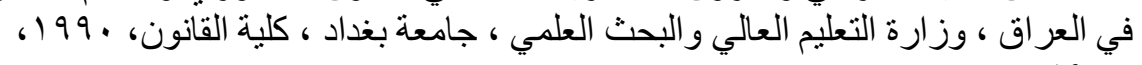
صو في العران

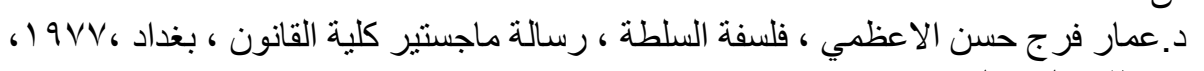
ص. ص و ومابعدها.

(') Jean-William laferreile pouvoir politique p.u.f paris.1969,p.13

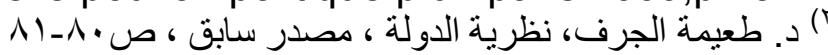




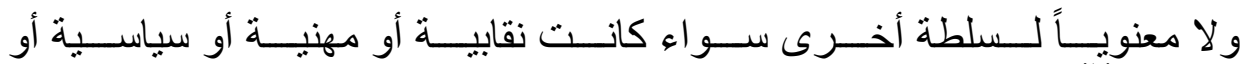
عسكرية(')فالذي يميز المجتمعات المنظمة في الدول الحديثة هو امتلاكها للسلطة ألمانة

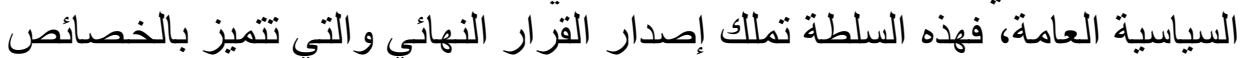
الآتية: ا - إنها سلطة شاملة لان سلطة صاحب السيادة تشمل الأفر اد كافة الذين بعيشون

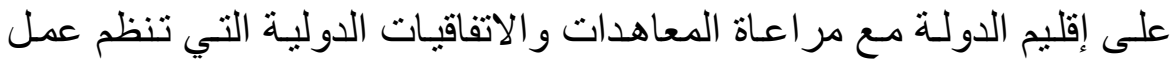

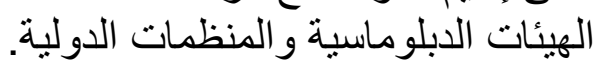

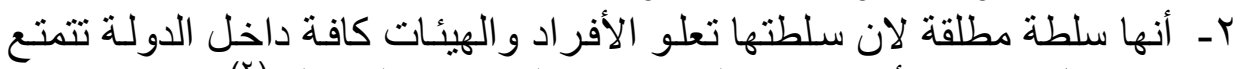

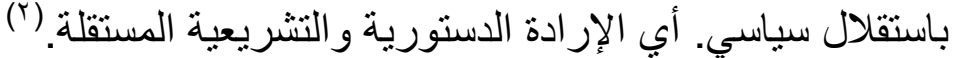

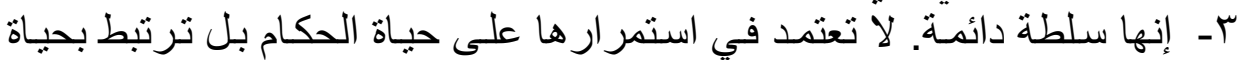
الدولة و الأمة. عـ - هي وحدة لا تتجز أ لان الهيئات التي تمارس السلطة في الدولة تستمد سلطاتها

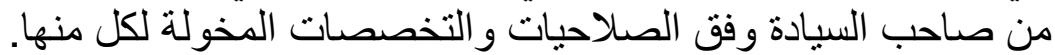

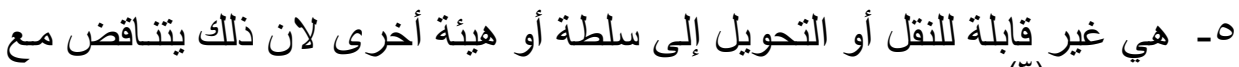
طبيعتها. (r)

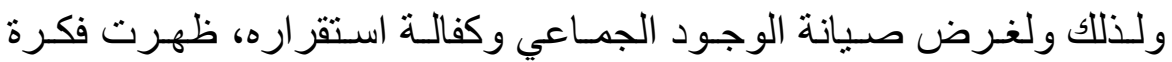

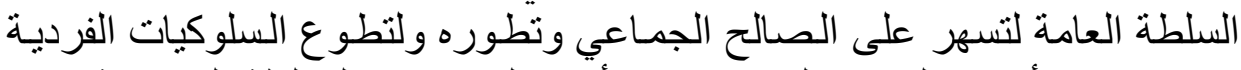

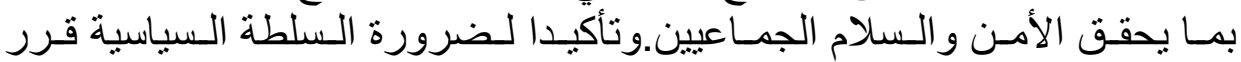

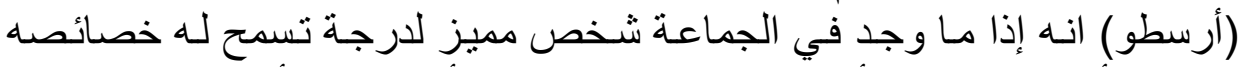

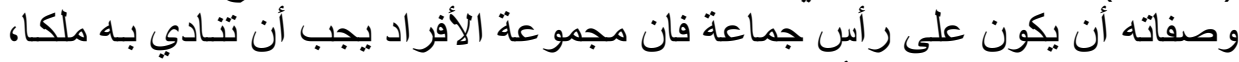

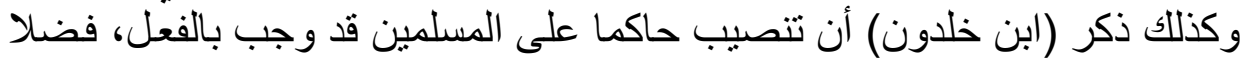

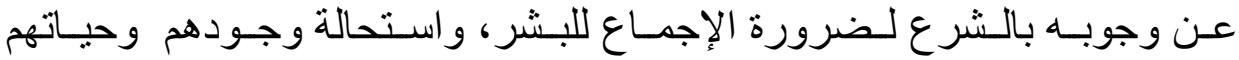

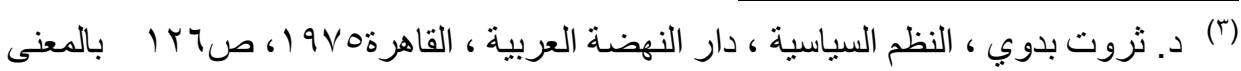

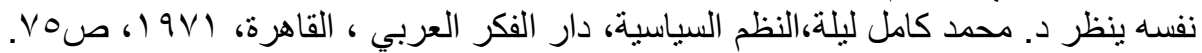

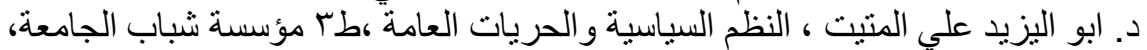

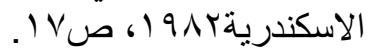

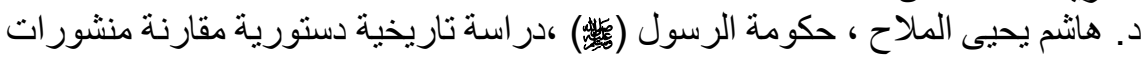

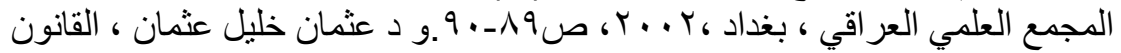

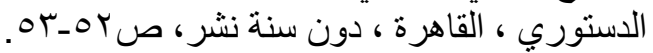




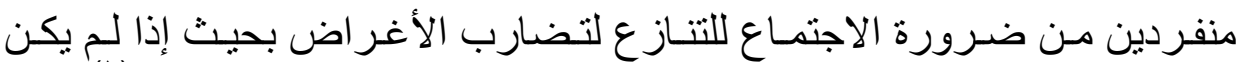

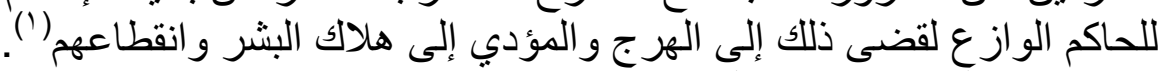

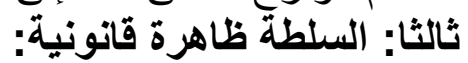

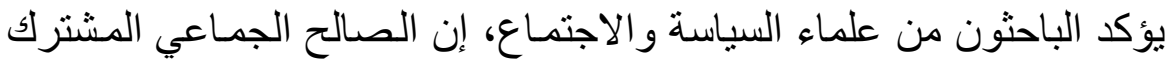

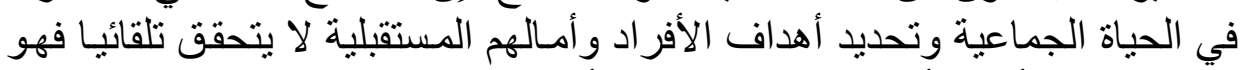

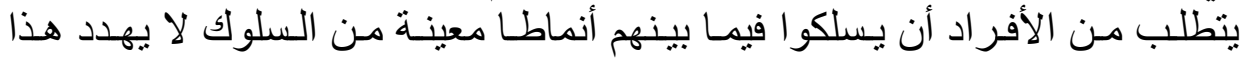

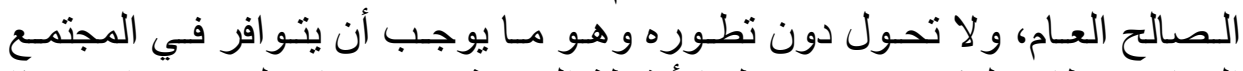

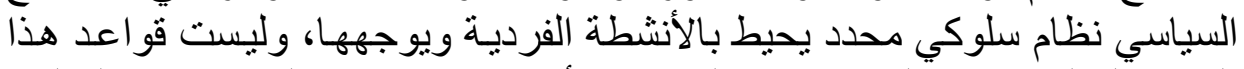

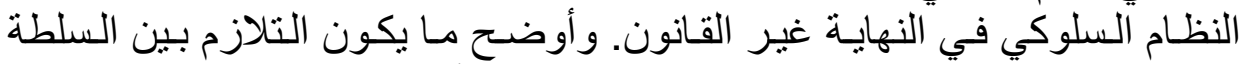

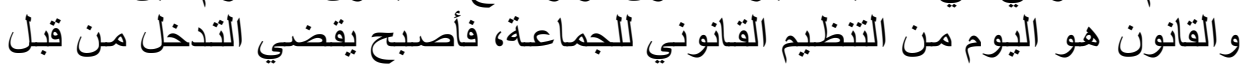

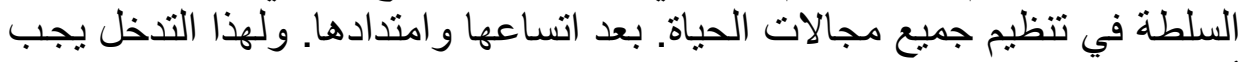

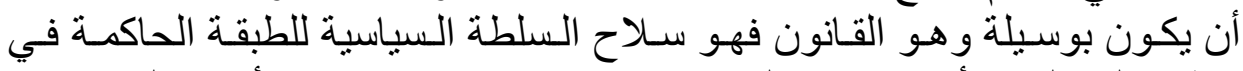

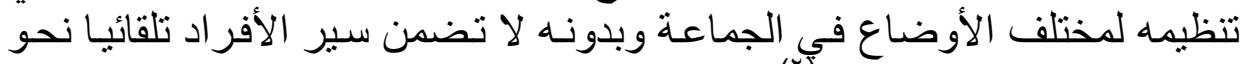

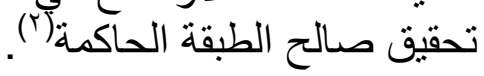

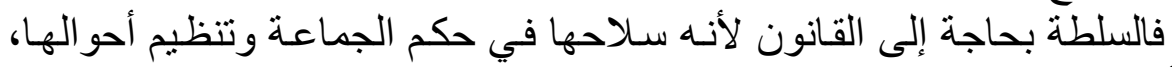

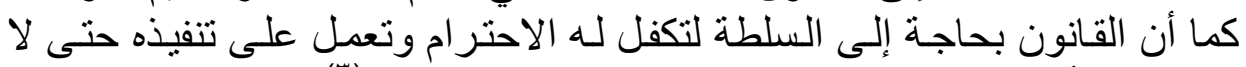

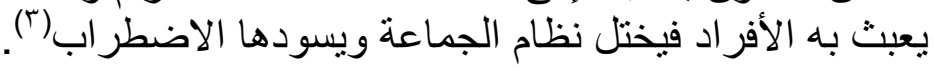

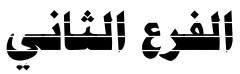

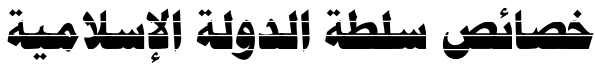

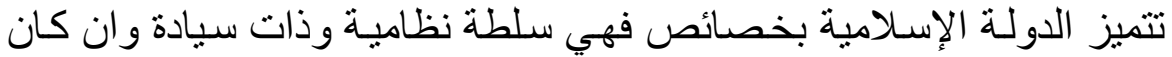

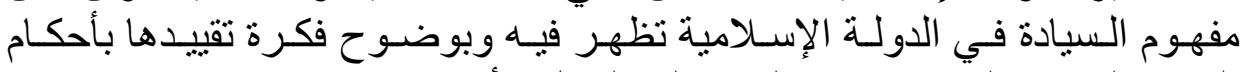

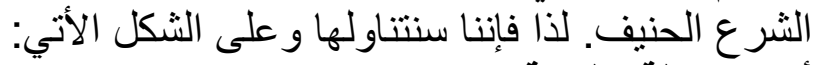
أولا: سلطة نظامية

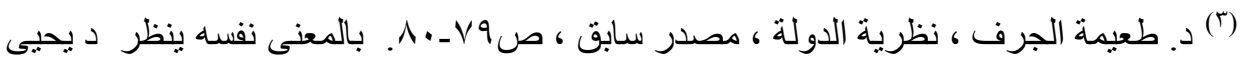

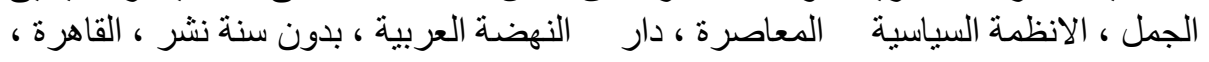

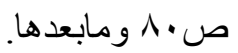

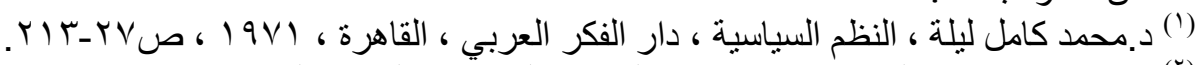

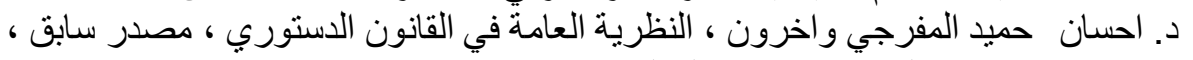

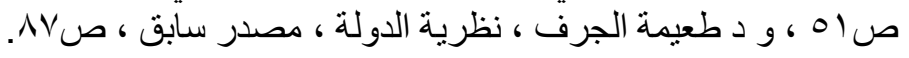




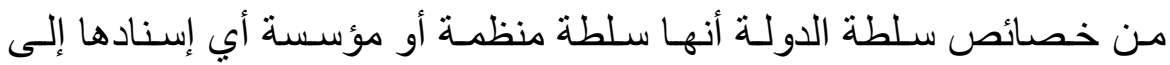

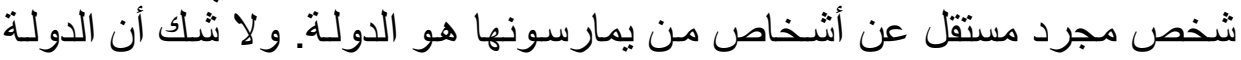

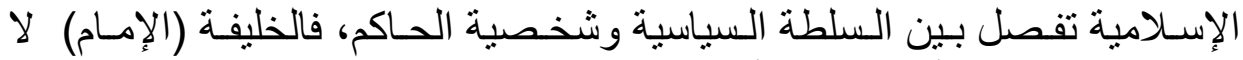
يتمتع بالسلطة على أنها ملك له أو امتياز من امتياز اته الثخصية الثية التي يستمدها من قوته المادية أو من صفاته الذاتية.

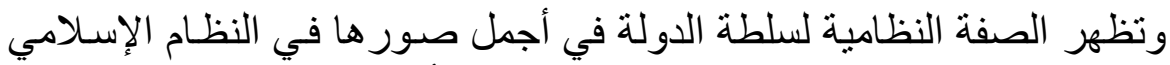

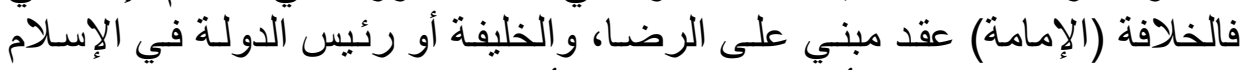

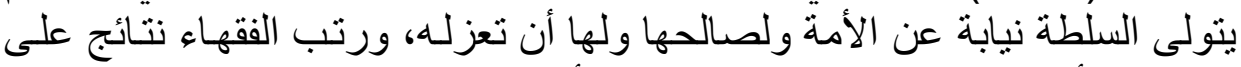

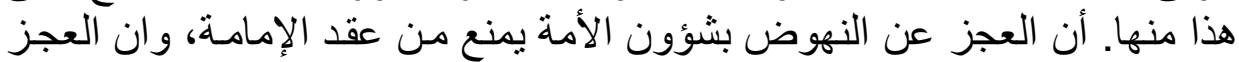

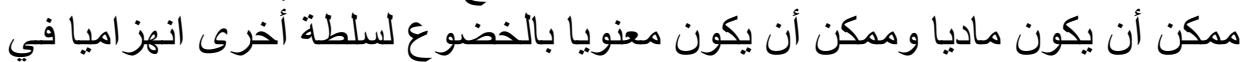

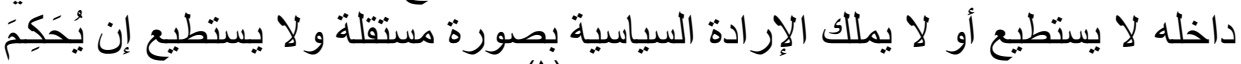

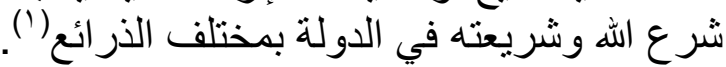

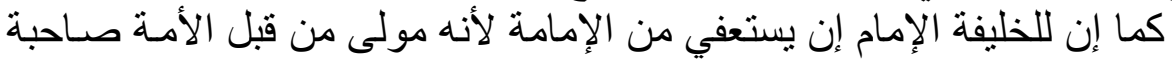

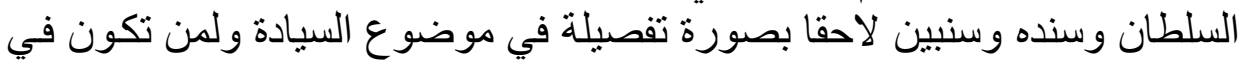

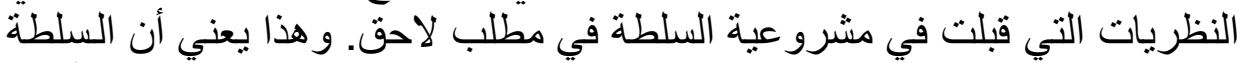

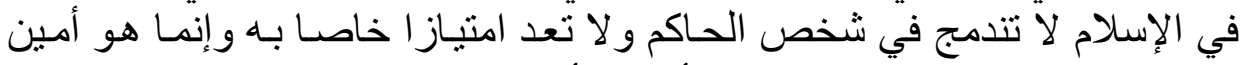

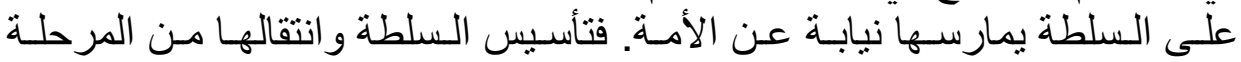

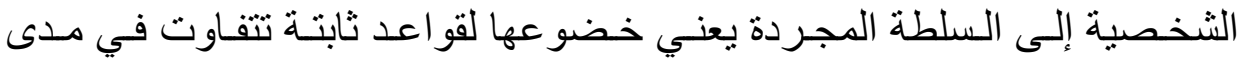

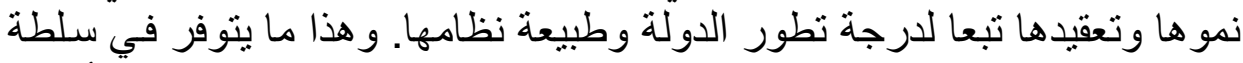

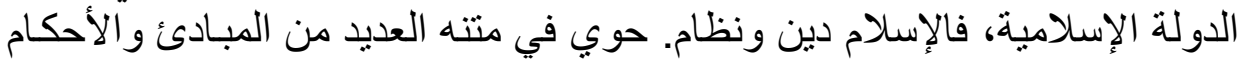

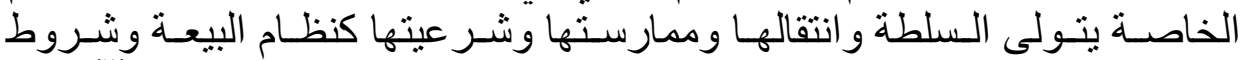

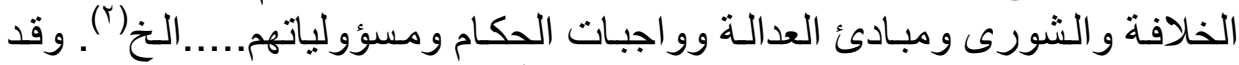

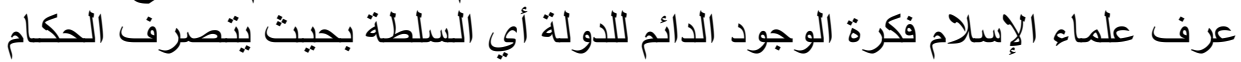

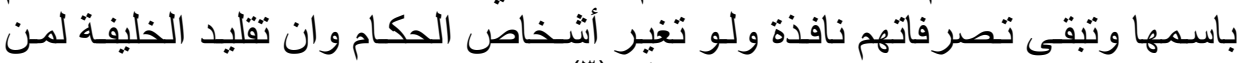

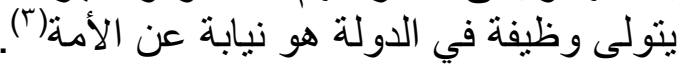

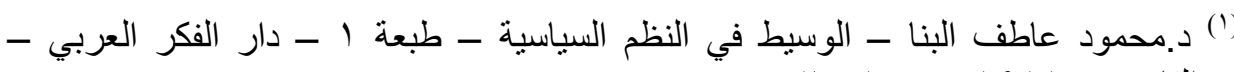

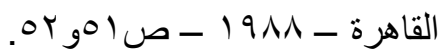

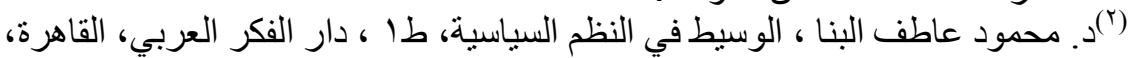

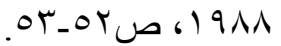

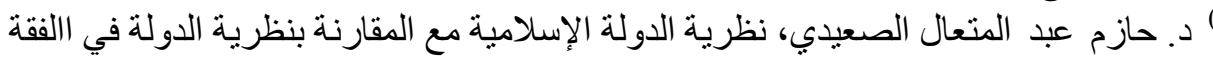

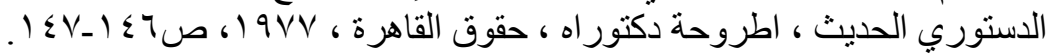




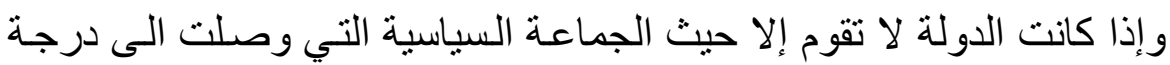

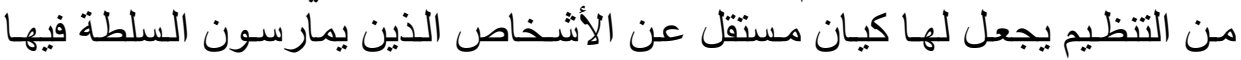

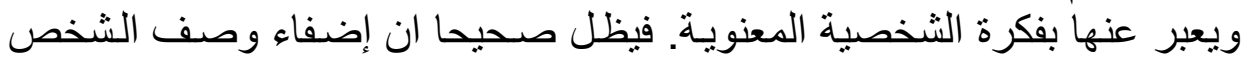

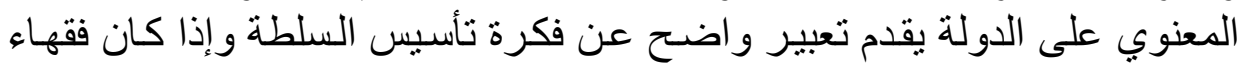

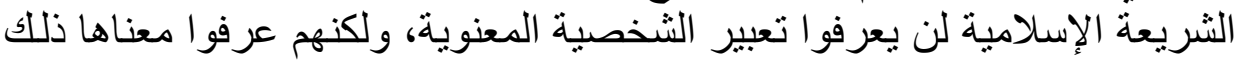

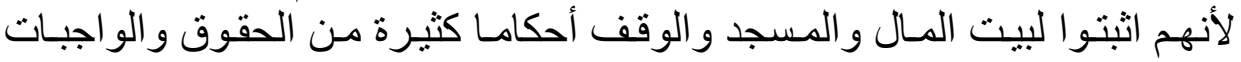

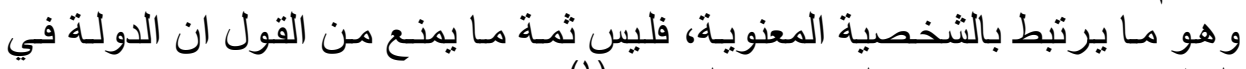

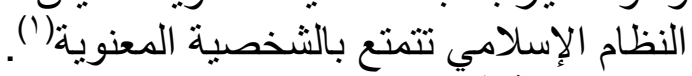

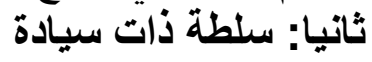
أن السلطة السياسية في الدولة ذات سيادة سيادة (سلطة عليا) وينطبق هذا الثيء

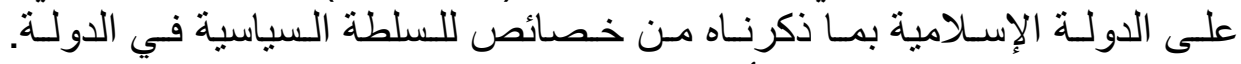

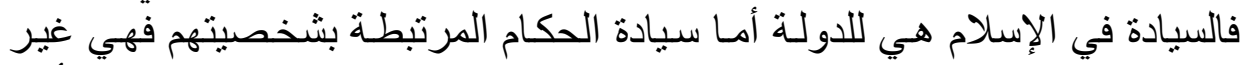

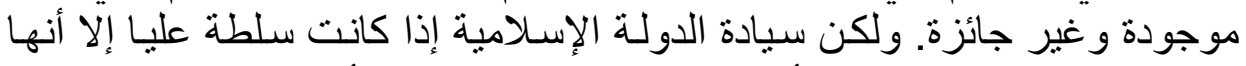

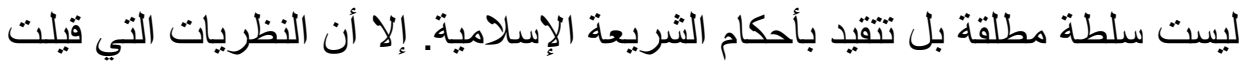

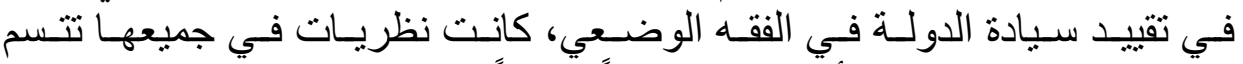

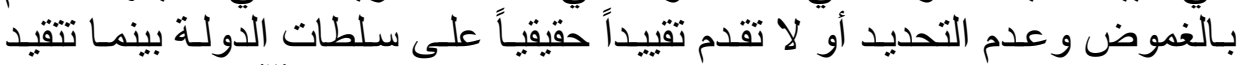
سلطة الدولة الإسلامية بالكثير من الأحكام ذات المصدر الفيد الإلهي (؟).

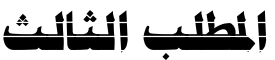

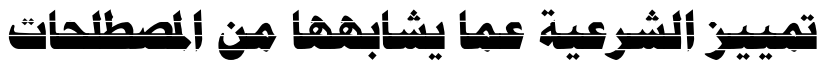

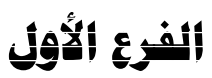

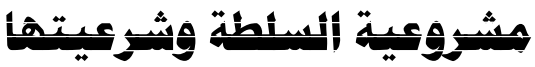

بعد أن بينا سابقا من انه لا يوجد تلازم بين مشرو عية السلطة وشر عيتها فهما

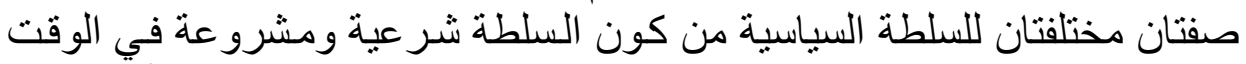

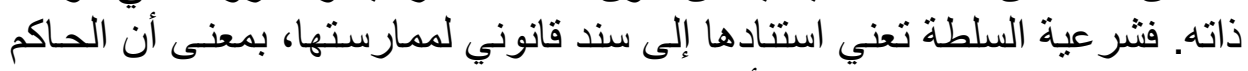

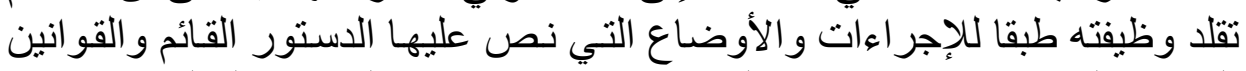

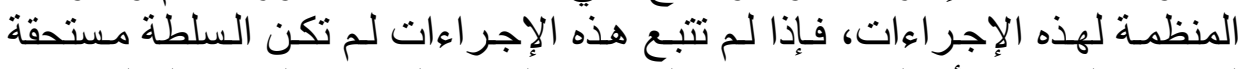

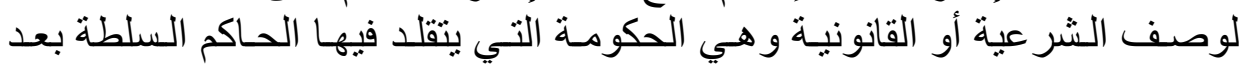

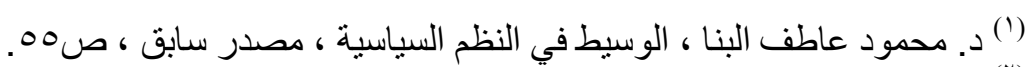

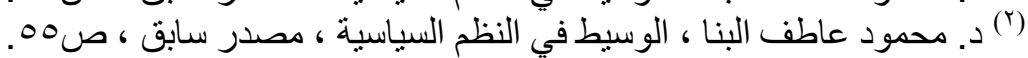




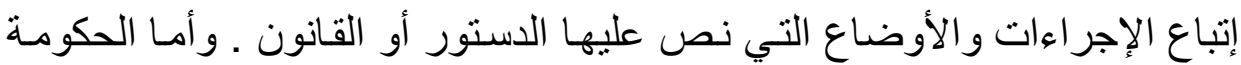

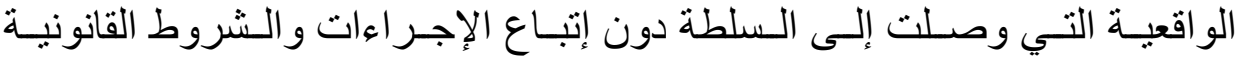

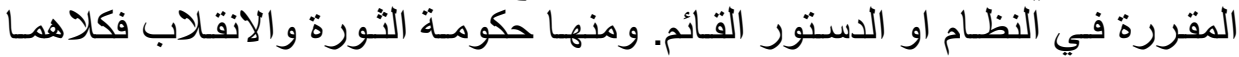

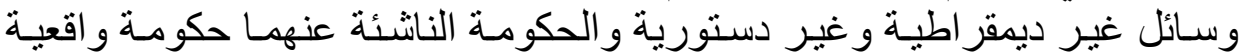

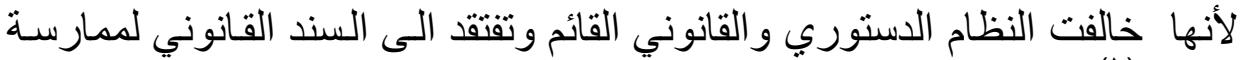
السلطة (')

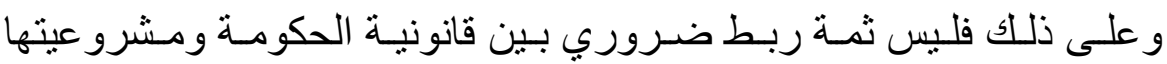

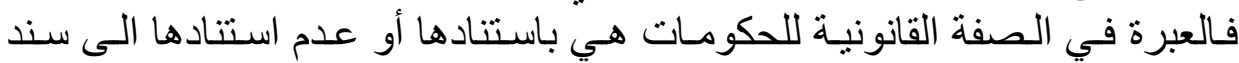

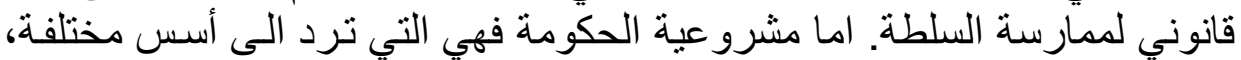

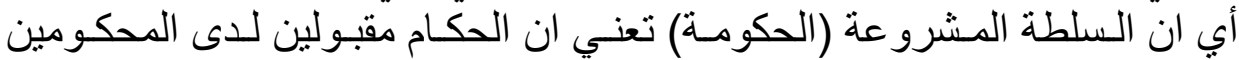

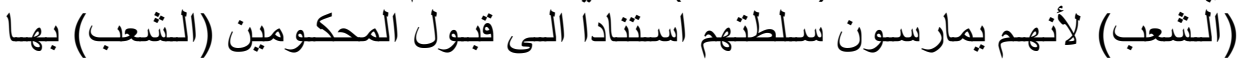

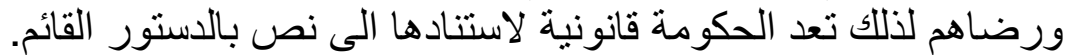

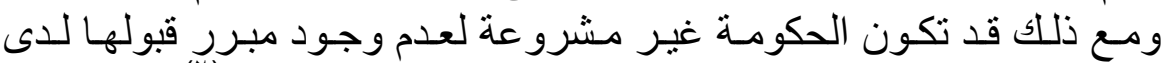

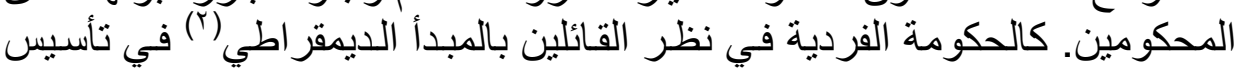

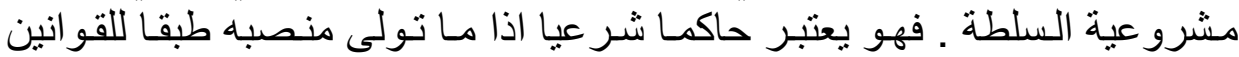

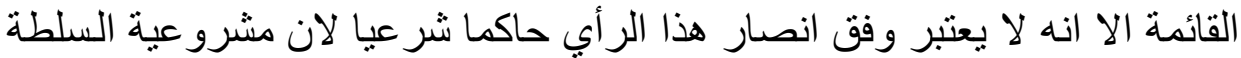

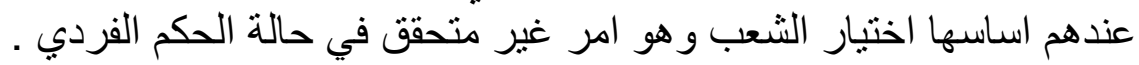

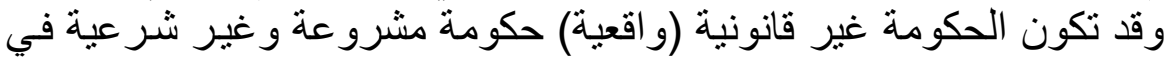

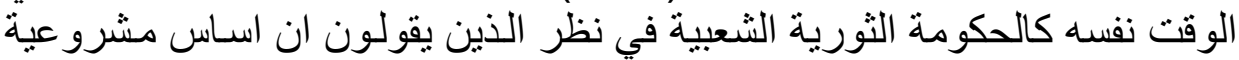

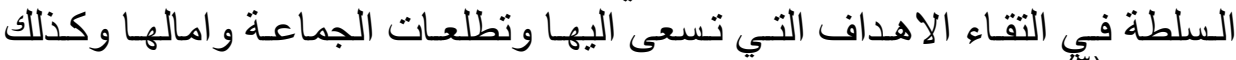

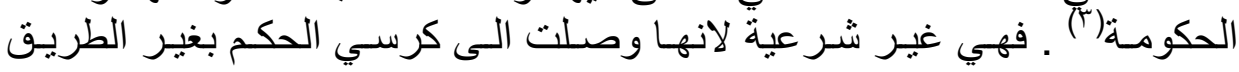

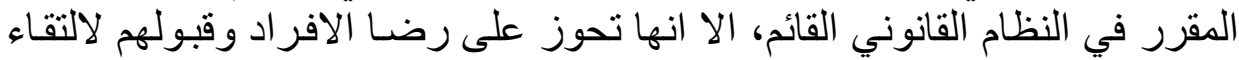
اهدافها مع اهدافهم ولذلك توصف الكون بالحكومة المشرو عة.

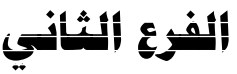

(') ،. حسين عثمان محمد عثمان ، النظم السياسية والقانون الدستوري ، الدار الجامعية ، مصر 10\&1911،

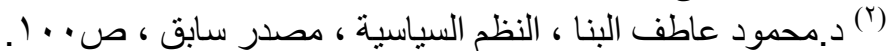

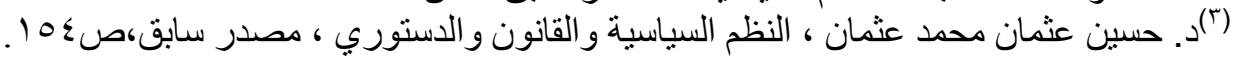




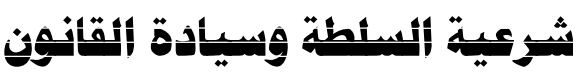

مبدأ شر عية السلطة يعني خضوع جميع السلطات الحاكمـة في الدولـة للقانون

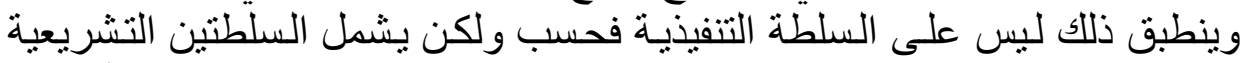
و القضائية كل ذلك بهدف حمايـة الافر اد في حقوقهم وحريـاتهم من تحكم أي من هذه السلطات.

اما مبدأ سيادة القانون فينبع عن فكرة سياسية تتعلق بتنظيم السلطات العامـة التهات

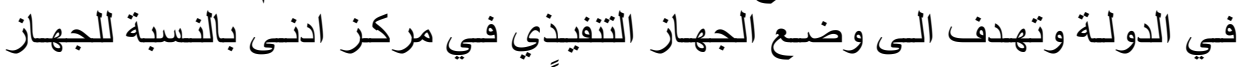

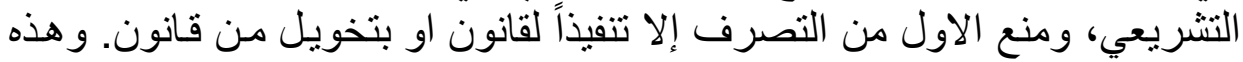

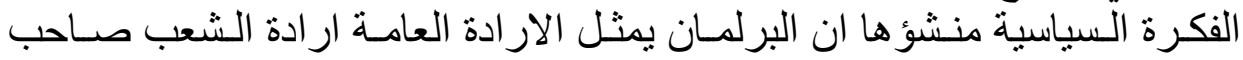

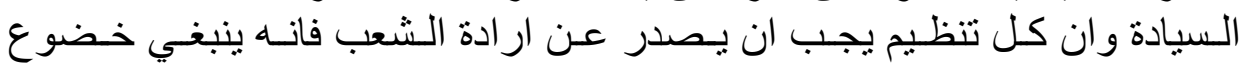

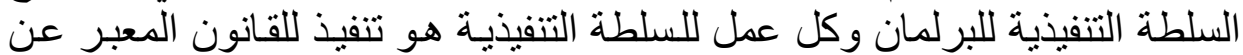
الار ادة العامة العلياً(').

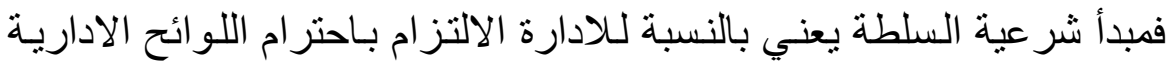

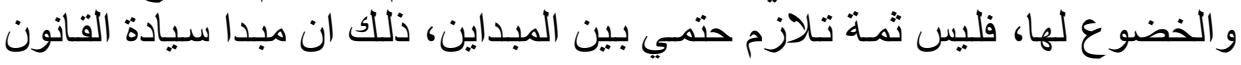

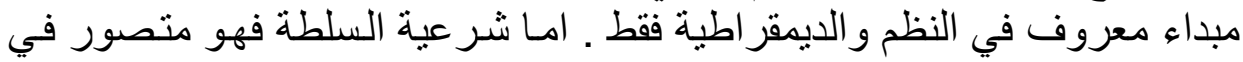

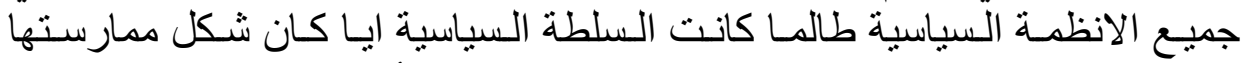

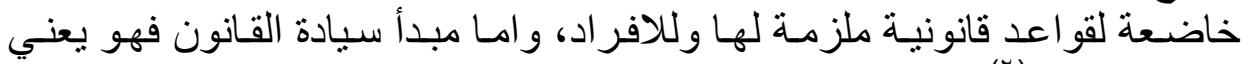

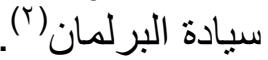

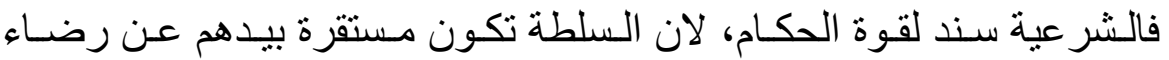

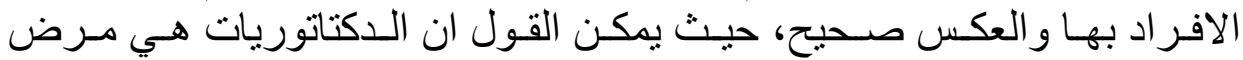

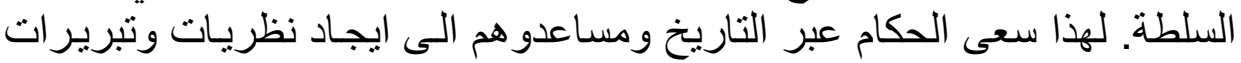

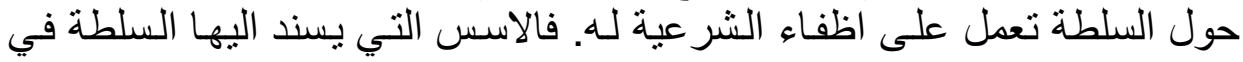

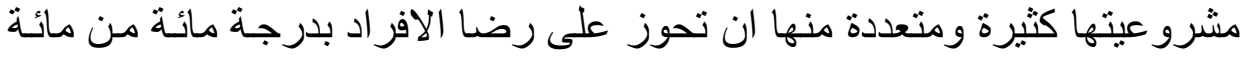

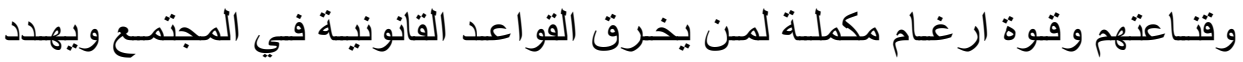
حريات وحقوق الافر اد.

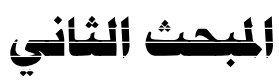

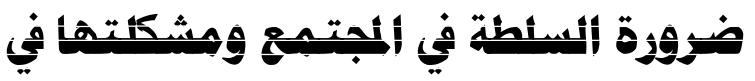

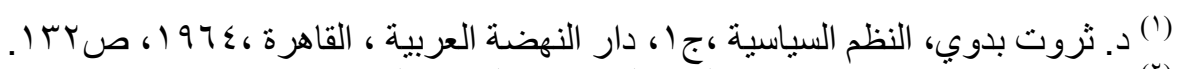

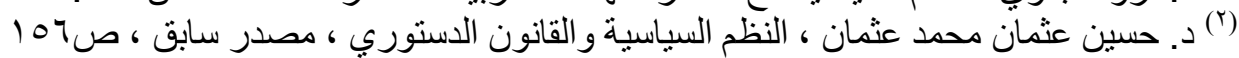




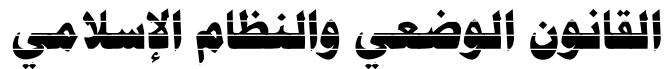

سـنتناول في هـا المبحـث در اسـة ضـرورة الـسلطة ومسكلتها في القـانون الوضعي و النظام الإسلامي في مطلبين

\section{Jgitit thif}

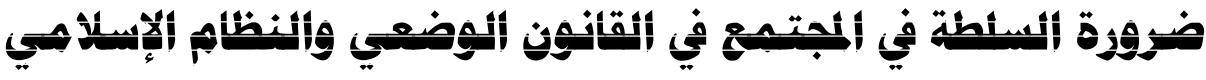

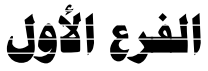

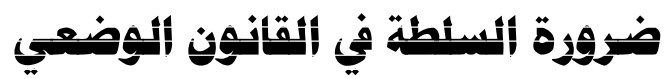

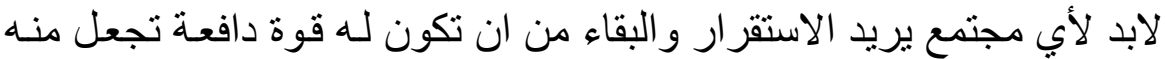

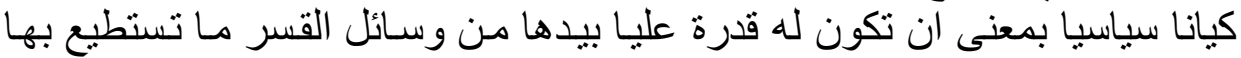

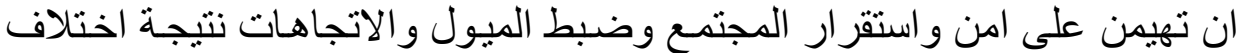

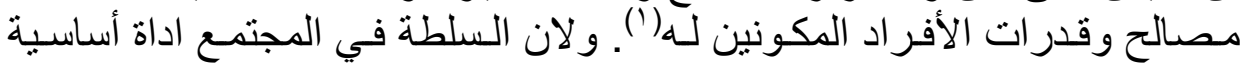

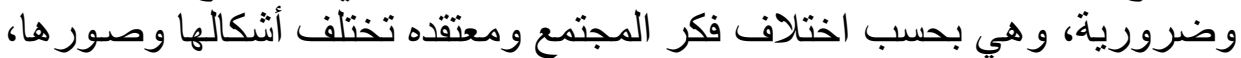
كما ان الأفر اد الذين يقضون وني على السلطة نسميهم بالحكام.

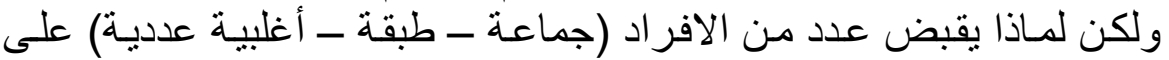

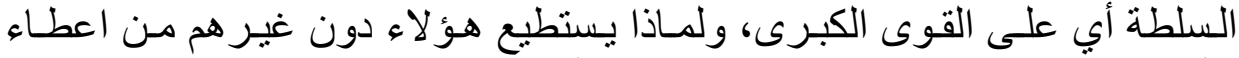

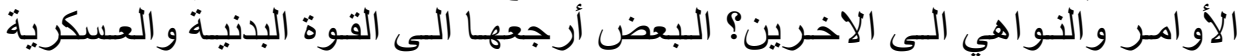

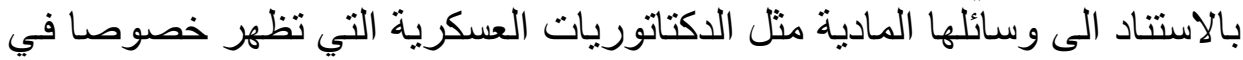

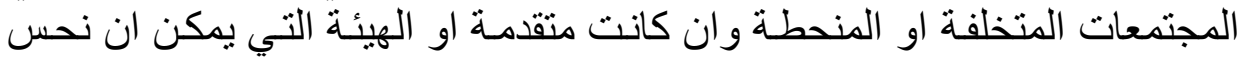

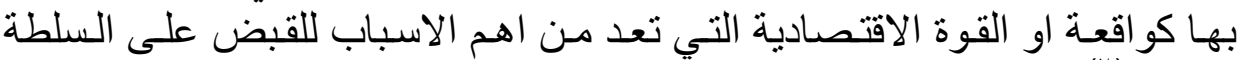

وتملكها (r).

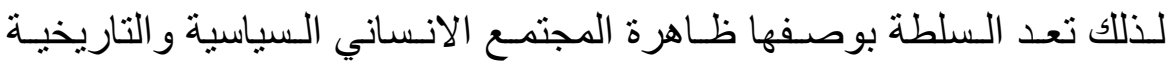

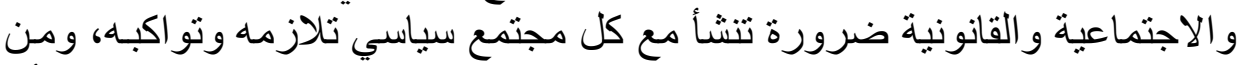

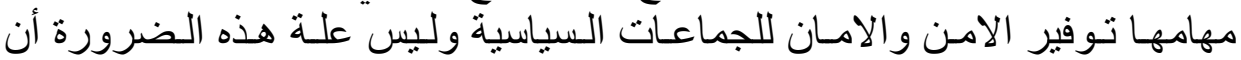

(')Burdeau : Traite de science politique zem, ed , paris . 1966. أنشار إلبه د. صبحي غبدة سعبد ، شر عية السلطة و النظام في حكم الإسلام ، در اسة مقارنة دار

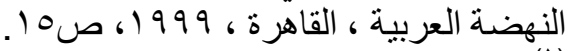

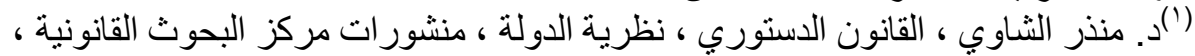

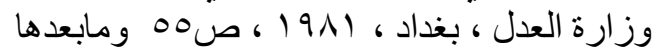


السلطة هي التي تخلق النظام، ولكن تكمن في تعدد المصالح وتضاربها والتي

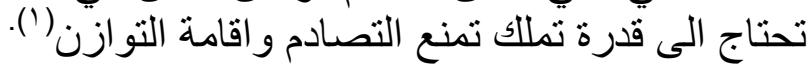

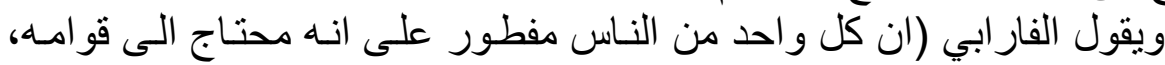

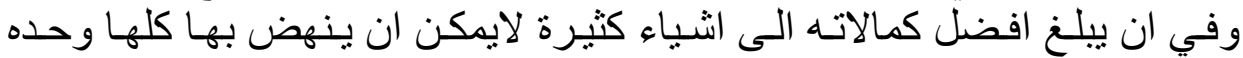

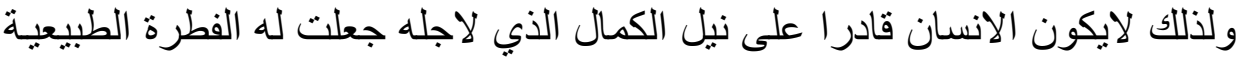

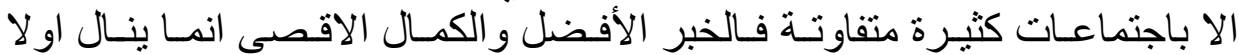

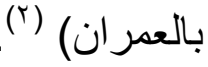
ويقول ابن خلدون في مقدمته (ان الاجتماع الإنساني ضرورة فانس الانسانسان مدني

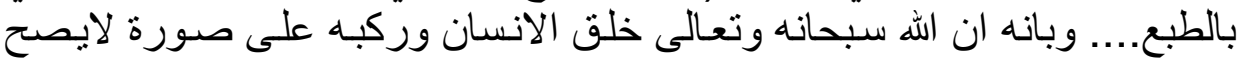

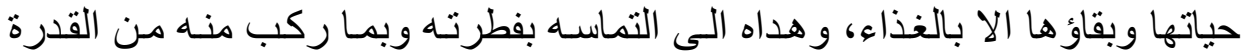

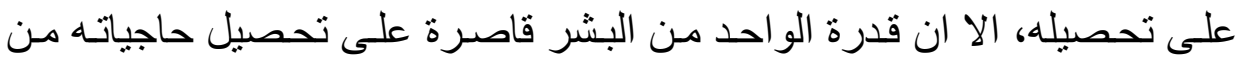

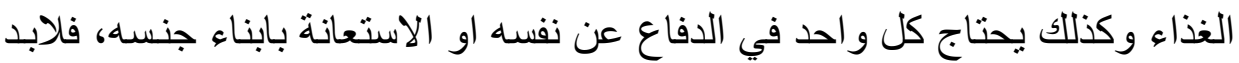

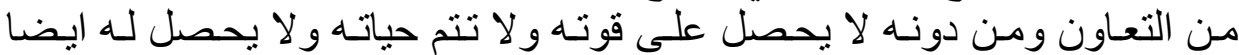

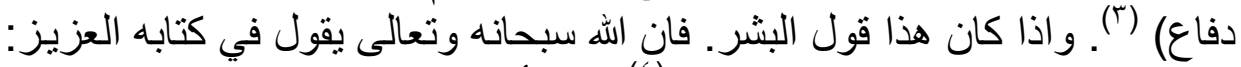

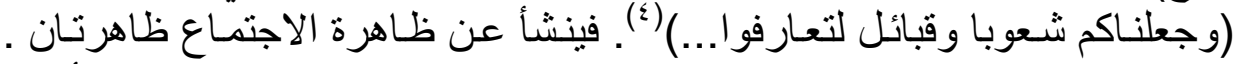

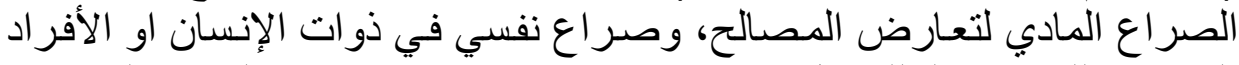

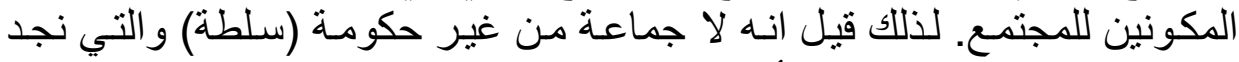

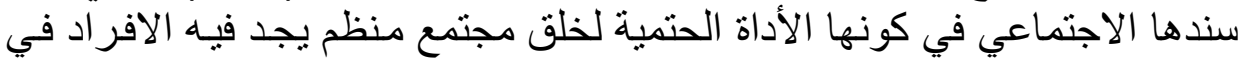

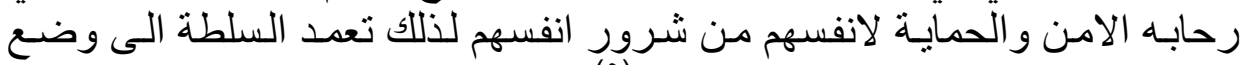

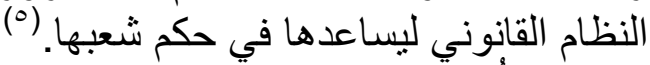

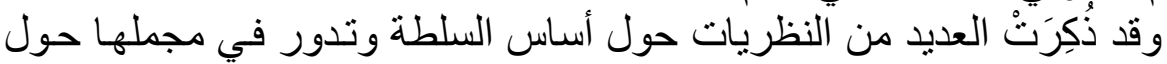

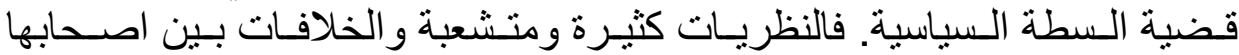

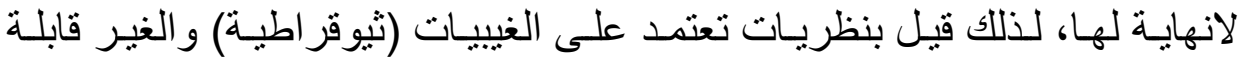

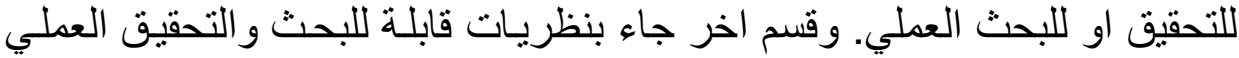

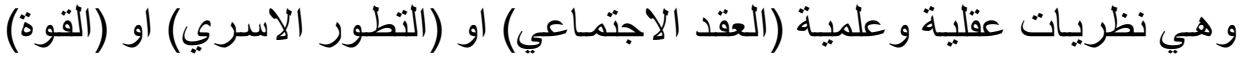

(r) (َ). صبحي عبدة سعيد ، السلطة و الحرية في النظام الإسلامي ، در اسة مقارنة ، دار الفكر

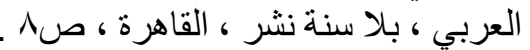

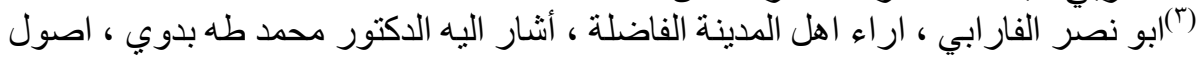

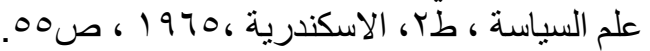

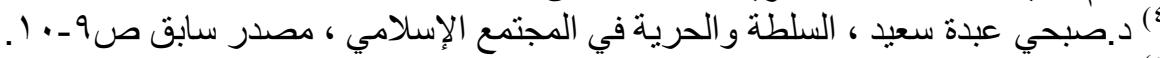

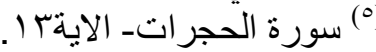

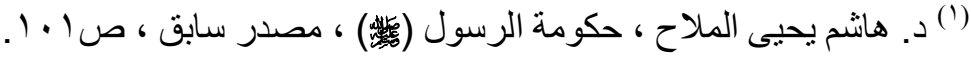


او (العو امل التاريخية) ولكن أي وصف لهذه النظريات التي قال بها الفقه لايعني

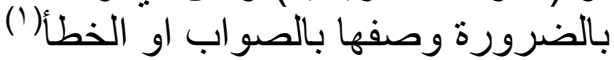

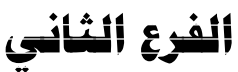

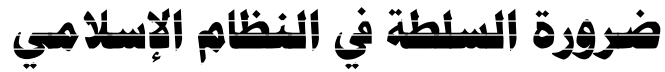

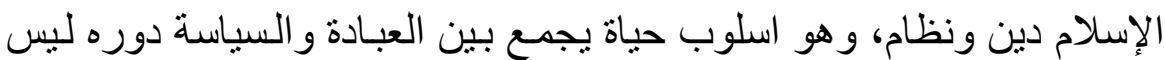

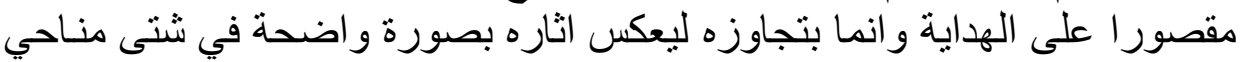

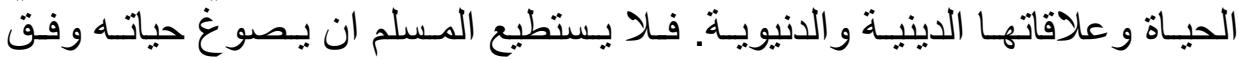

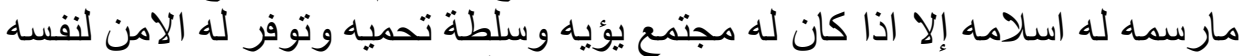

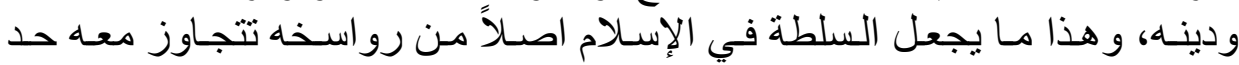

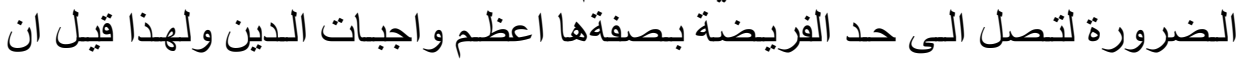

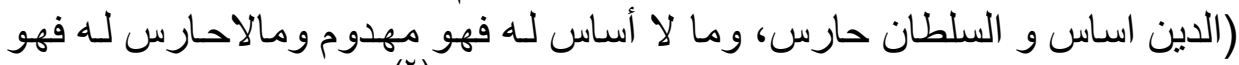

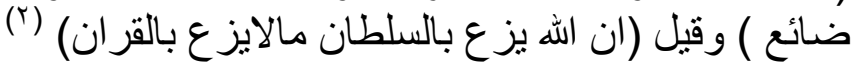

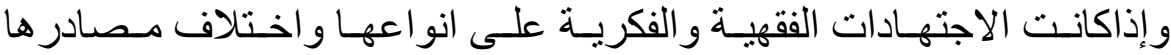

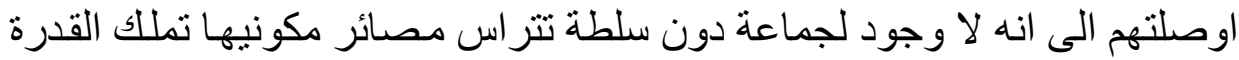

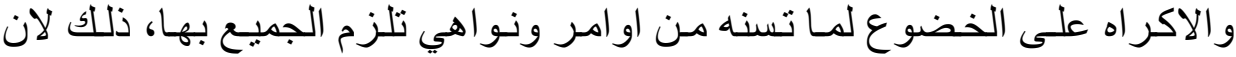

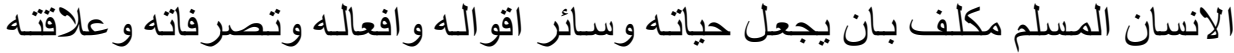

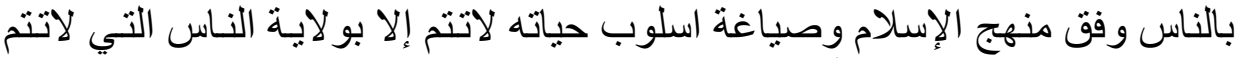

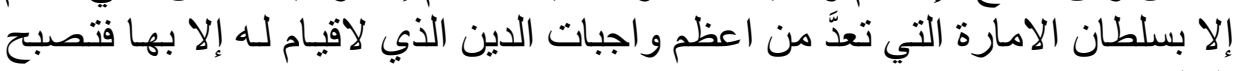

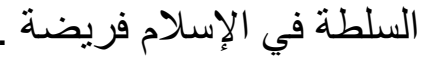

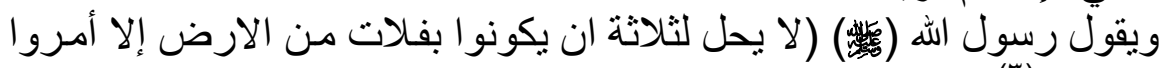

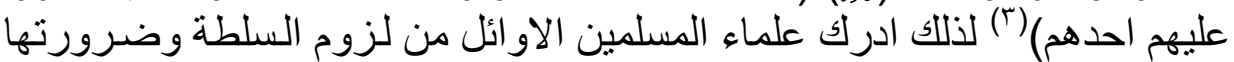

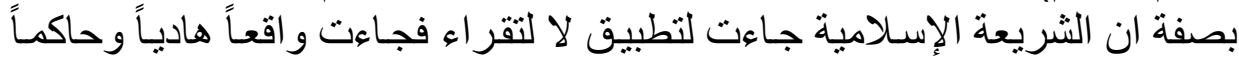

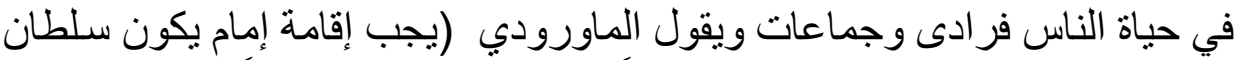
الوقت وزي عيم الامة ليكون الدين محروساً بسلطانه و السلطان جارياً على سنى الدين

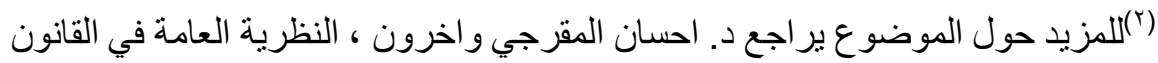

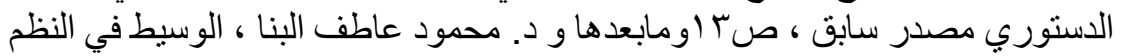

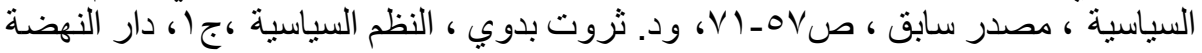

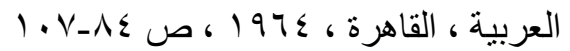
(") (الد. صبحي عبده سعيد ، السلطة السياسية في المجتمع الإسلامي ، وكالة الأهر ام للتوزيع

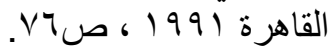
(') مسند الإمام احمد ، عن عبد الله بن عمر ، رواه مسلم 


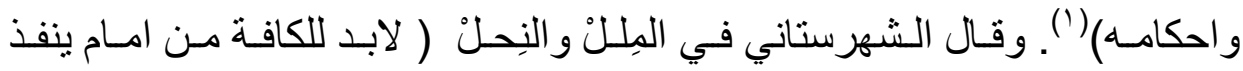

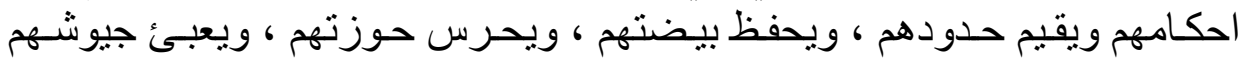

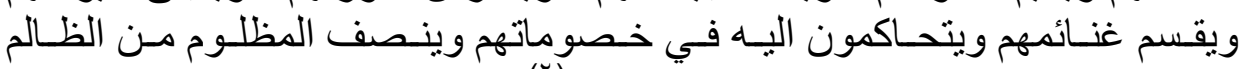

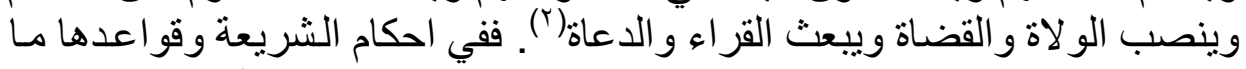

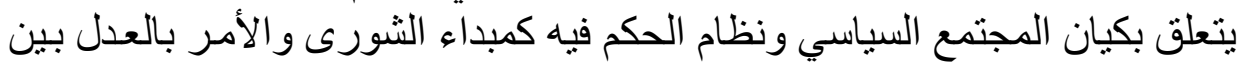

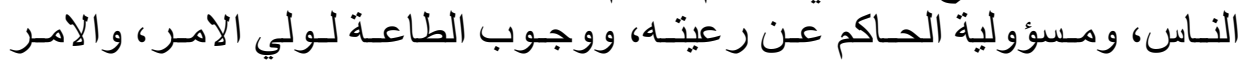

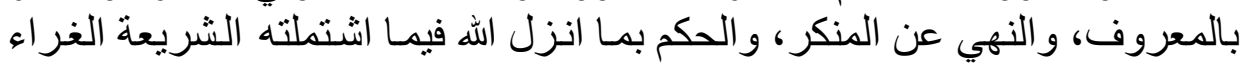
في شتى مناحي الحياة.

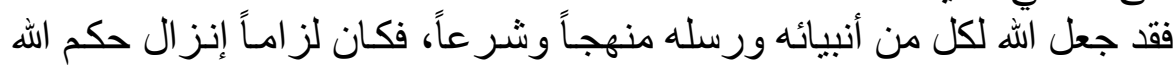

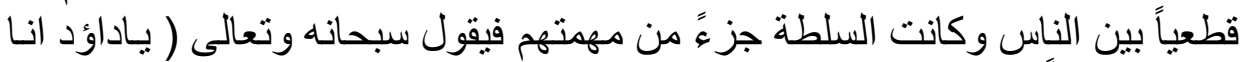

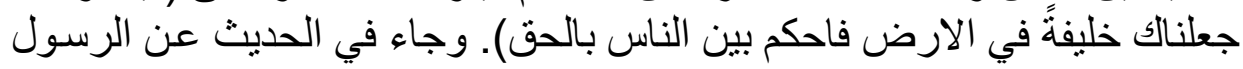

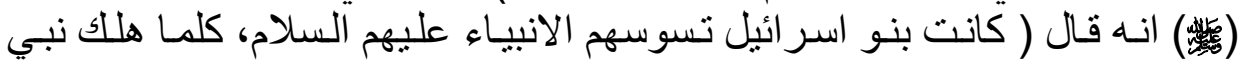

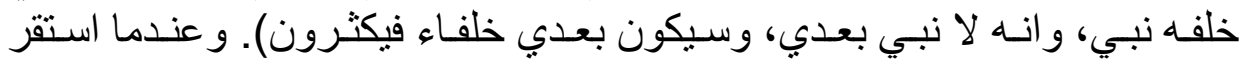

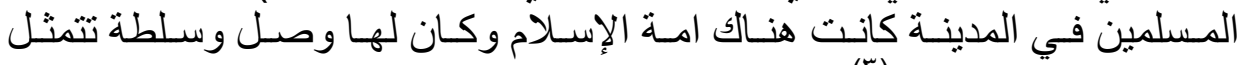

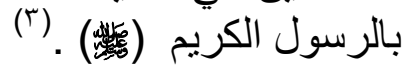

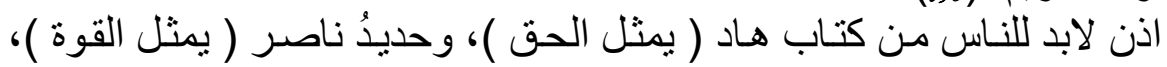

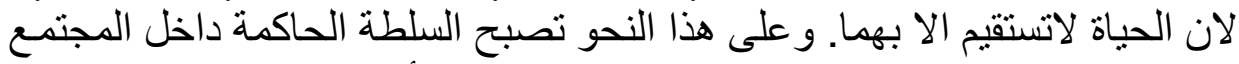

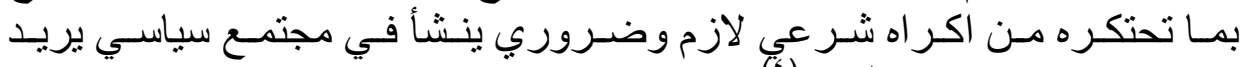

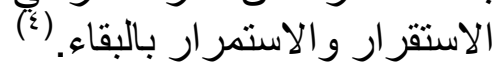

\section{itifi

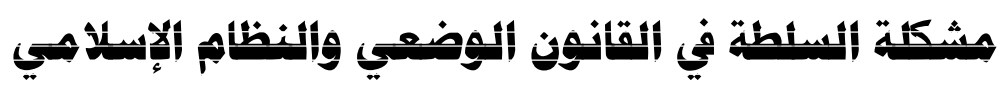

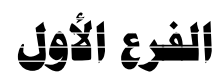

(r) الماوردي - ابو الحسن علي بن محمد بن حبيب البصري الماوردي ـ الأحكام السلطانية

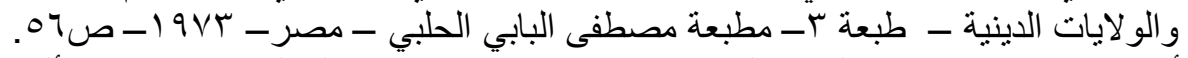

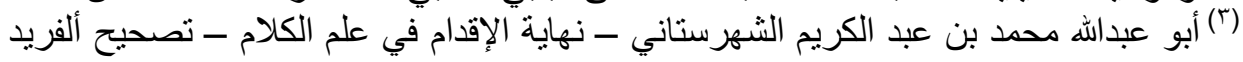

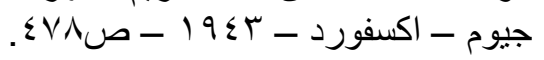

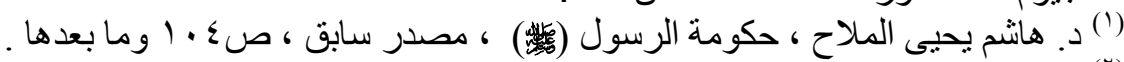

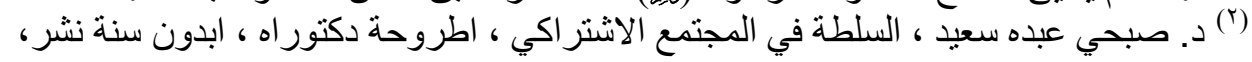

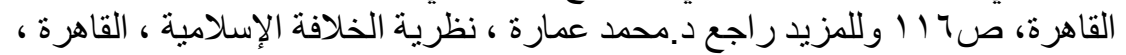
ص74. 


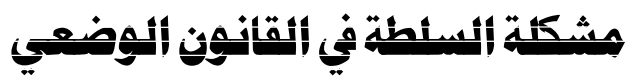

يعرف البعض المجتمع السياسي بانه عبارة عن جمعية يكون انتمـاء الاعضاء الاعضاء

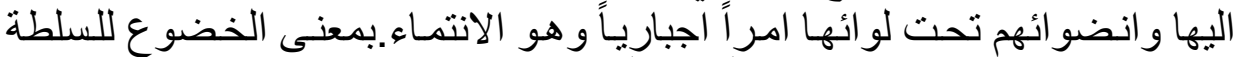

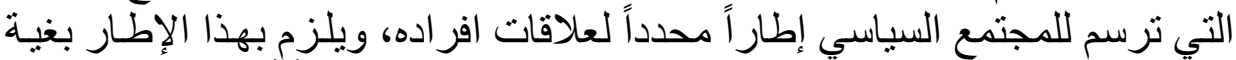

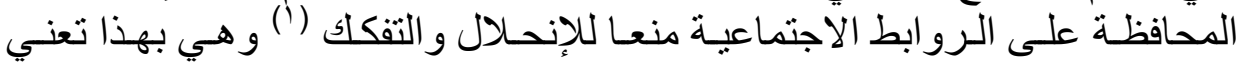

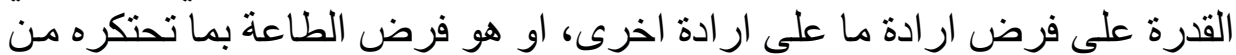

ولكن مـاحجم هذه السلطة تجـاه الفرد ، و هنا تضحى المسألة مسألة سياسبة

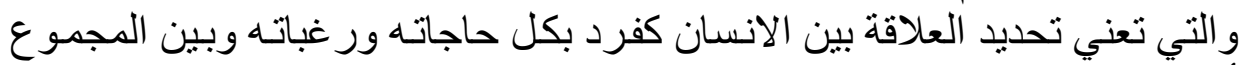

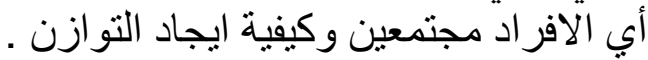

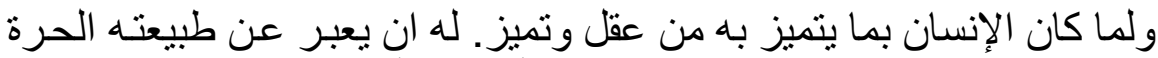

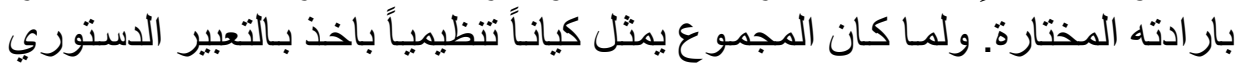

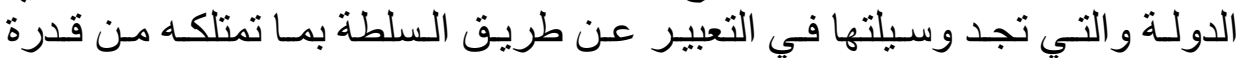

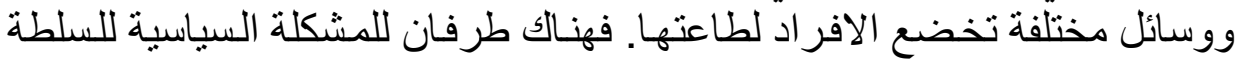

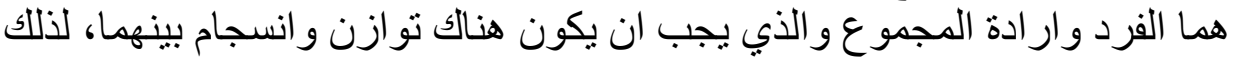

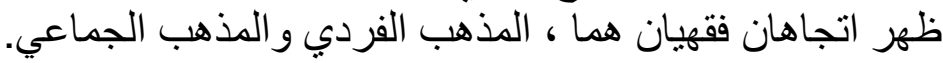

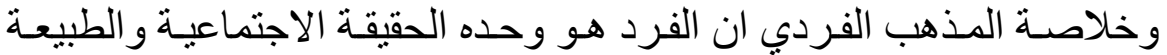

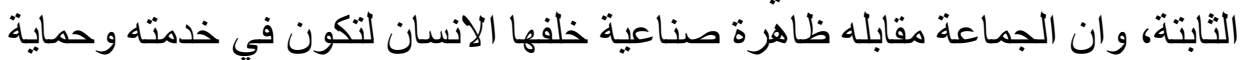

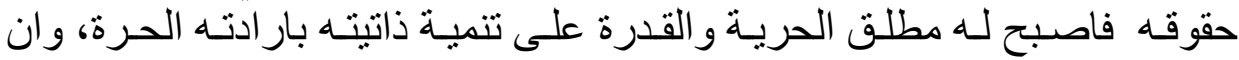

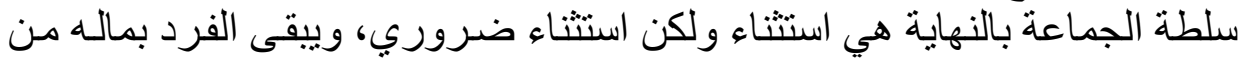

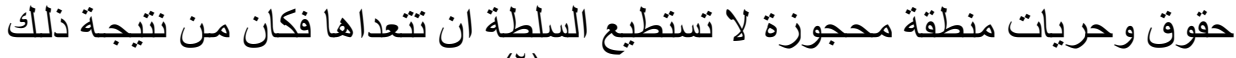
ان طغى سلطان الفرد وتفشي الاثرة و الانانية.

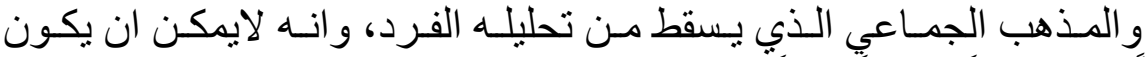

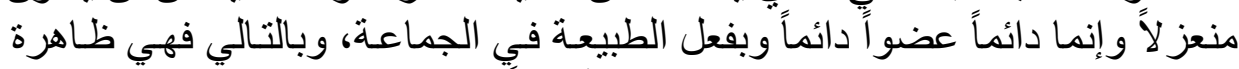

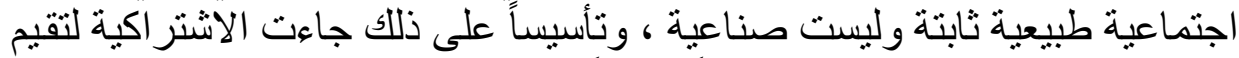

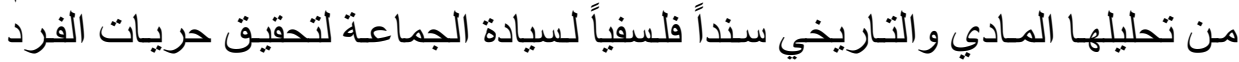

(5) د. محمود عاطف البنا ، الوسيط في النظم السياسية ،طا، دار الفكر العربي، القاهرة،9191، صTri IT) (1) د.صبحي عبدة سعيد ، السلطة السياسية في الدجتمع الإسلامي ، مصدر سابق ، ص/Y I . 
و أعطيت السلطة صلاحيات و اسعة للتنخل في مختلف نشاط الفرد، أي انه لاتوجد

نقاط محجوزة من أمام السلطة.

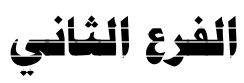

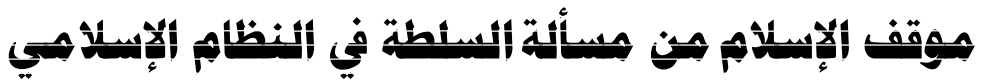

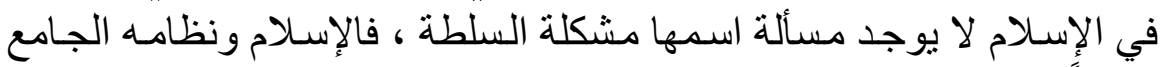

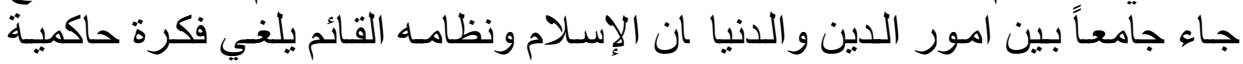

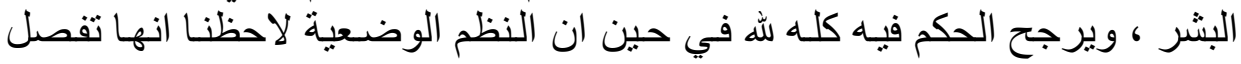

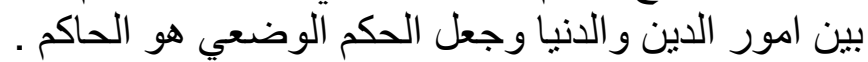

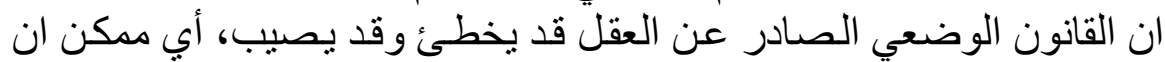

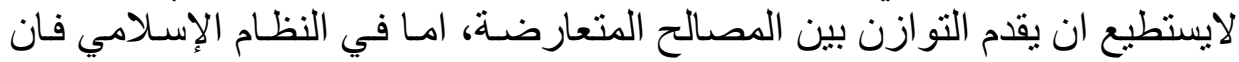

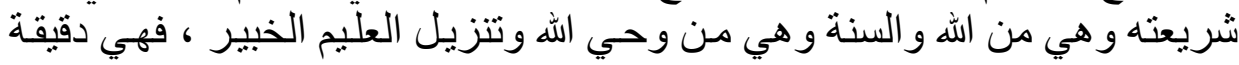

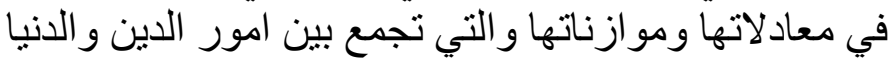

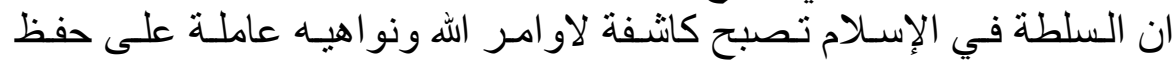

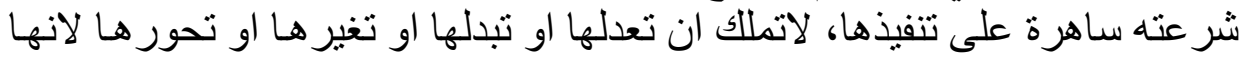

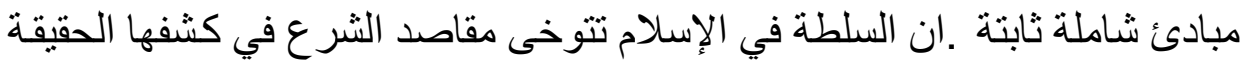

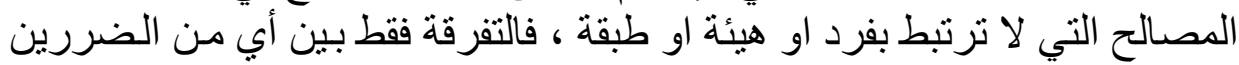

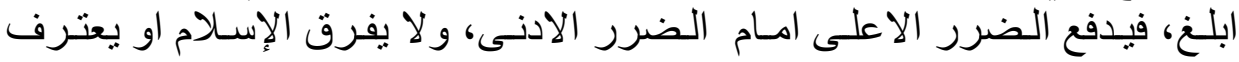

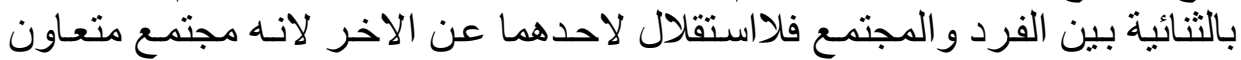

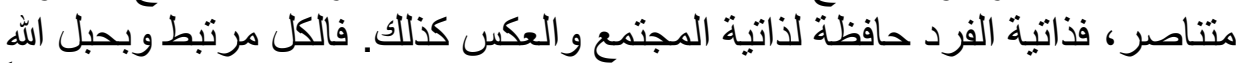

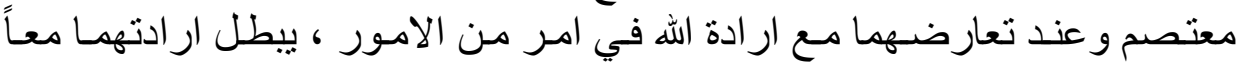

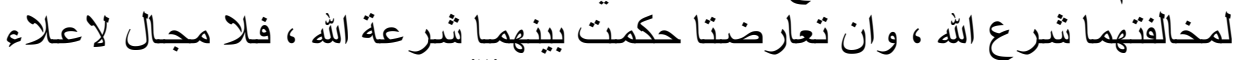

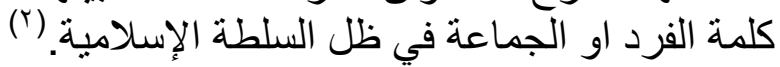

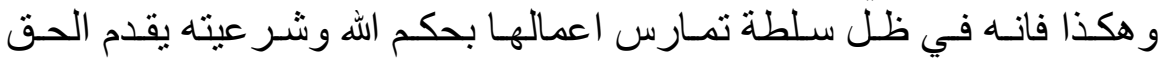

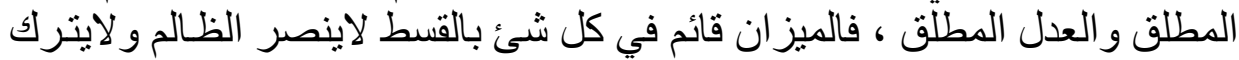

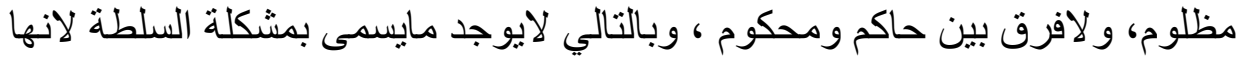

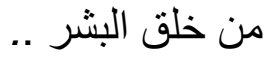

\section{أبثىث}

$$
\begin{aligned}
& \text { (Y) المصدر السابق نفسه صس ب ا و وما بعدها. }
\end{aligned}
$$

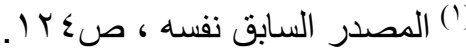




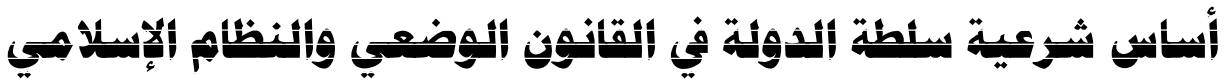

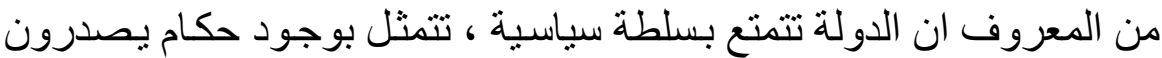

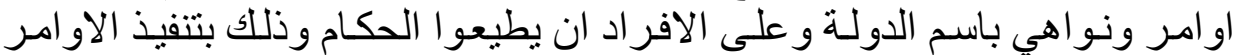

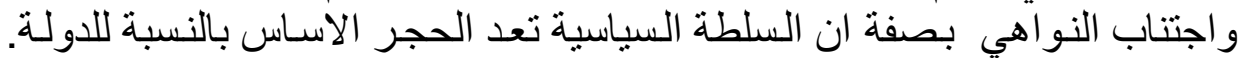

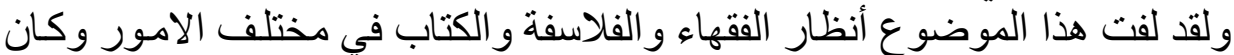

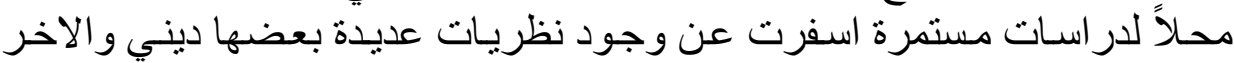

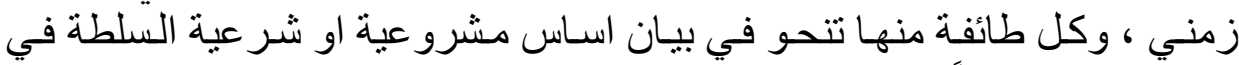

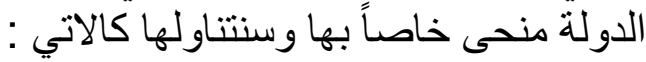

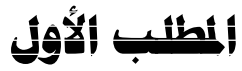

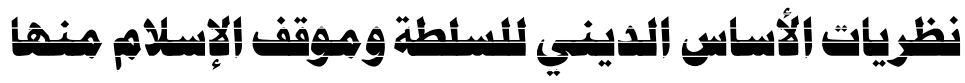

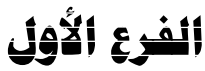

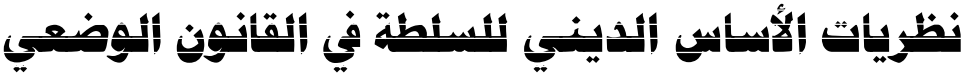

$$
\text { أولاً: نظرية الطبيعة الإلهية للحكام }
$$

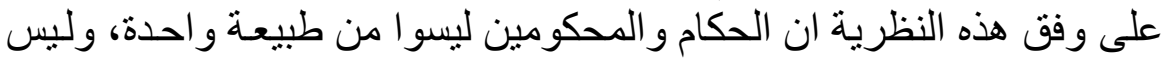

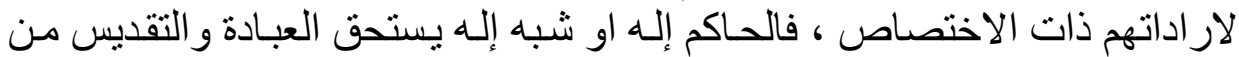

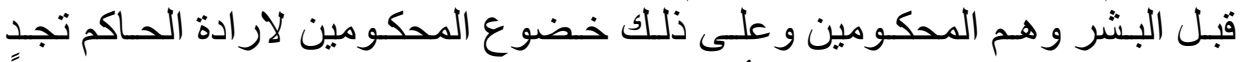

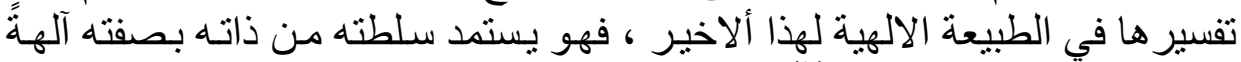

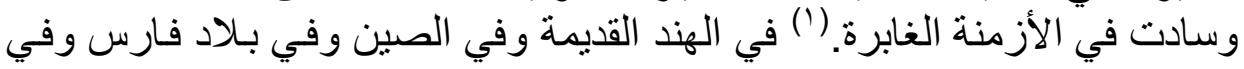

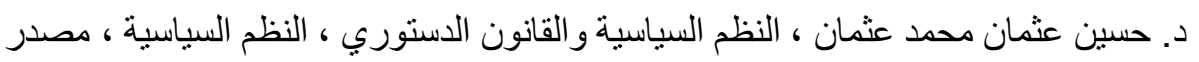

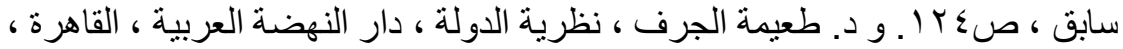

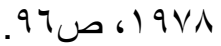




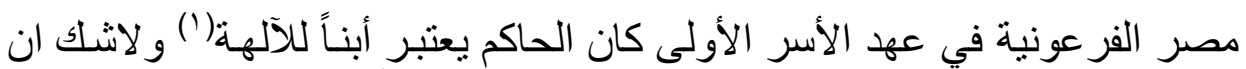

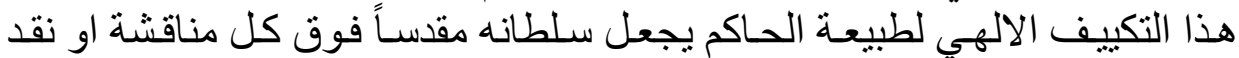

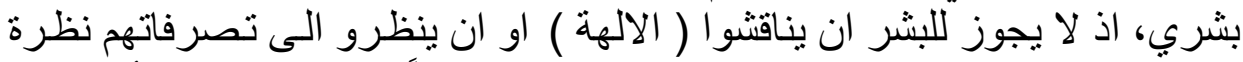

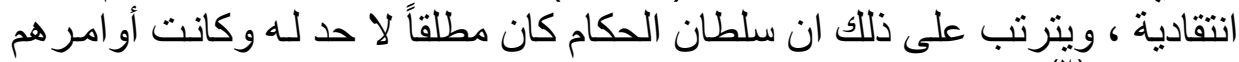

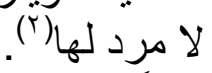

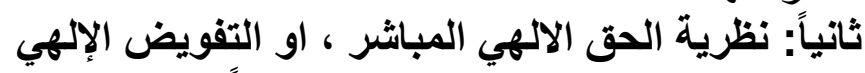

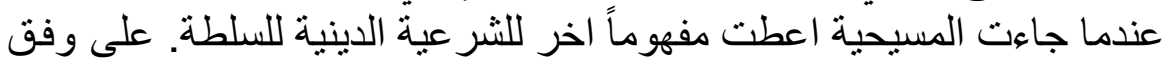

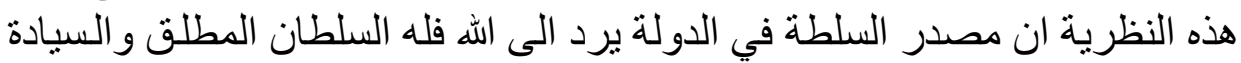

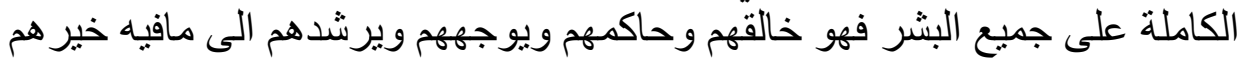

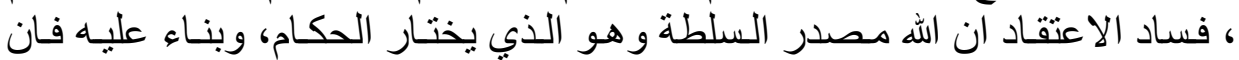

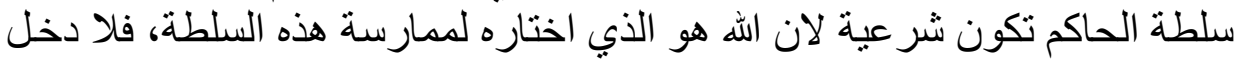

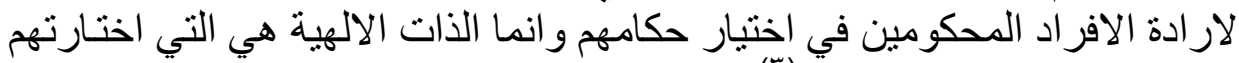

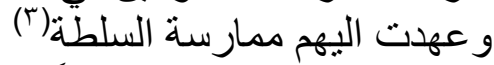

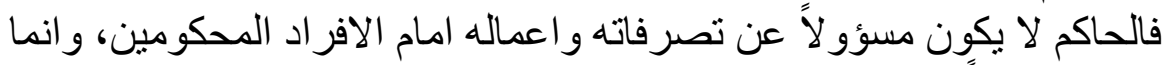

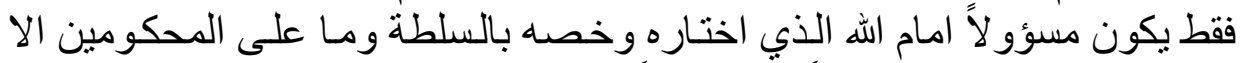

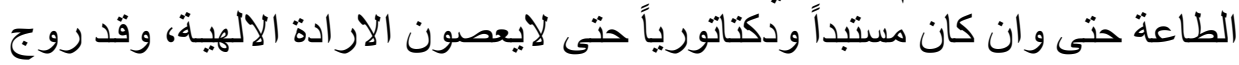

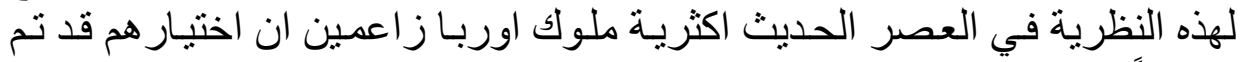

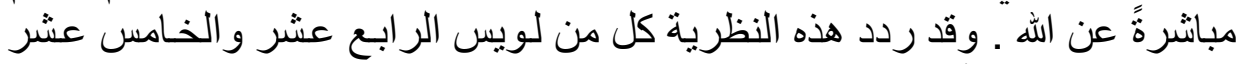

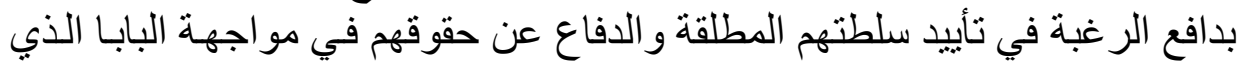

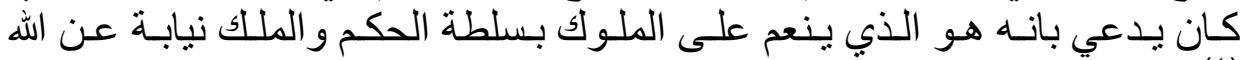

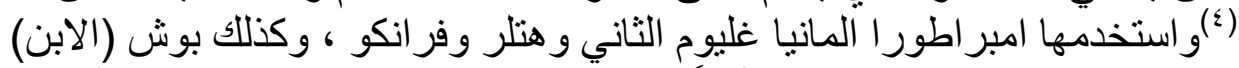

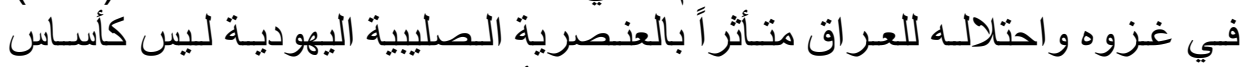

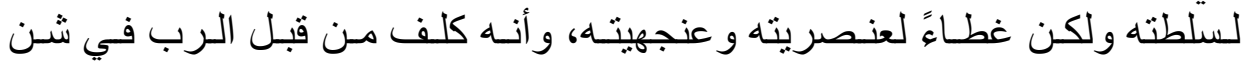

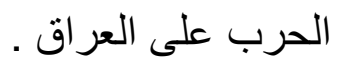

(r) ديحيى الجمل - حصاد القرن العشرين في علم القانون - طبعة ا ـ دار الثروق -

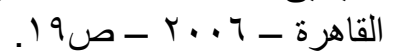

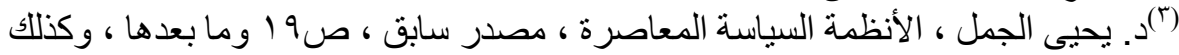

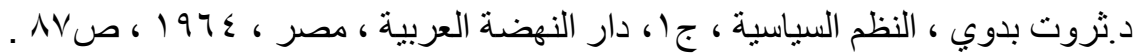

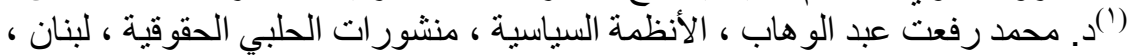

$$
\text { (r) }
$$

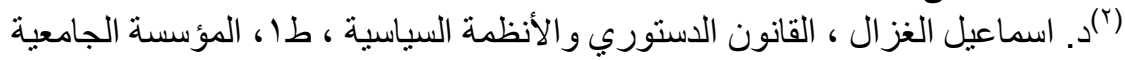

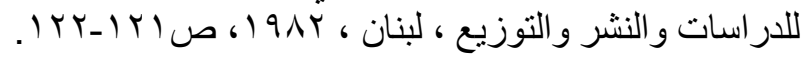




\section{ثالثاً: نظرية الحق الإلهي الغير مباشرة}

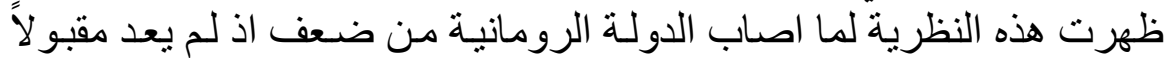

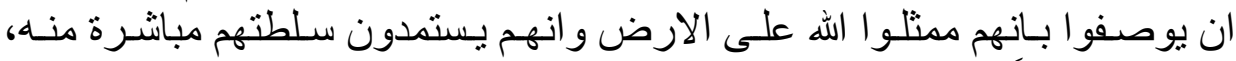

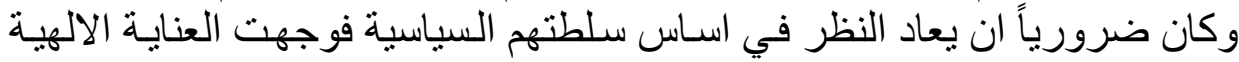

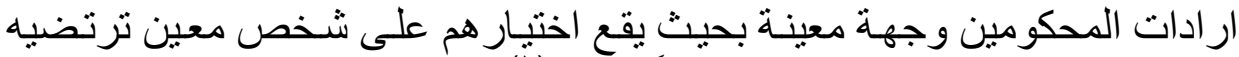

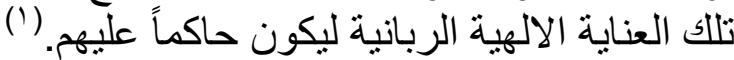

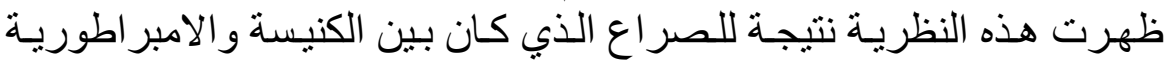

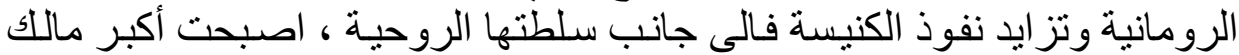

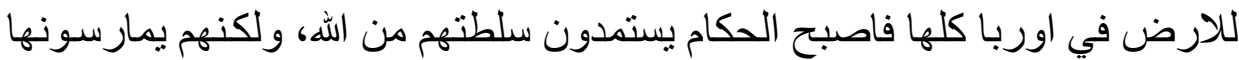

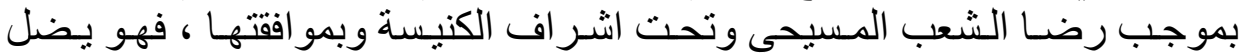

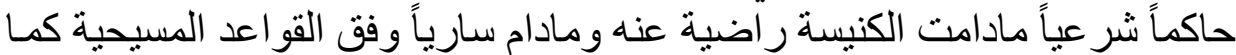

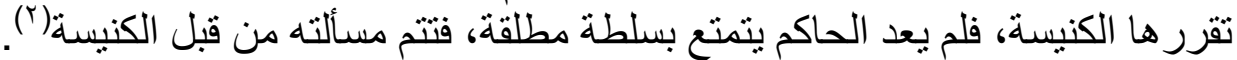

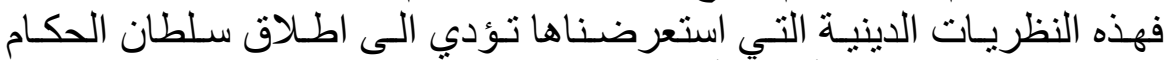

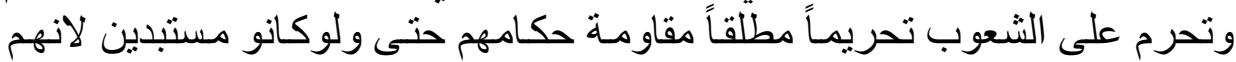

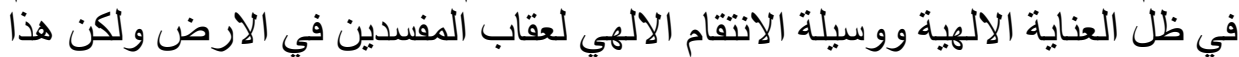

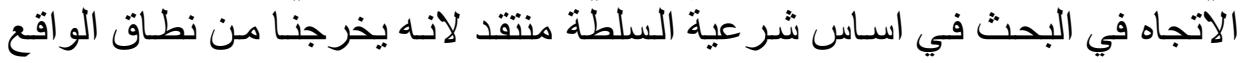

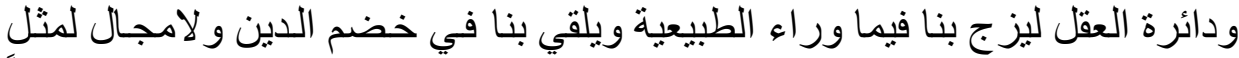

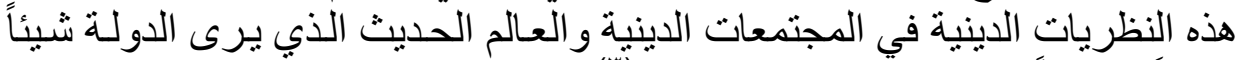

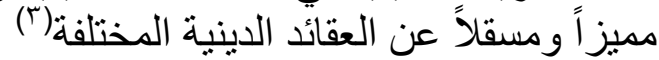

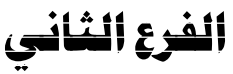

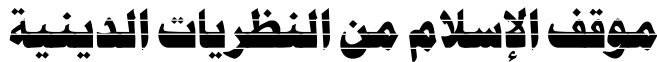

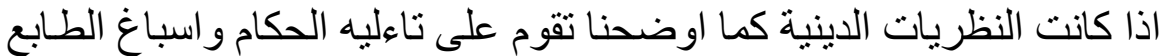

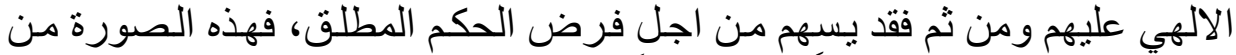

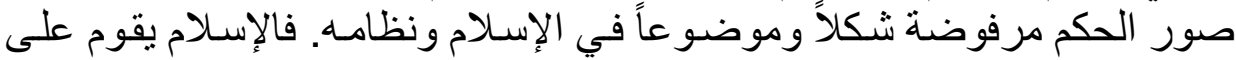

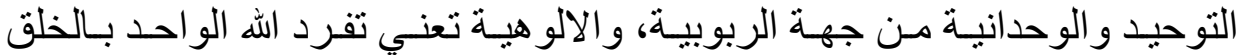

(r) (1)

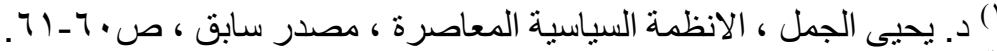

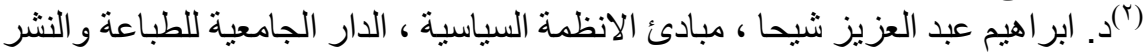

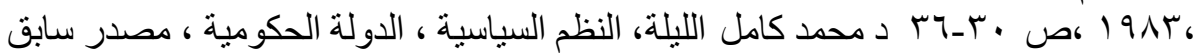




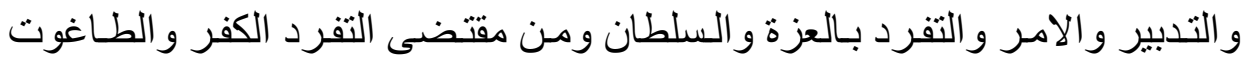

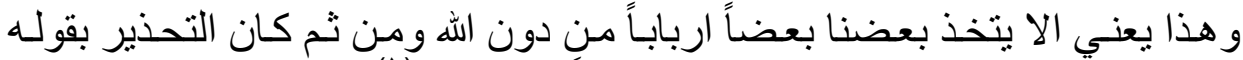

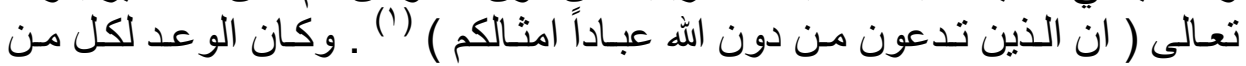

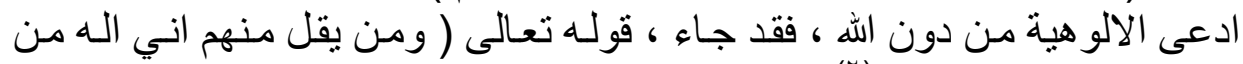

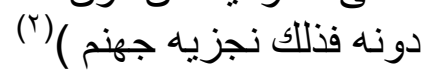
فقضية التوحيد محسومة منذ الازل فما كان لبشر من عظم شـأنه و علا قدره

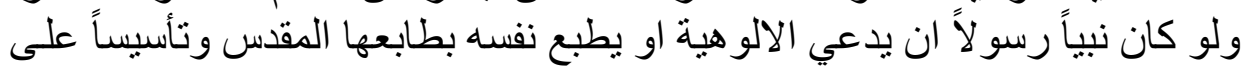

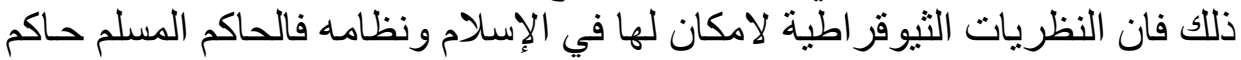

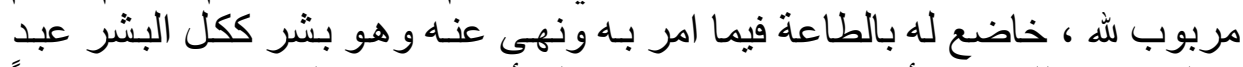

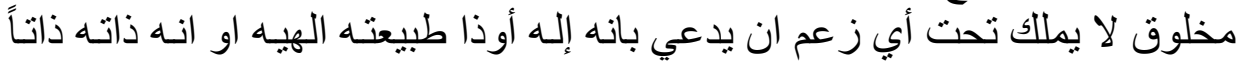

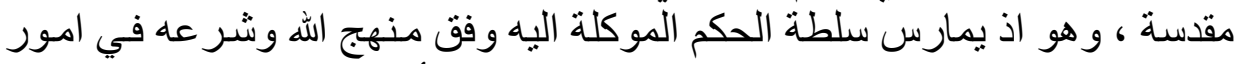

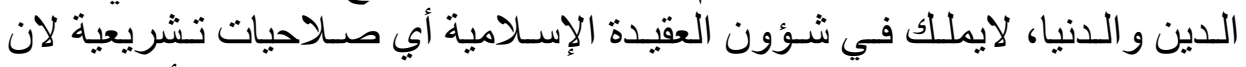

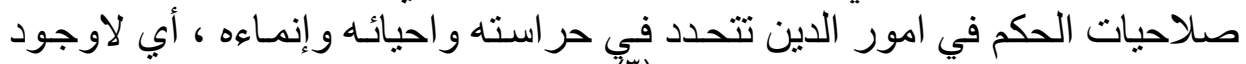

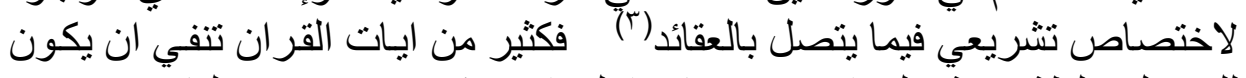

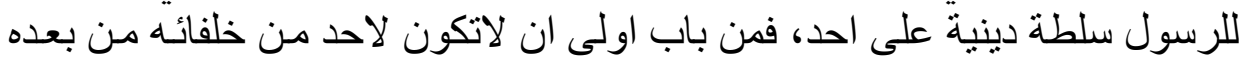

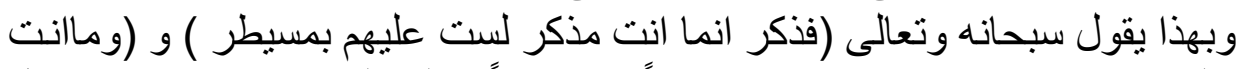

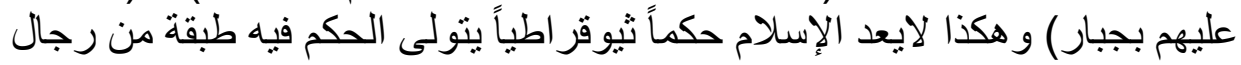

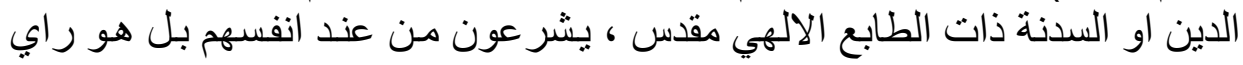

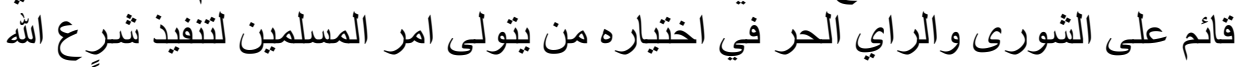

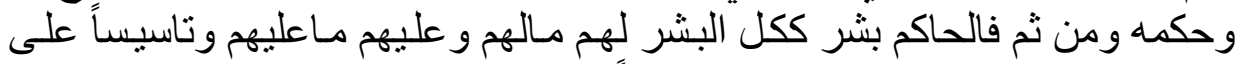

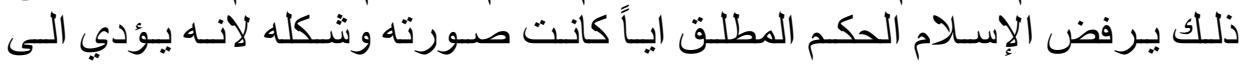
الاستبداد و التعالي على المحكومين لان الحم الحكام ليسو البمعصو مين.

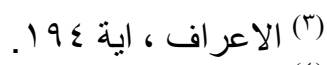

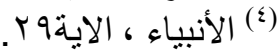

(') د. صبحي عبده سعيد ، شرعية السلطة و النظام في حكم الإسلام ، مصدر سابق ، ص بــrس. 
فالحساكم في الإسـلام ليس كالبابـا في الكنيسة الكاثوليكيـة لـه حق التشريع في التهي

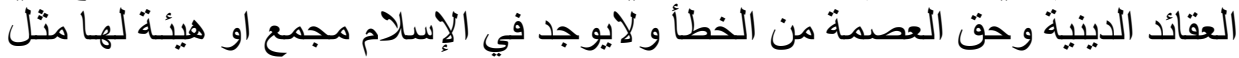

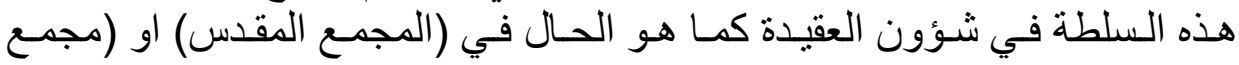

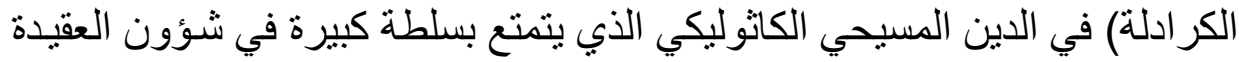

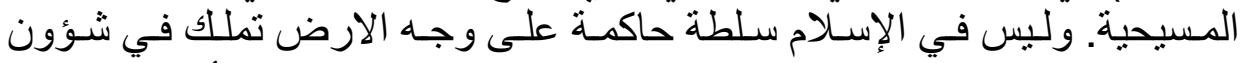

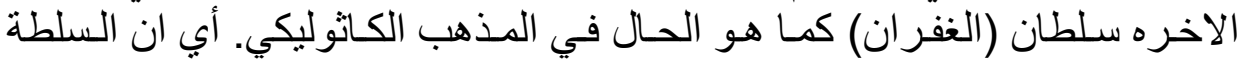

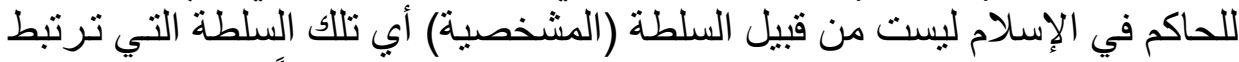

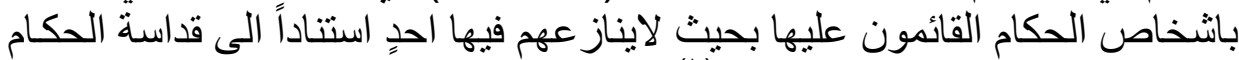

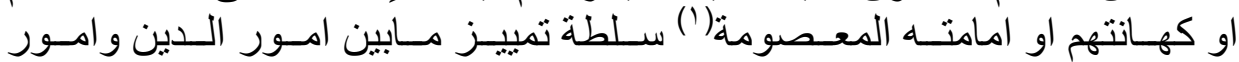

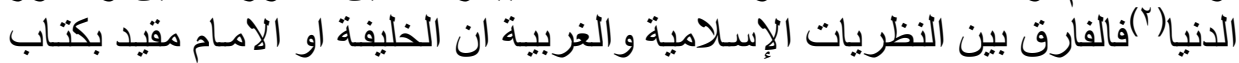

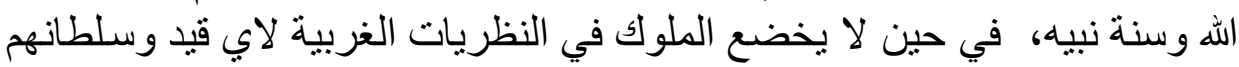
مطلق غير محدد .

\section{|}

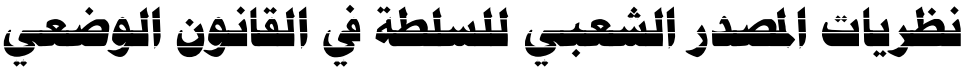

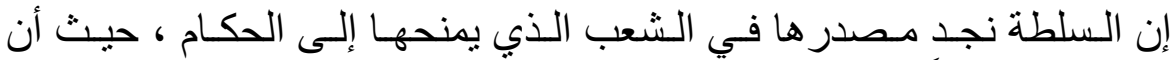

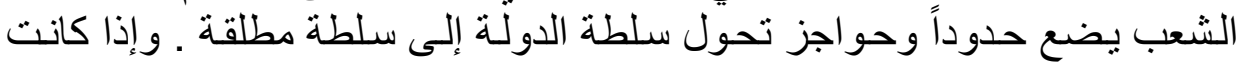

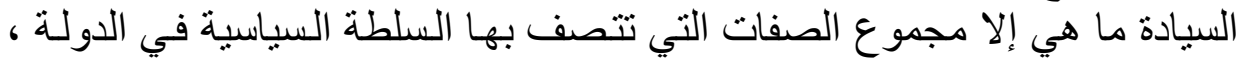

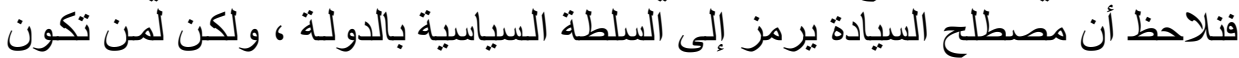

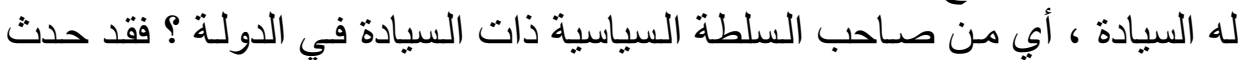

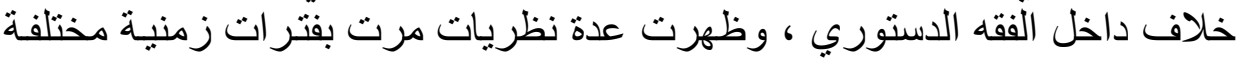

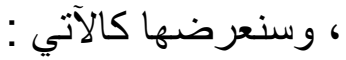

(1) د. صبحي عبده سعيد ، شرعية السلطة والنظام في حكم الإسلام ، مصدر سابق،صهب وما

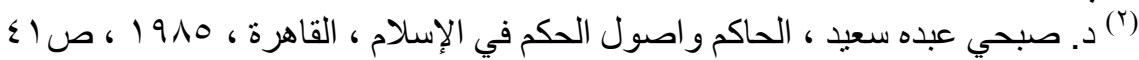

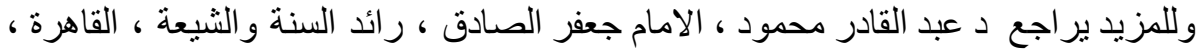

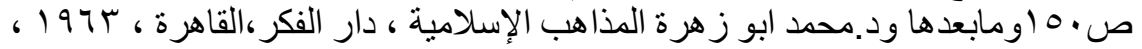

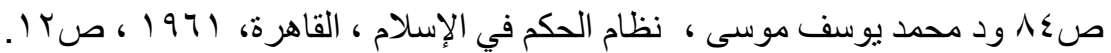




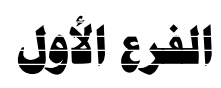

\section{نظّية سياندة ألأهة}

هذه النظريـة ذات الأصل الفرنسي أخذت بها الثها الثورة الفرنسية متأثرة بأفكار

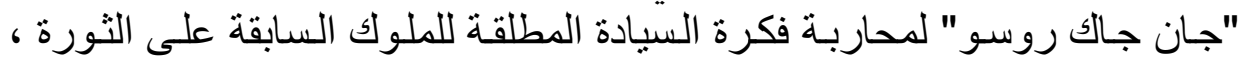

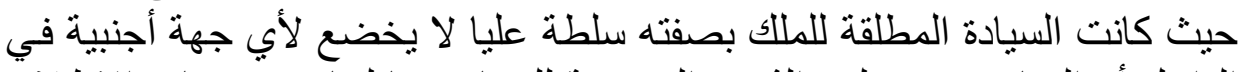

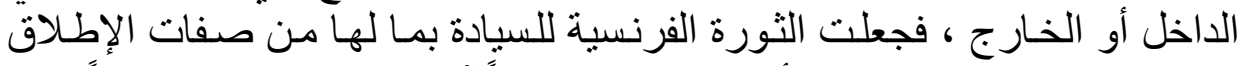

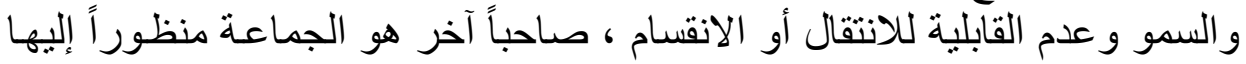

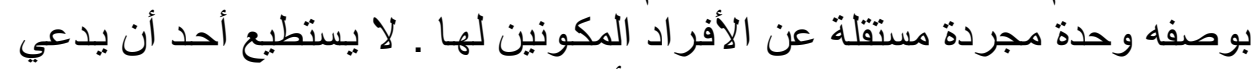

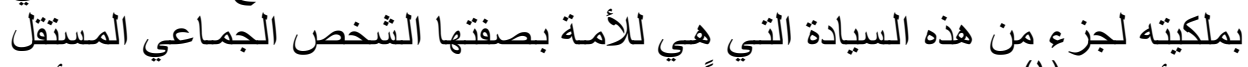

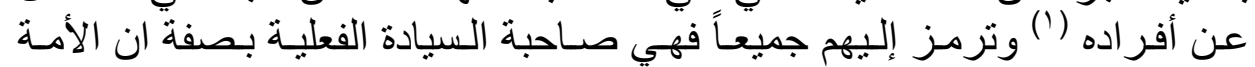

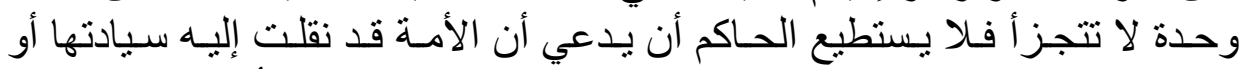

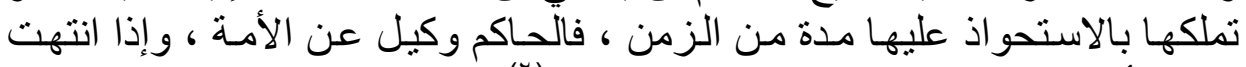

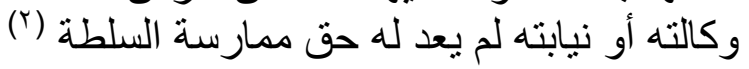

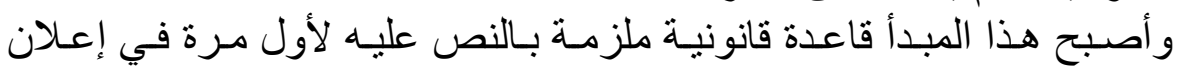

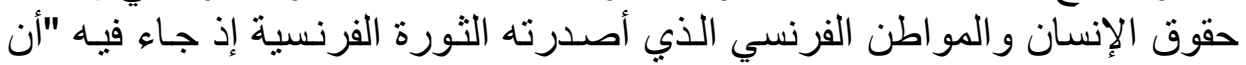

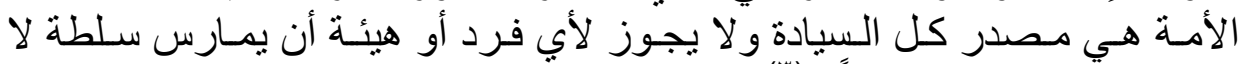

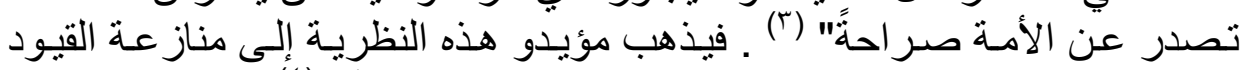

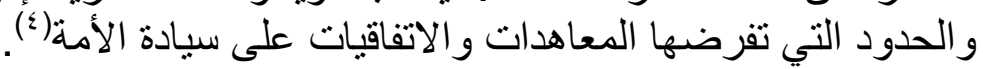
النتائج المترنبة على نظرية سيادة الأمة :

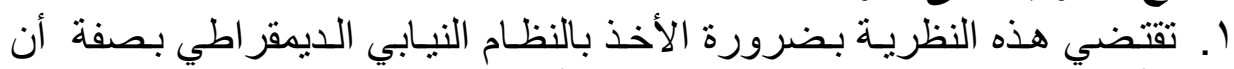

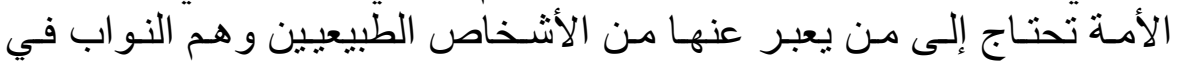

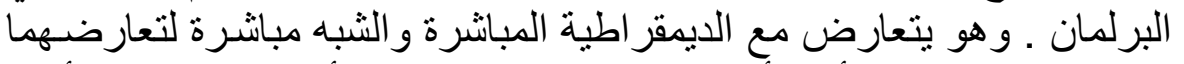

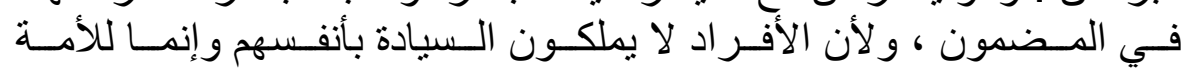

(1) دمسين عثمان محمد عثمان ، النظم السياسية و القانون الدستوري ، مصدر سابق ، صب؟

$$
\text { وما بعدها. }
$$

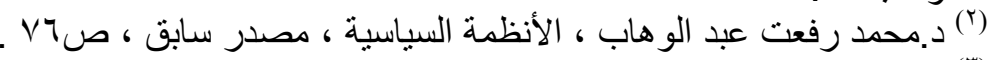

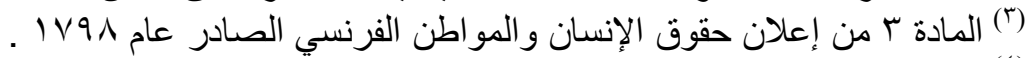

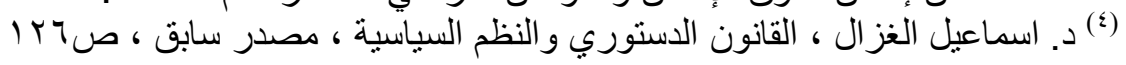


وبالديمقر اطية المباشـرة التي تتطلب تجز أت السيادة على الشعب وهو مـا لا يحصل هنا.

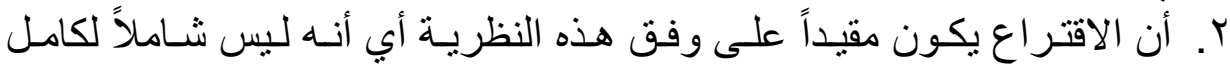

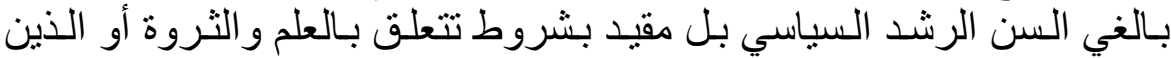

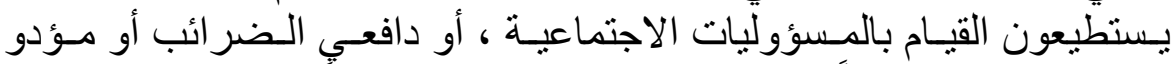

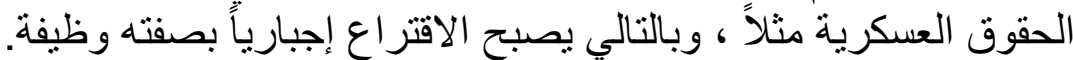

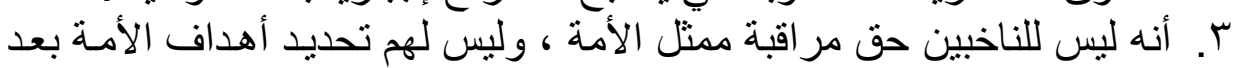
الانتخاب مباشرةً

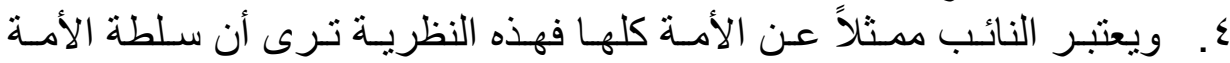
تتصف بالمشروعية لأنها تمثل إر ادة الشعب الناخب الناخب صـاحب الكفاءة العلمية

أهم الانتقادات التي وجهت إلى نظرية سيادة الأمة :

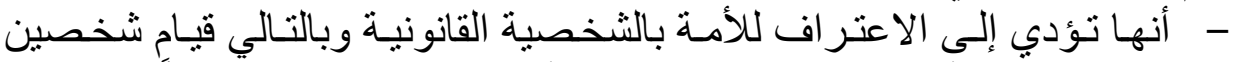

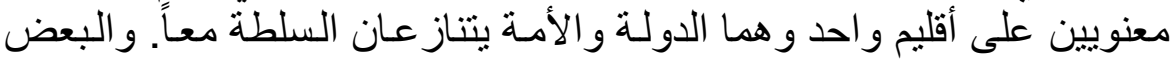

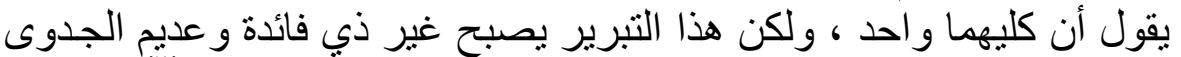

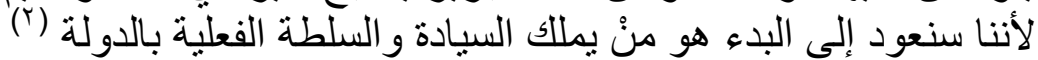

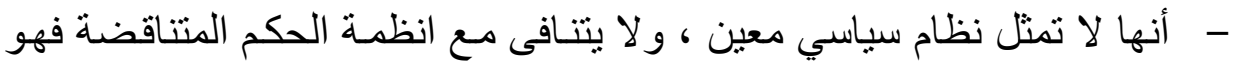

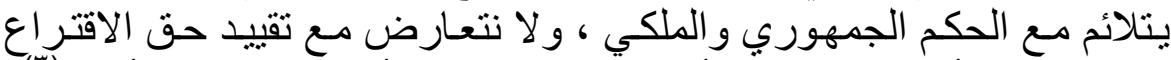
بشروط مالية أو علمية ويمكن أن نستخدم النظرية كأساس لنظم النهم حكم أقلية (r).

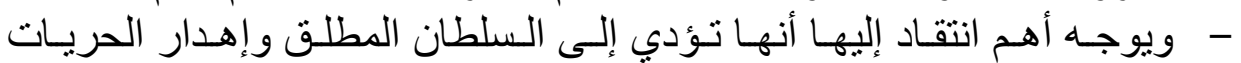

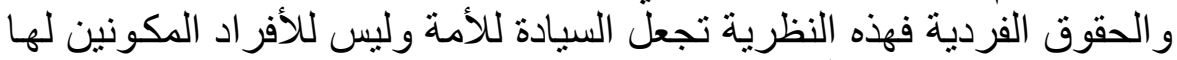

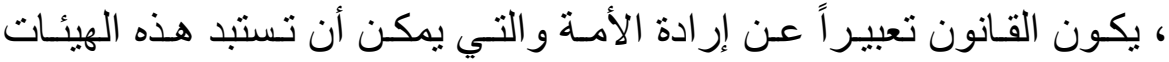

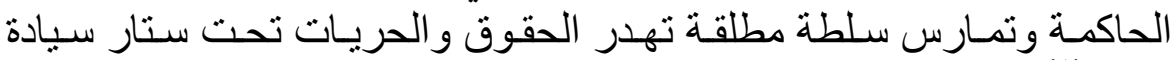

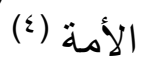

\section{| الثفوع الثاني}

(1) د.احسان حميد المفرجي وآخرون ، النظرية العامة في القانون الدستوري ، مصدر سابق ،

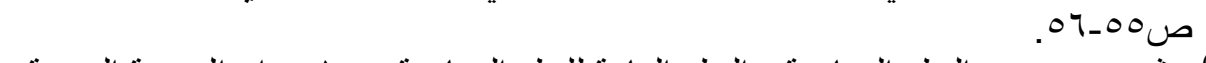
(ז) د.ثروت بدوي ، النظم السياسية ، النظم العامة للنظم السياسية ، ج) ، دار النهضة العربية ،

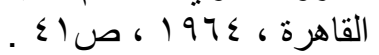

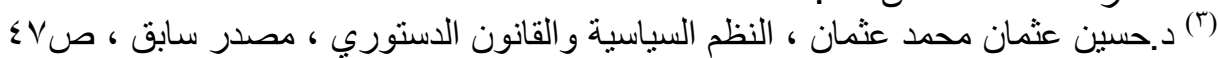

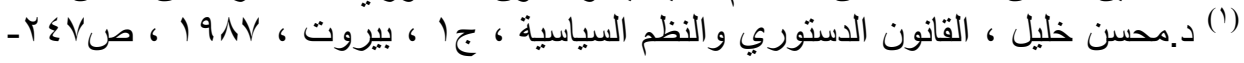




\section{نظوية سيادة الشعب}

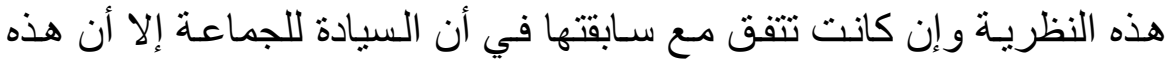

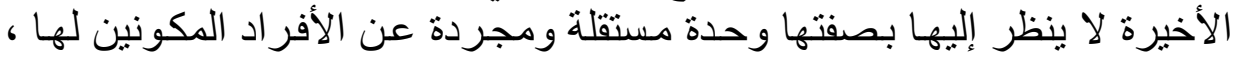

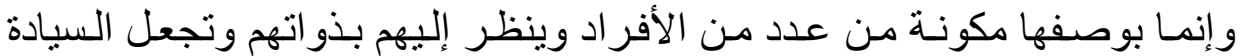

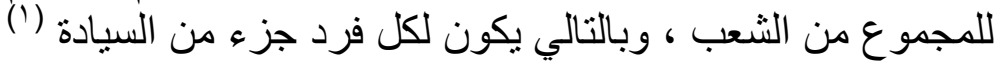

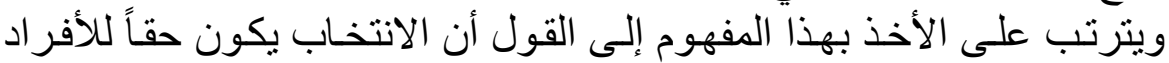

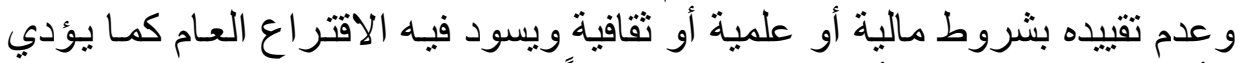

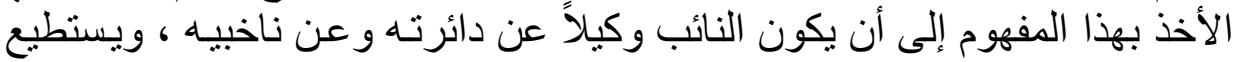

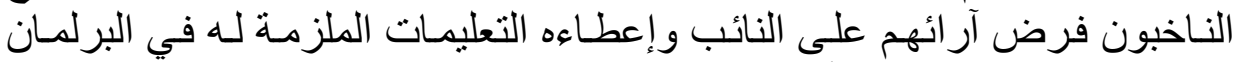

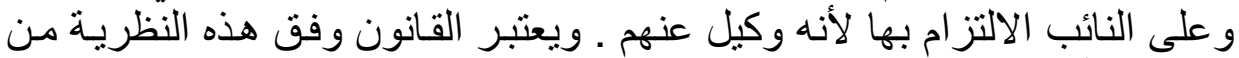

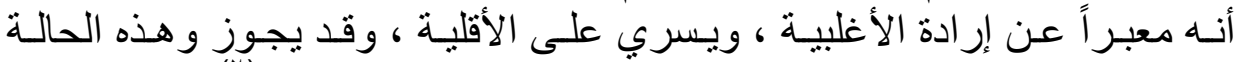

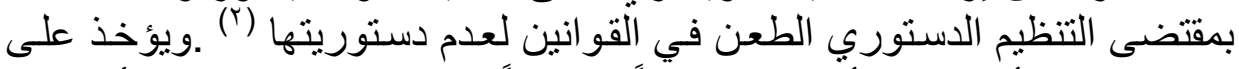

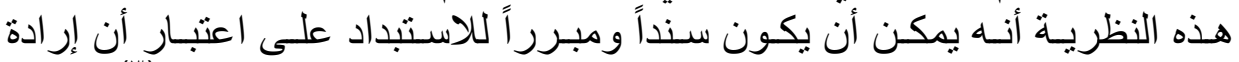

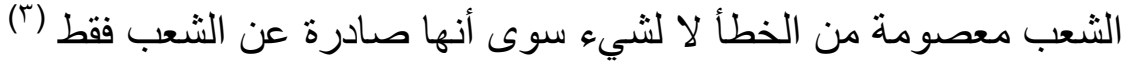

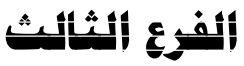

\section{|}

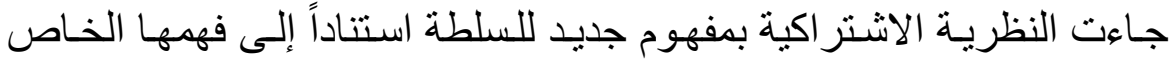

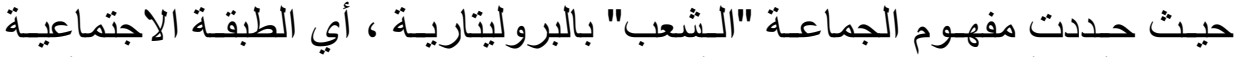

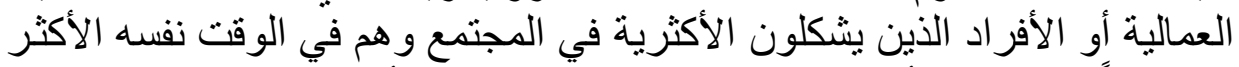

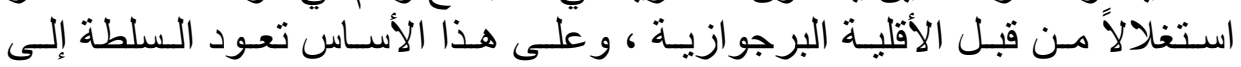

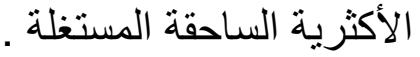
و عليه فالثرعية الديمقر اطية تعني على وفئه وفق هذا المفهوم ، أن السلطة تأتي

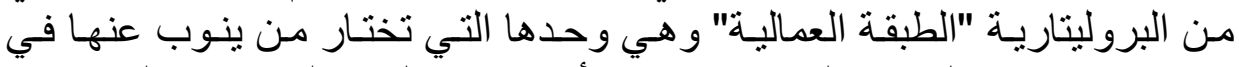
ممارستها ، و هذا المفهوم الجديد يستوحي بأفكاره من الفكر المهن الماركسي الذي وجد

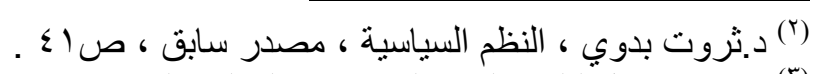

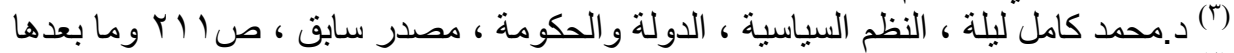

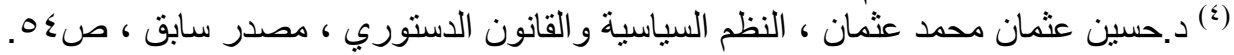


له تطبيقاً في أورباً الثرقية والاتحاد السوفييتي سابقاً ، فكل حكومة لا تمنل الطبقة

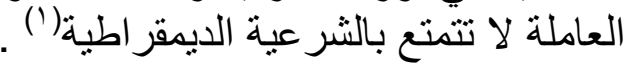

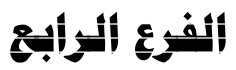

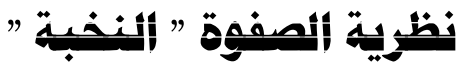

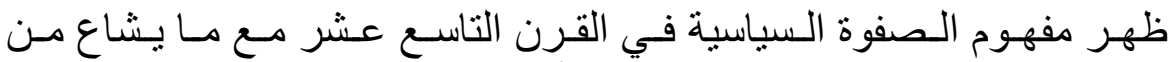

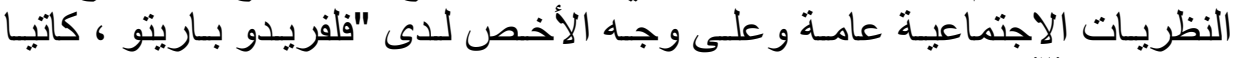

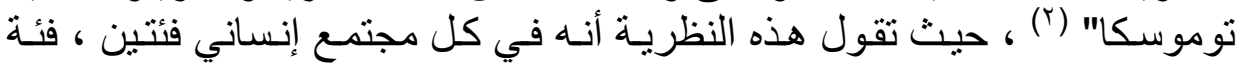

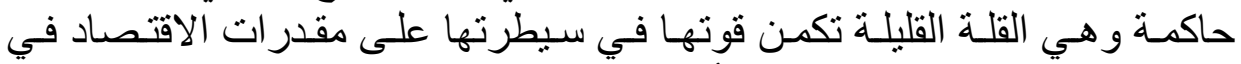

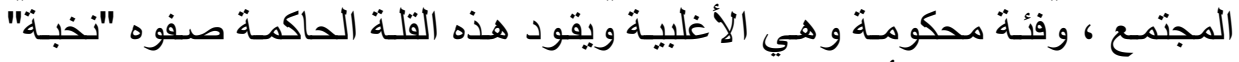

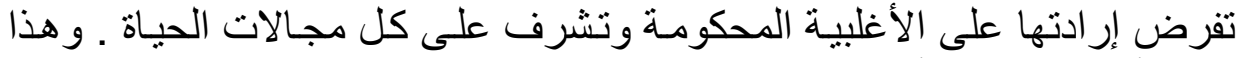

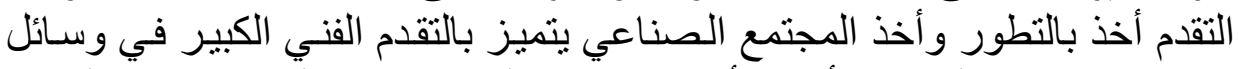

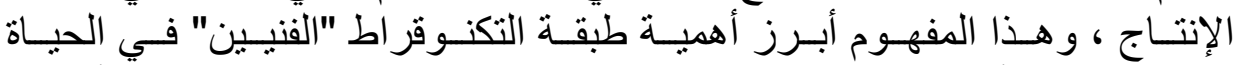

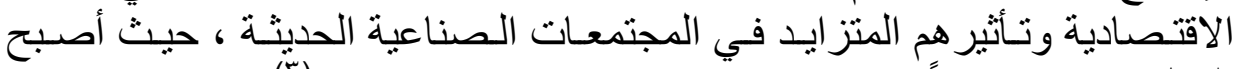

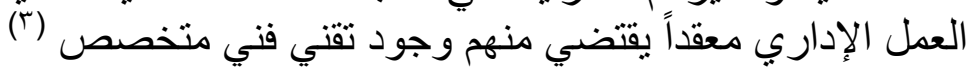

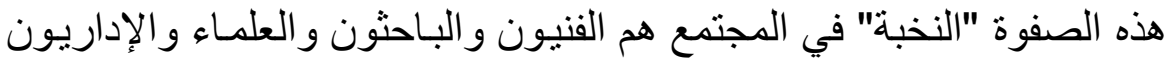

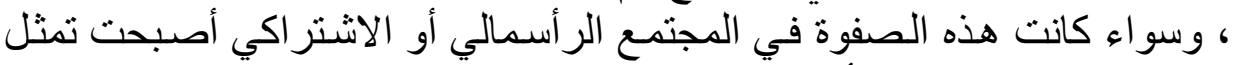

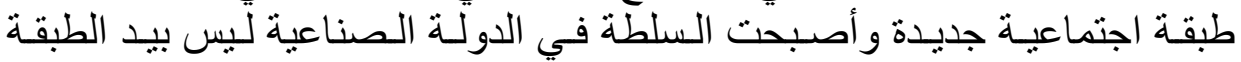

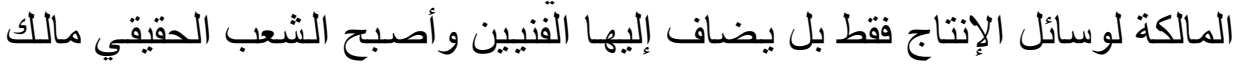

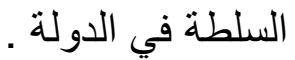

\section{ثitif ithif}

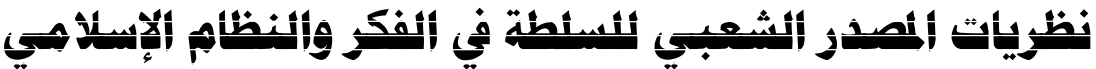

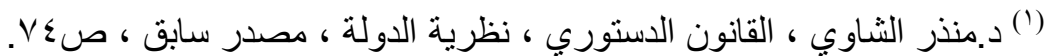

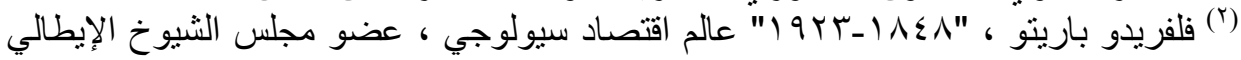

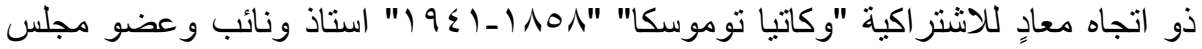

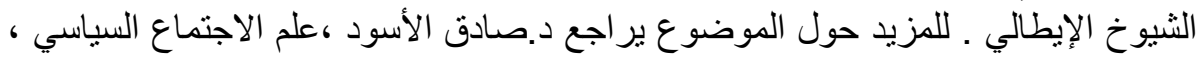

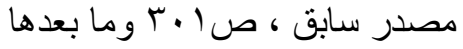
(1) د.إحسان حميد المفرجي و آخرون ، النظ النظرية العامة في القانون الدستوري و النظام الدستوري

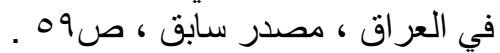




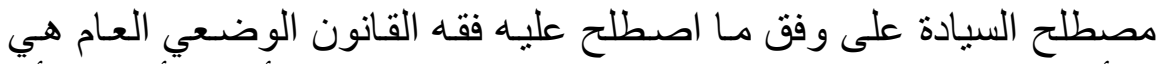

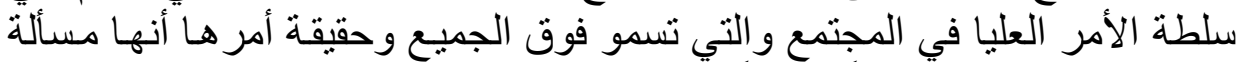

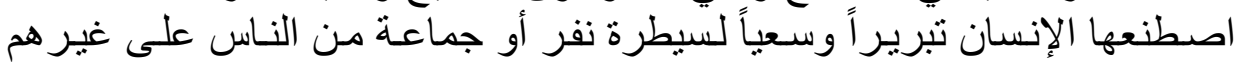

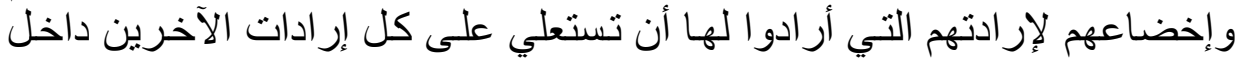

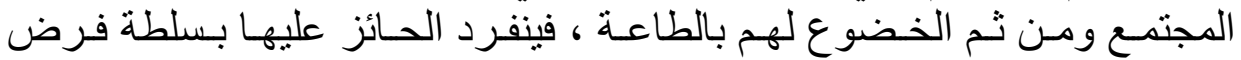

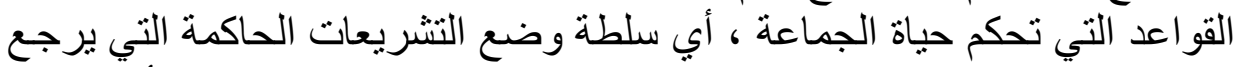

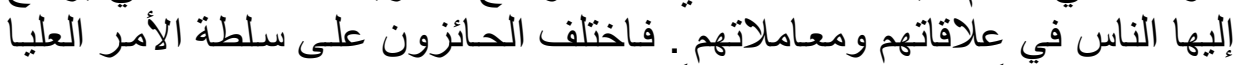

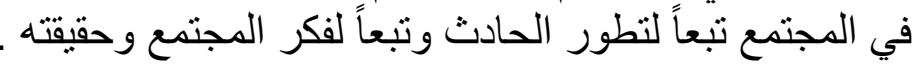

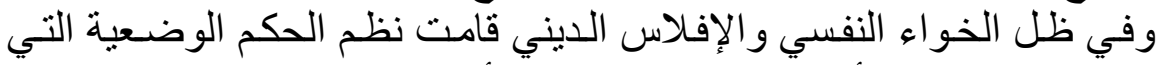

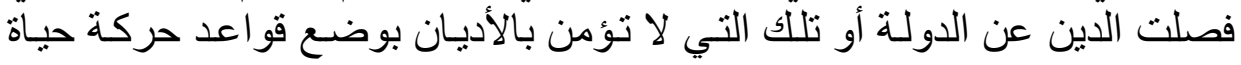

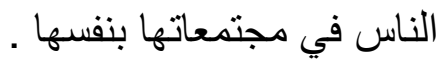

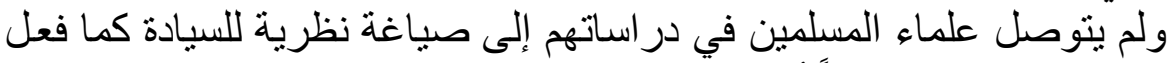

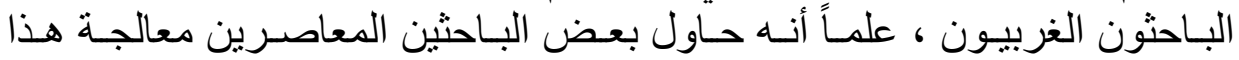

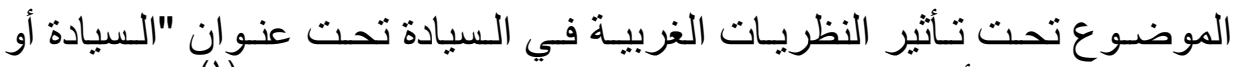

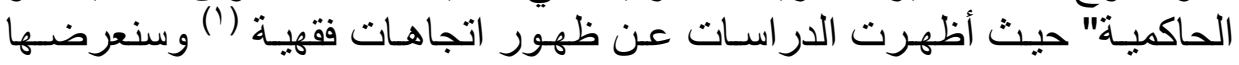

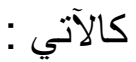

\section{|لأفرئ الأولى}

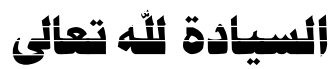

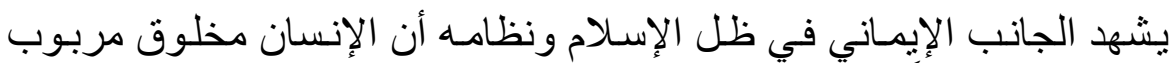

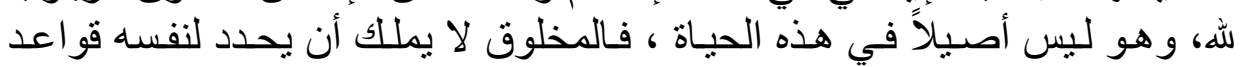

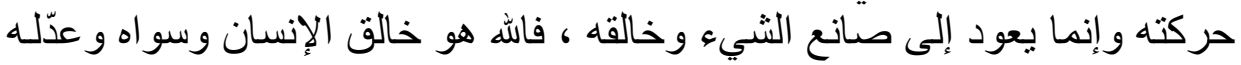

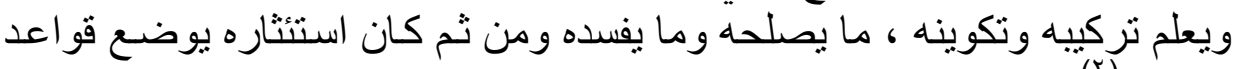
حركته (r) وتأسيساً على ذلك لا يوجد في مجتمع المسلمين و لا في نظام الحكم الإسـلامي

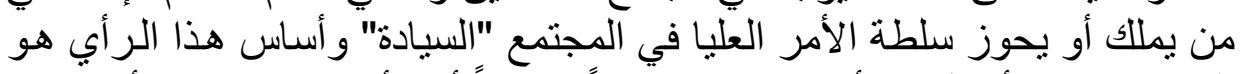

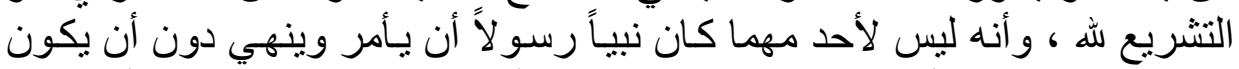

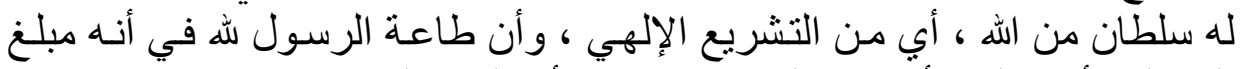

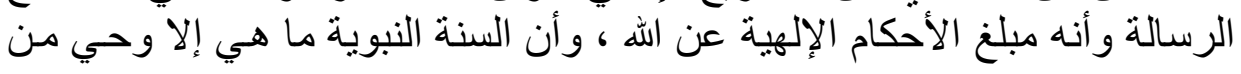

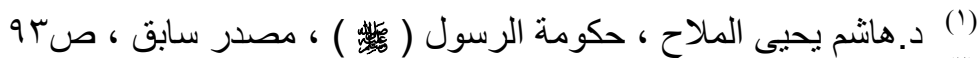

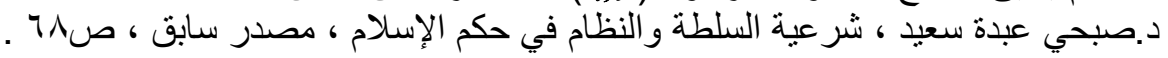




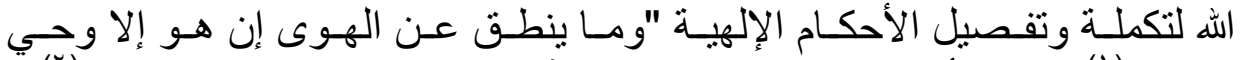

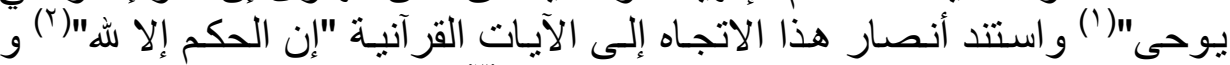

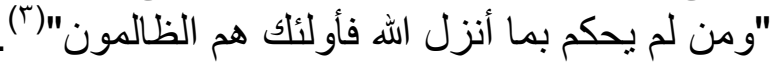

\section{|الفضرع الثناني}

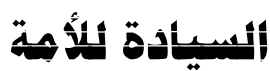

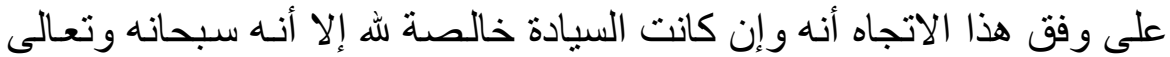

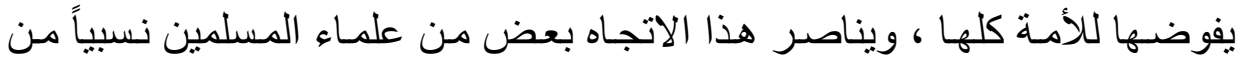

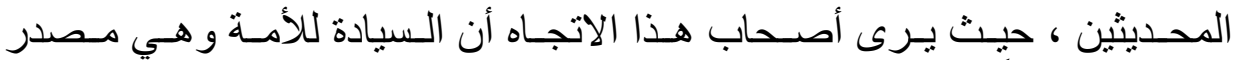

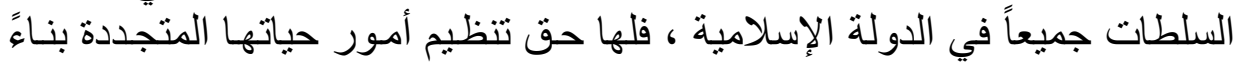

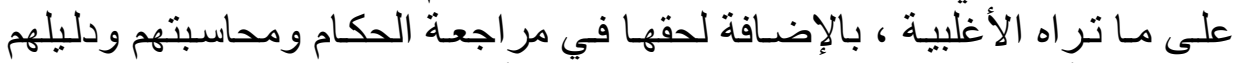

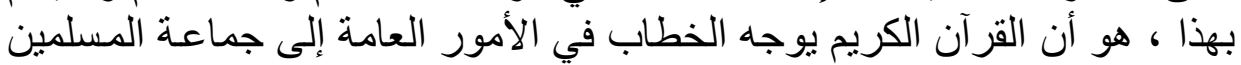

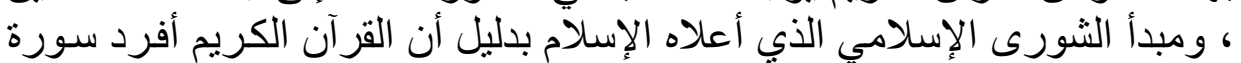

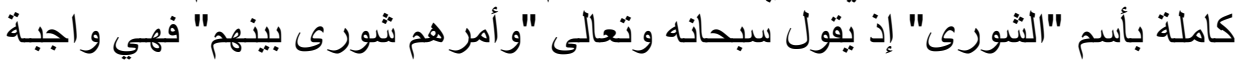

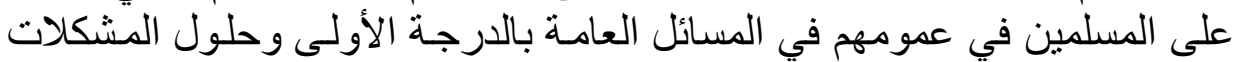

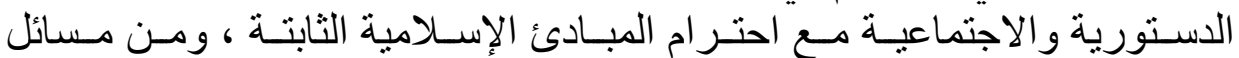

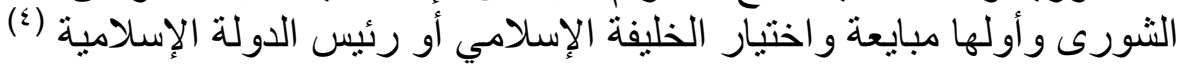

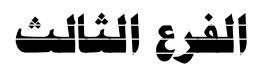

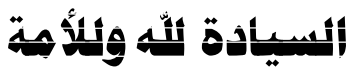

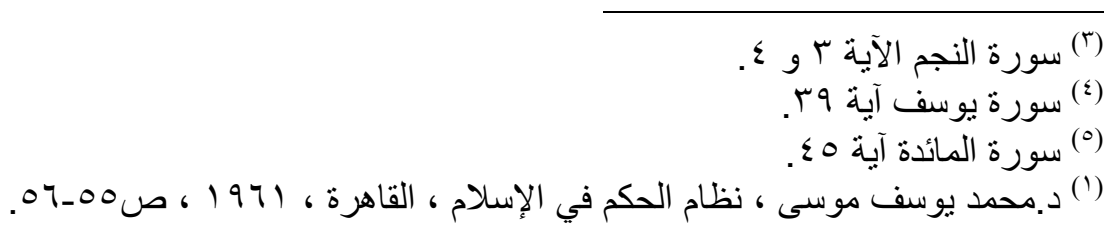




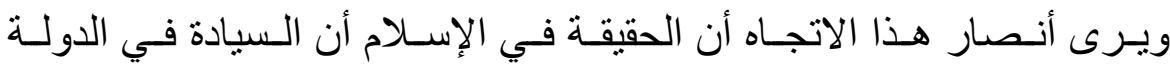

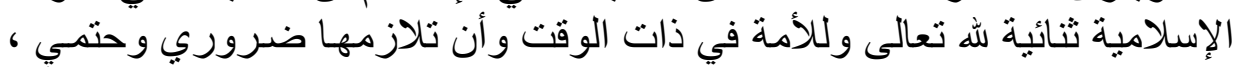

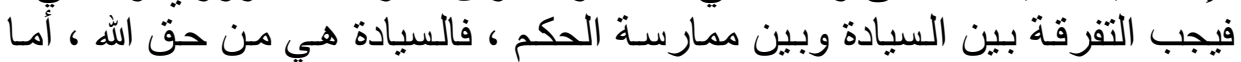

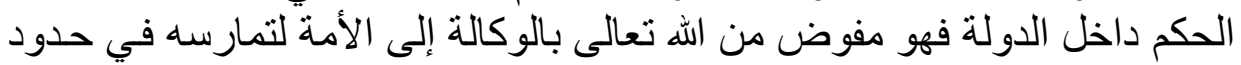

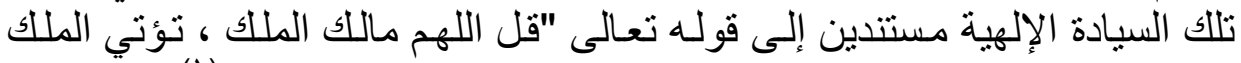

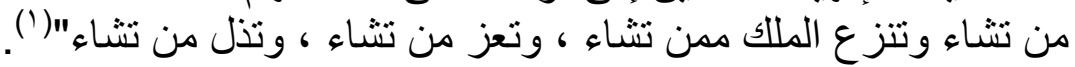

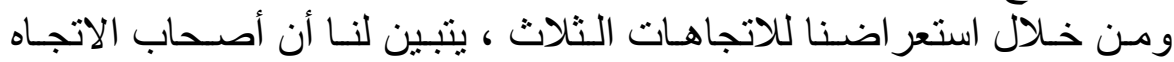

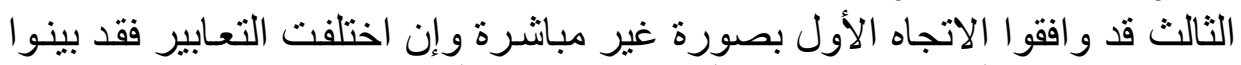

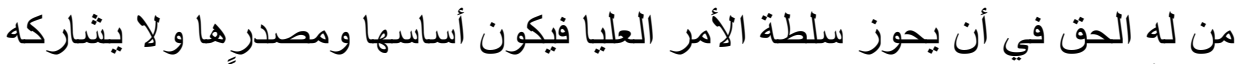

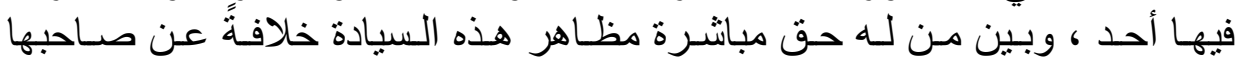

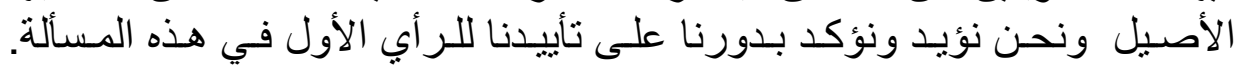

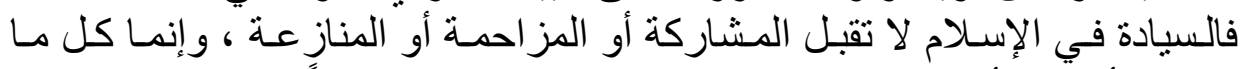

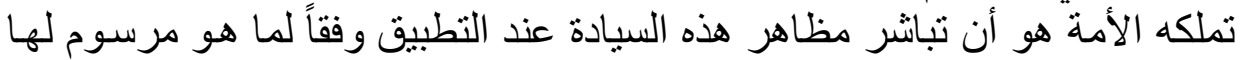

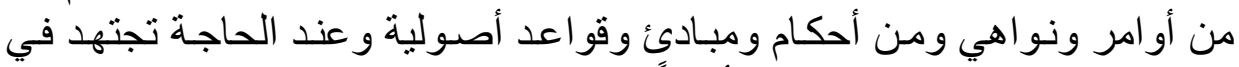

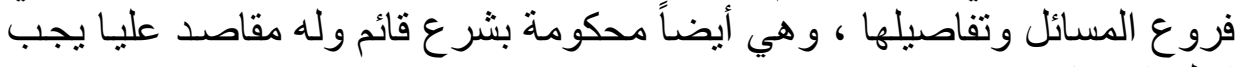

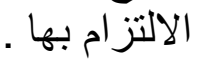

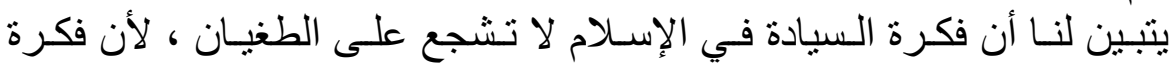

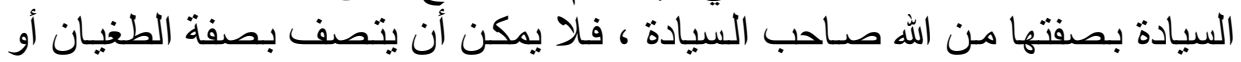

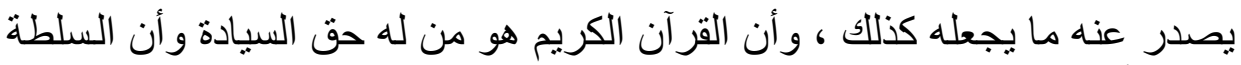

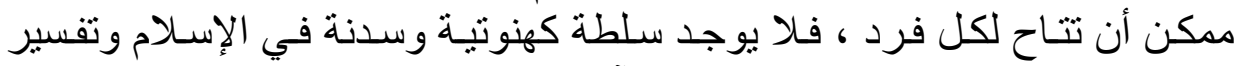

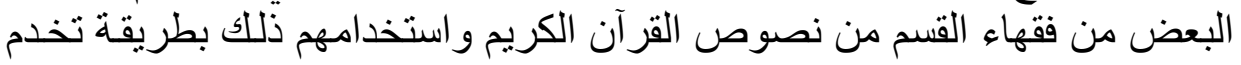

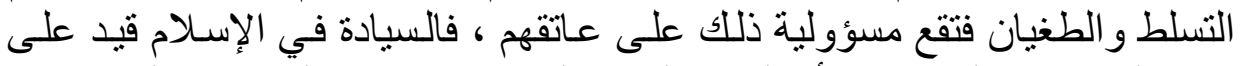

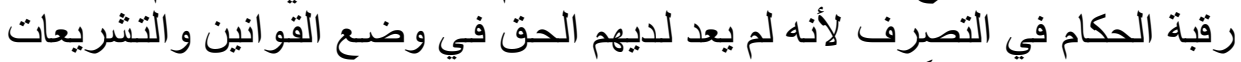

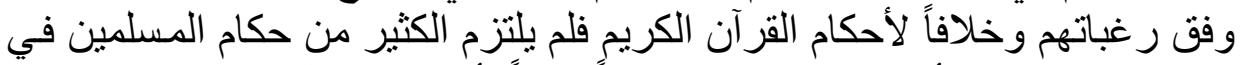

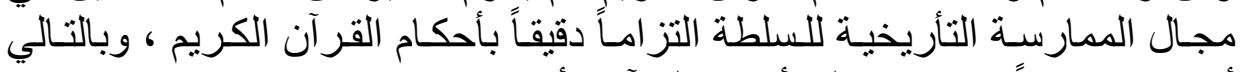

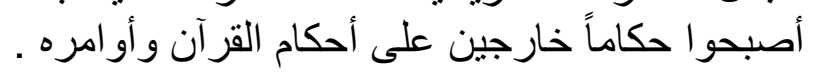

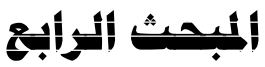

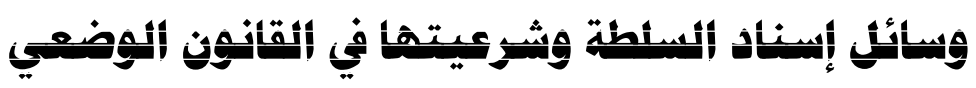

$$
\text { (T) د.محمود رفعت عبد الوهاب ، النظم السياسية ، مصدر سابق ، ص1 ـ }
$$




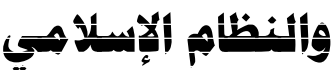

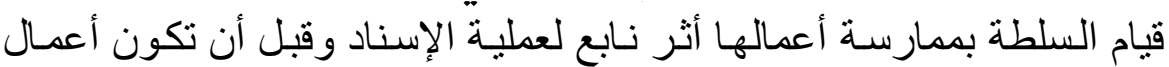

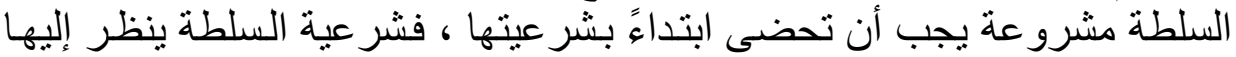

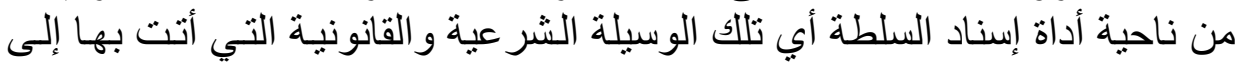

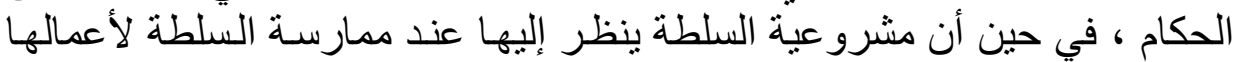

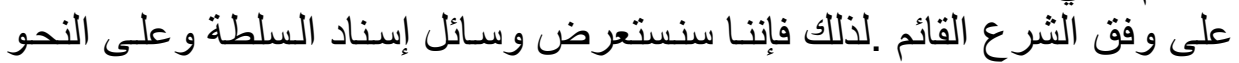
الآتي : - n

\section{Jiti}

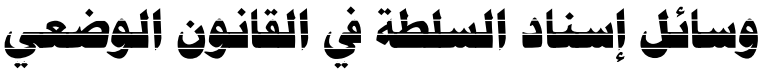

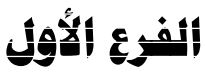

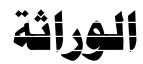

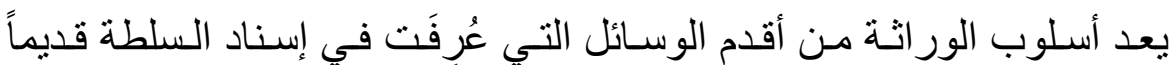

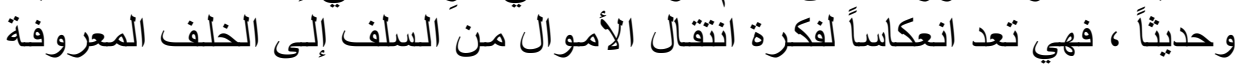

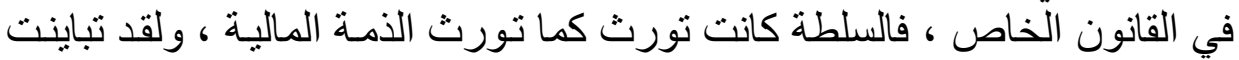

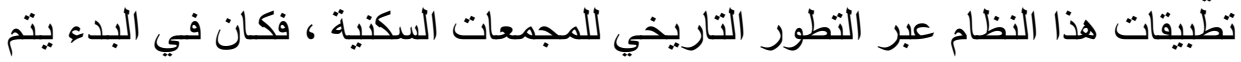

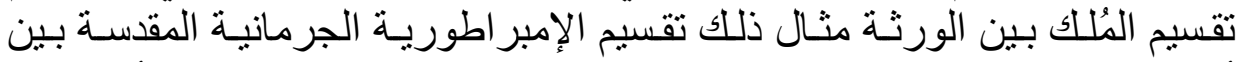

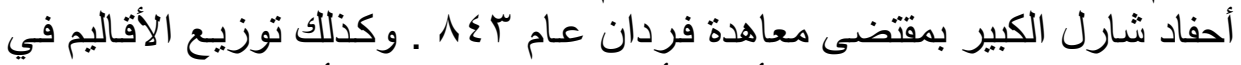

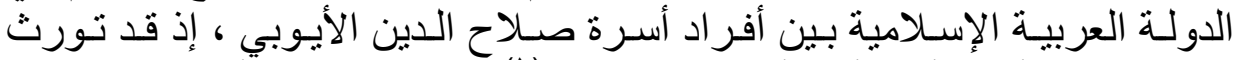

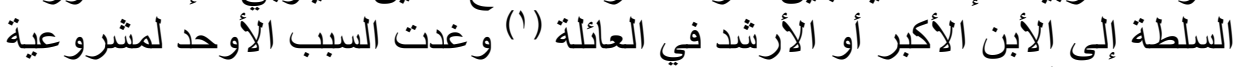

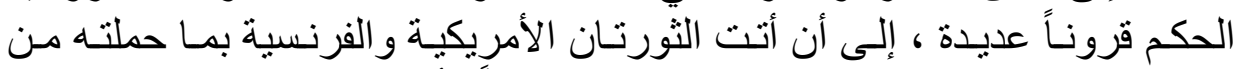

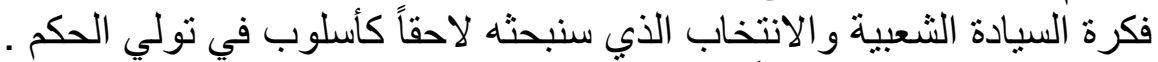

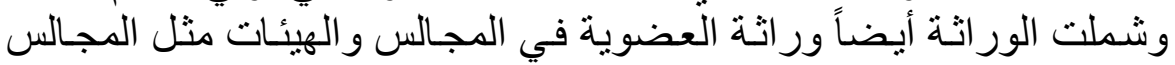

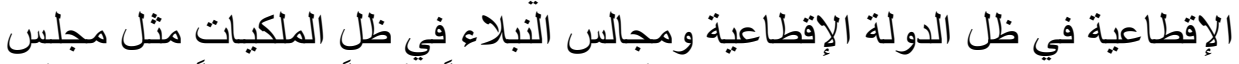

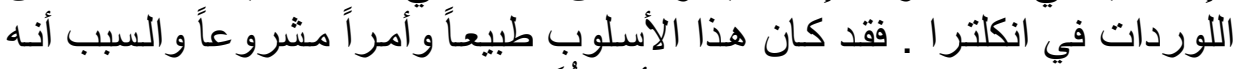

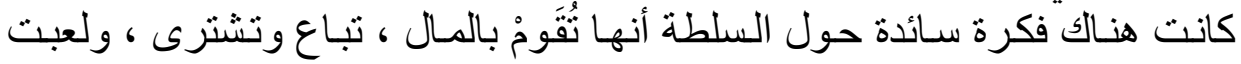

(1) د.كمال الغالي ، مبادئ القانون الدستوري والنظم السياسية ، طه ، منشور ات جامعة دمشق

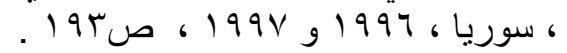




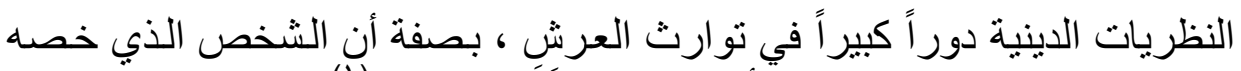

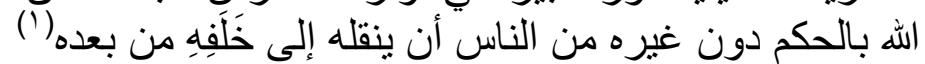

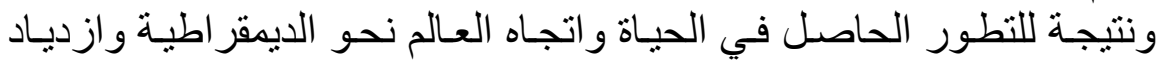

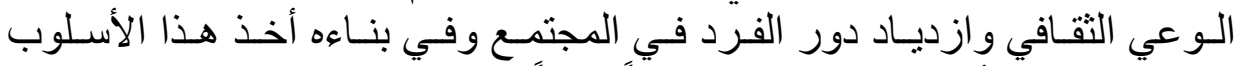

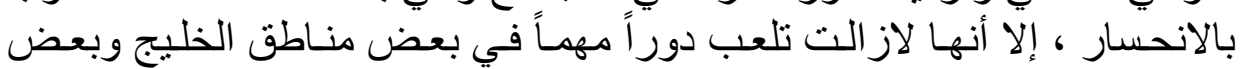

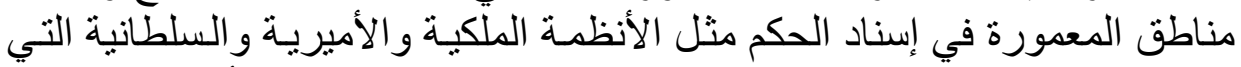

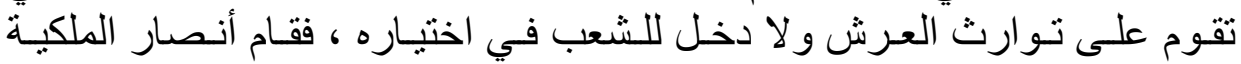

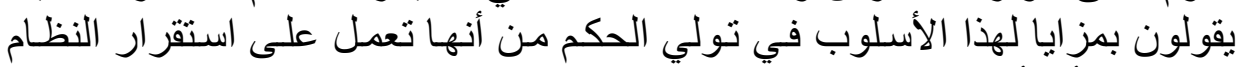

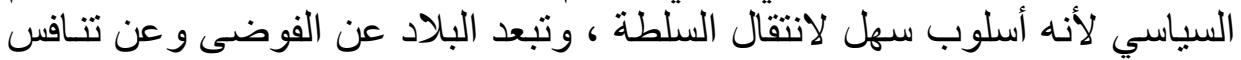

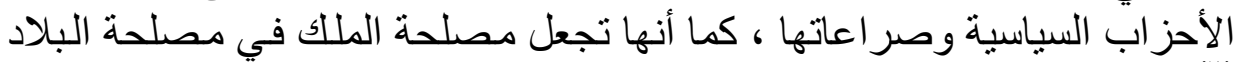

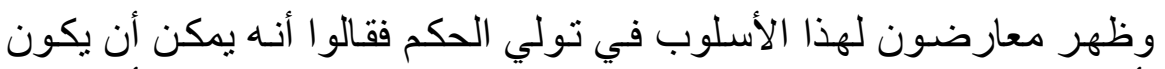

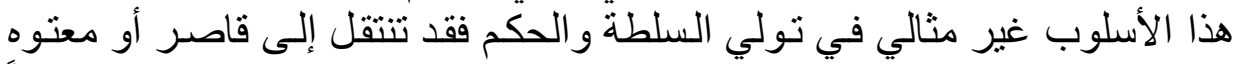

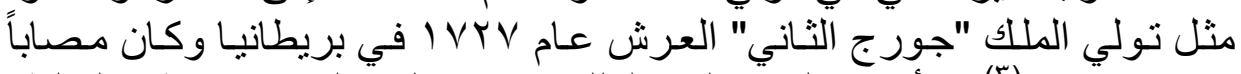

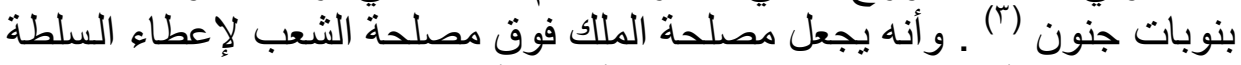

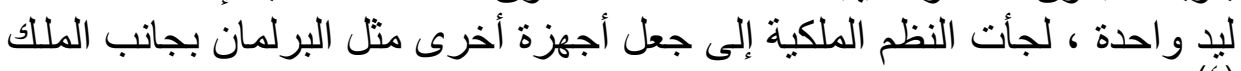

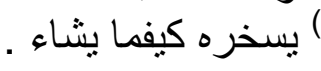

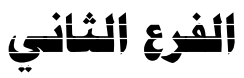

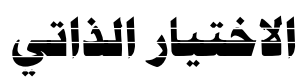

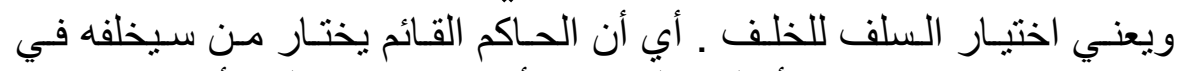

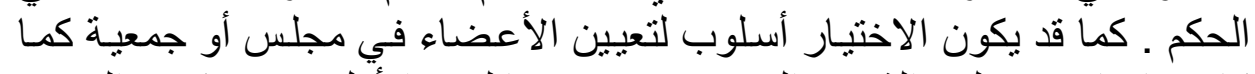

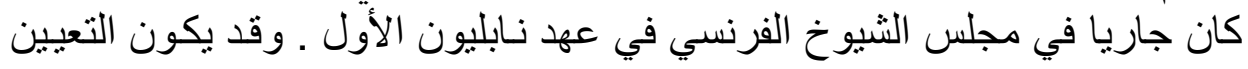

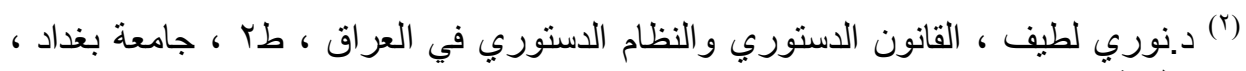

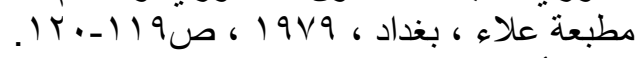

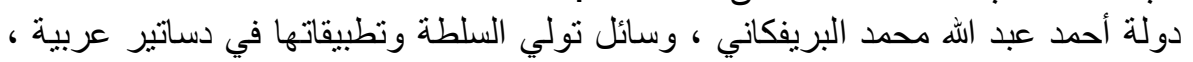

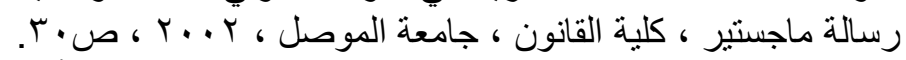

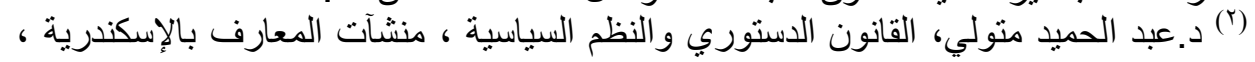

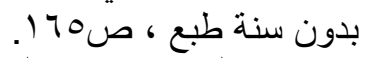

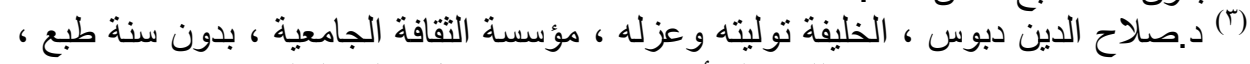

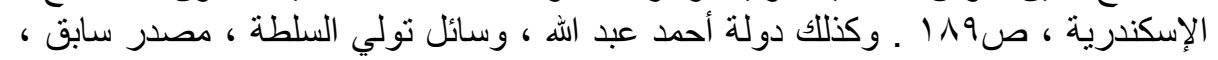

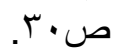


منوقفا على موافقة الشعب ـ كمـا في البيعـة في الدولـة الإسـلامية ــ والتي سنأتي

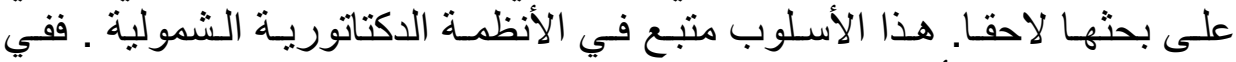

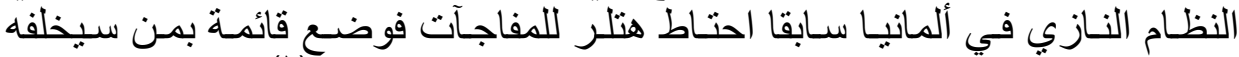

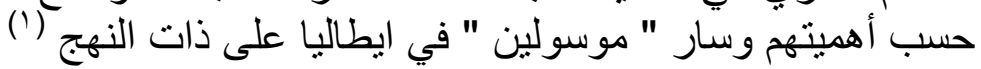

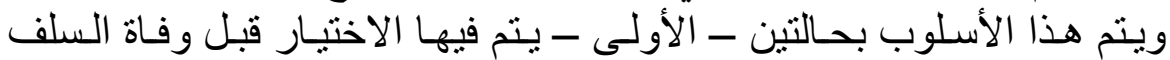

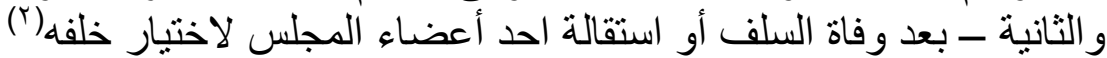

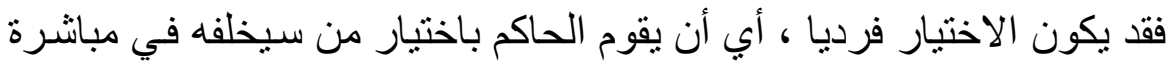

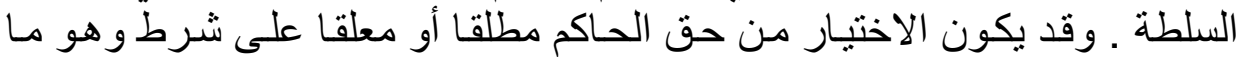

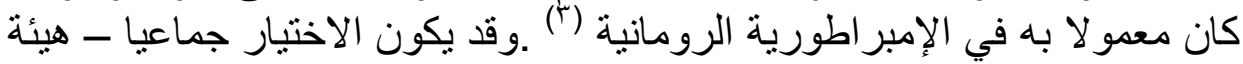

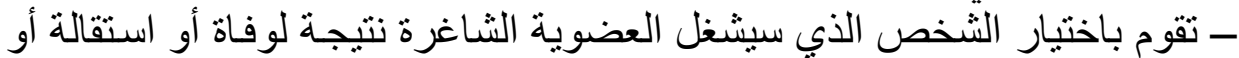

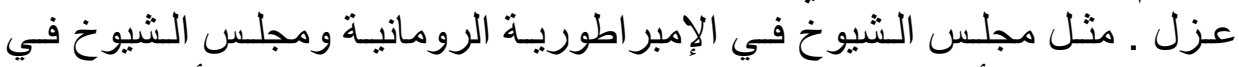

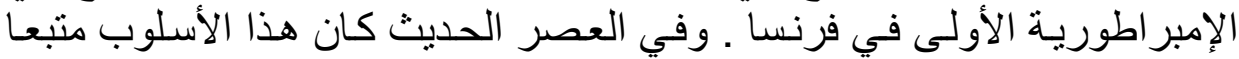

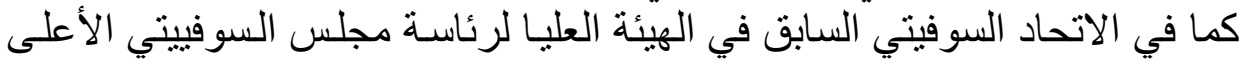

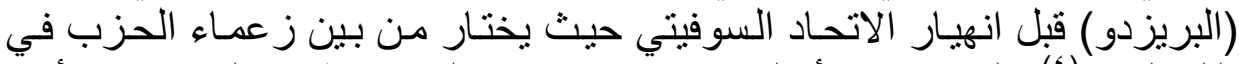

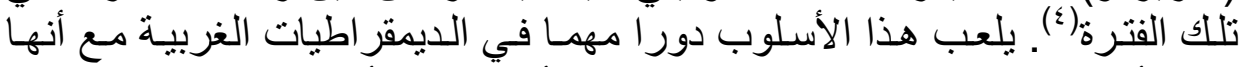

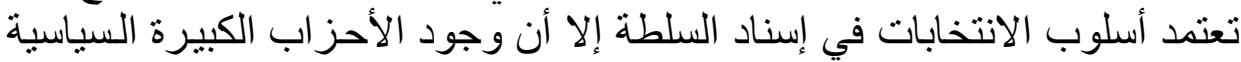

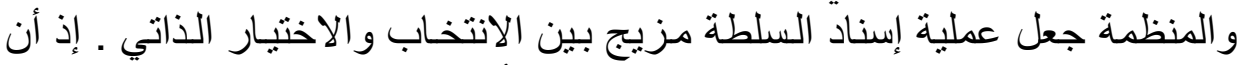

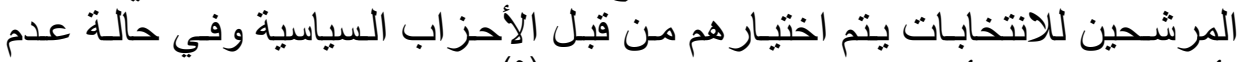

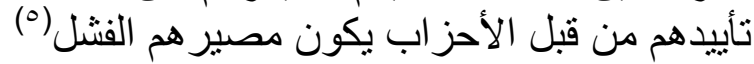

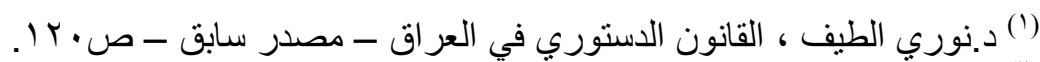

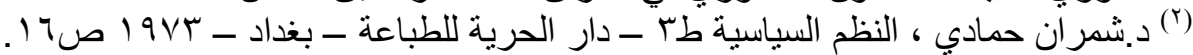

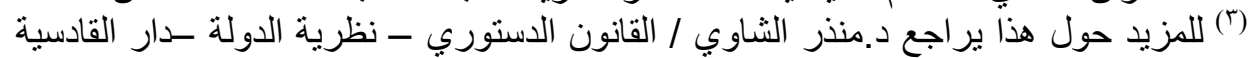

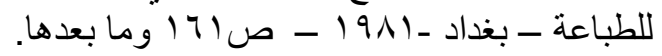

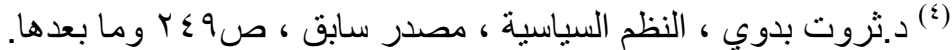

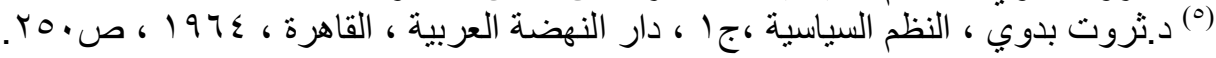




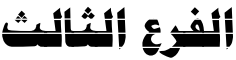

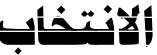

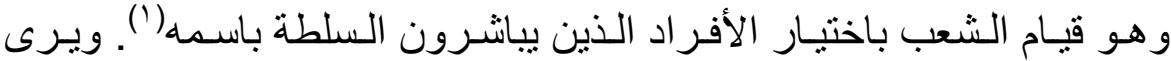

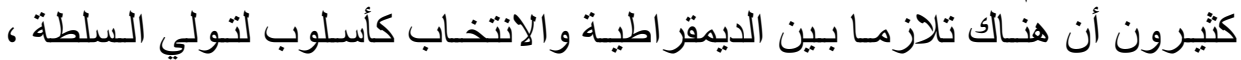

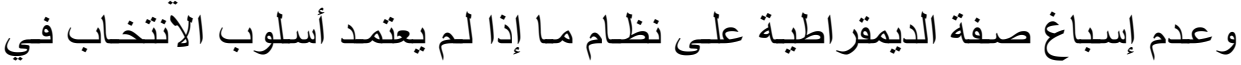

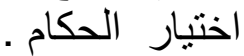

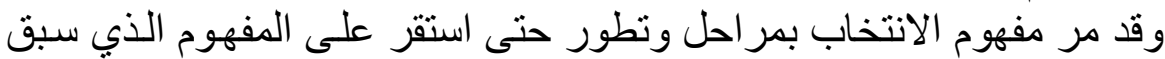

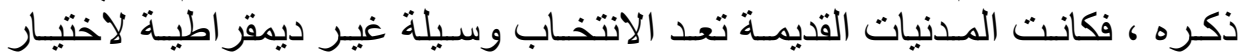

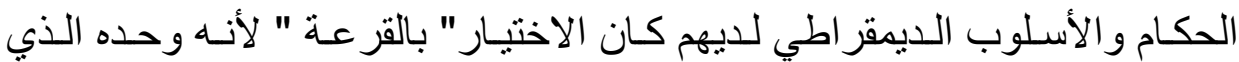

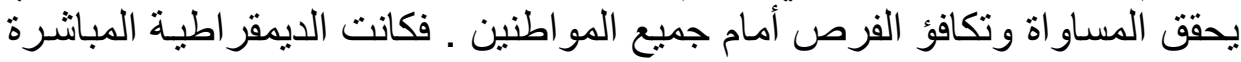

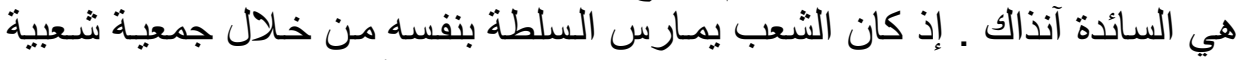

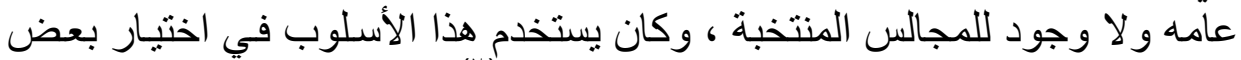

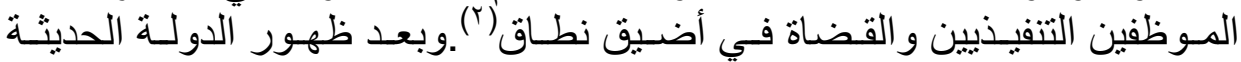

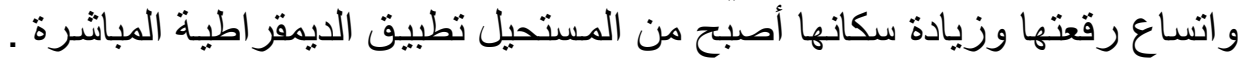

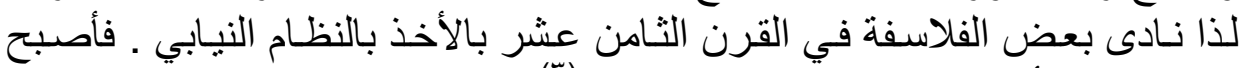

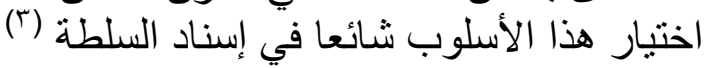

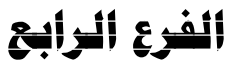

(') د. حميد الساعدي ، مبادى القانون الدستوري ، النظام الدستوري في العراق مصدر سابق ،

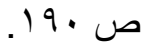

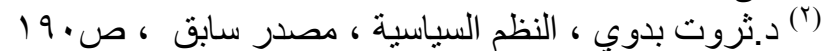

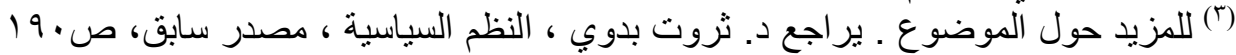

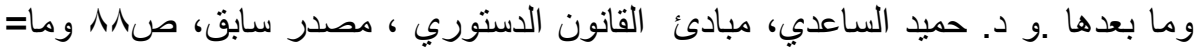

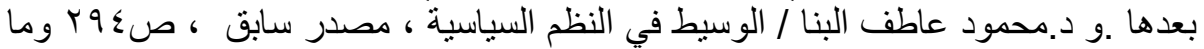

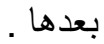




\section{stivini}

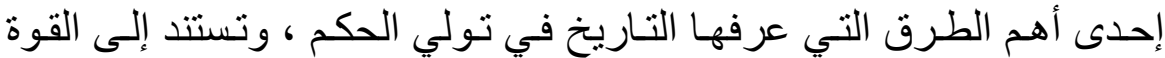

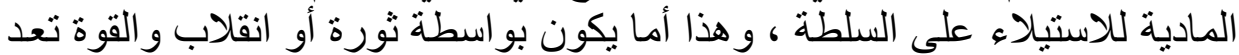

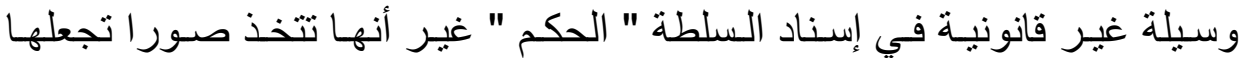

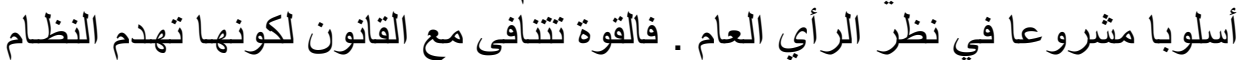

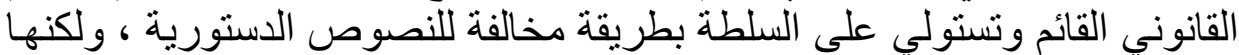

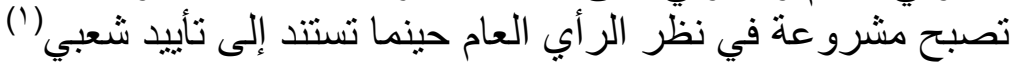

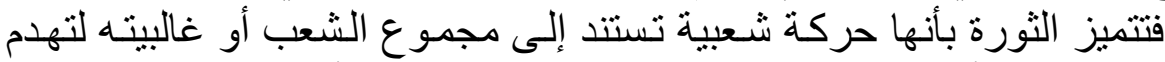

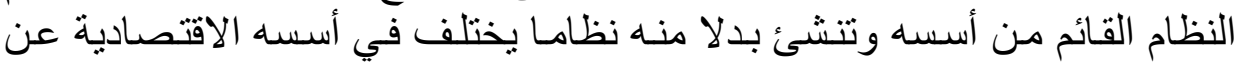

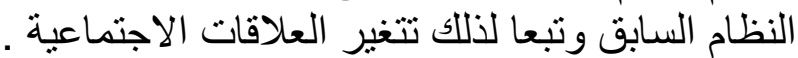

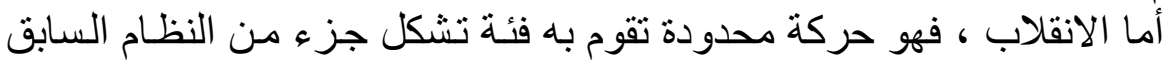

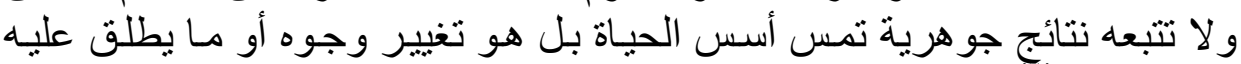

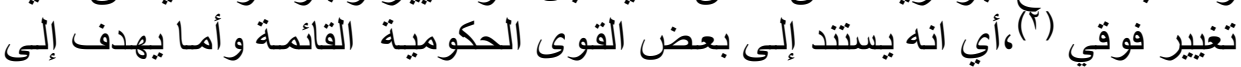

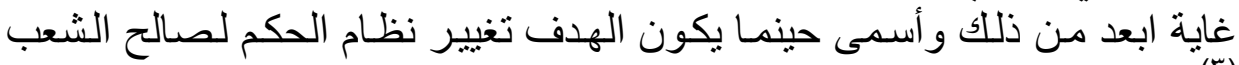

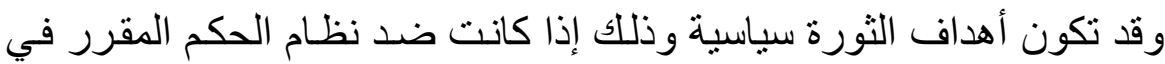

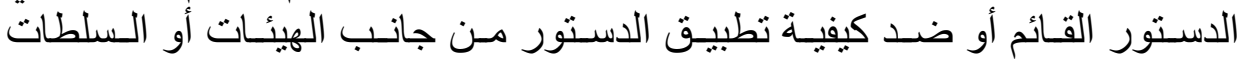

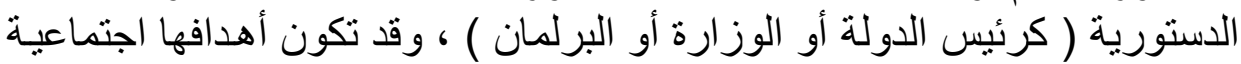

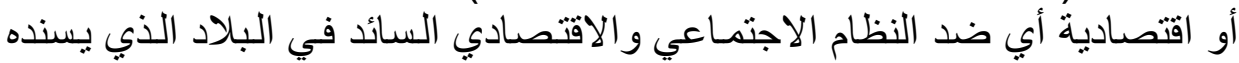

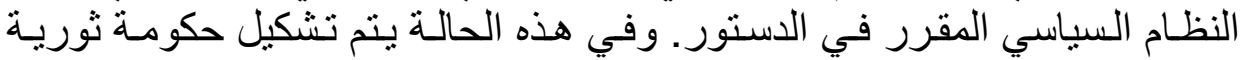

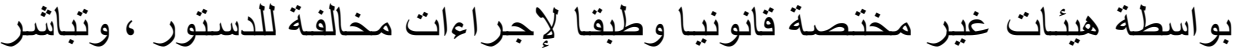

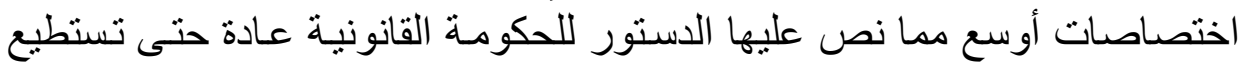

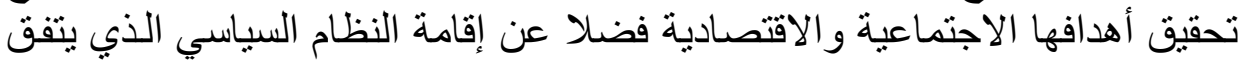

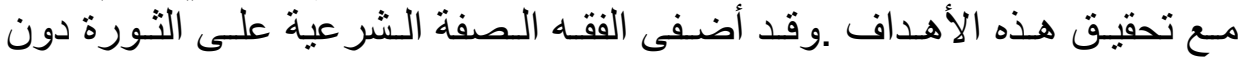

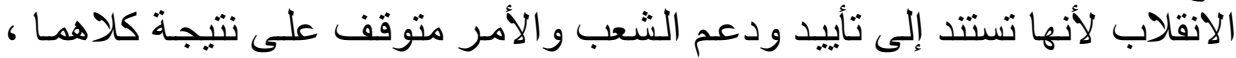

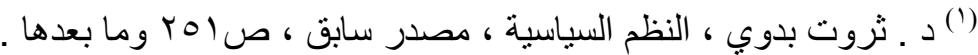

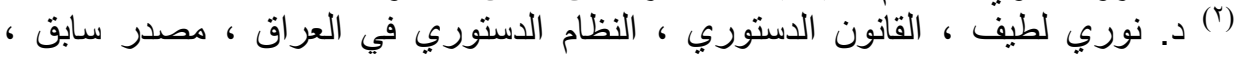


فنجاحهـــا يعنـي إضـفاء الـشر عية الجديـدة دون القديمـة أي الـشرعية الدسـتورية (السابقة) (1)

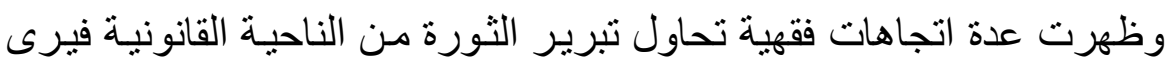

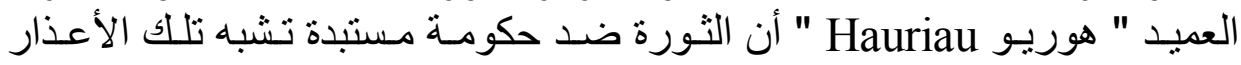

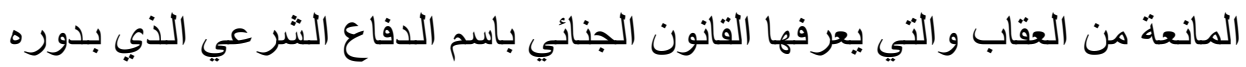

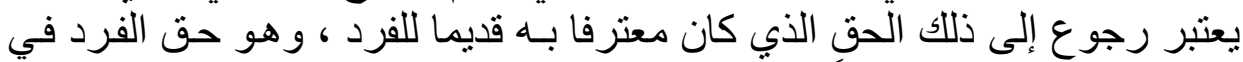

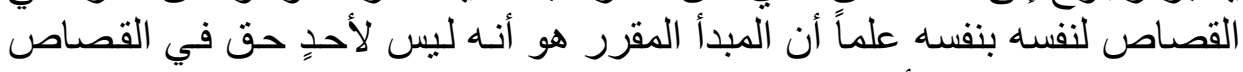

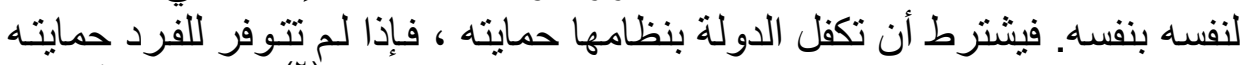

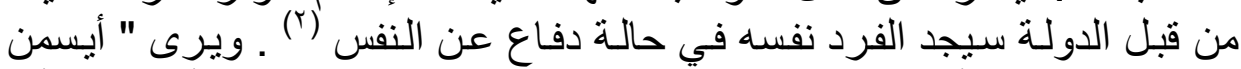
Esmein

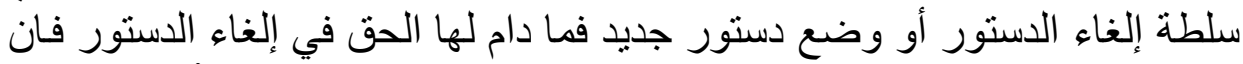

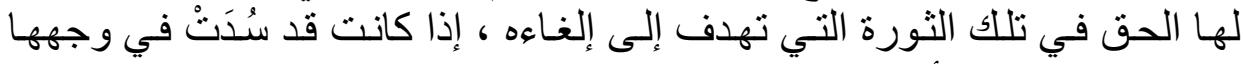

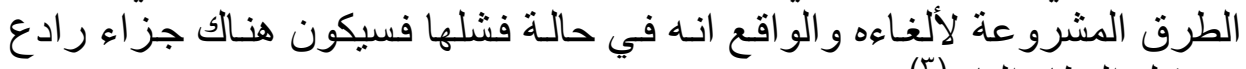

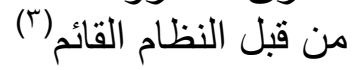
فالاستيلاء على السلطة بـالقوة لا يمكن أن يعد أسلوبا أو وسيلة قانونية لأنها

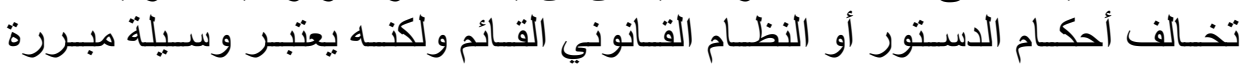

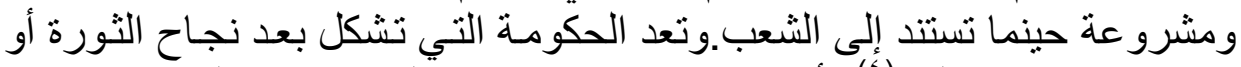

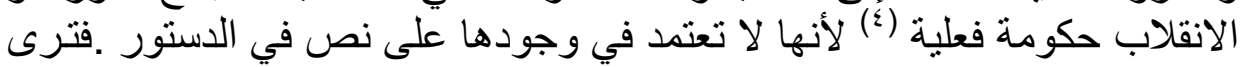

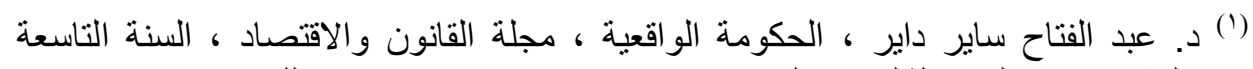

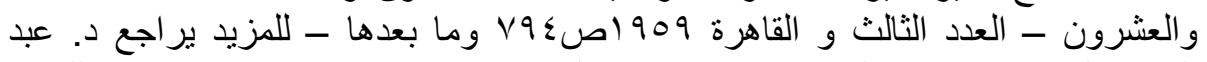

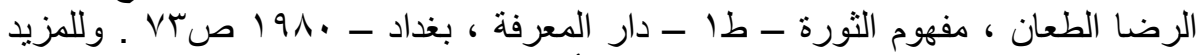

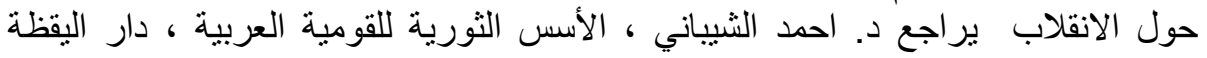

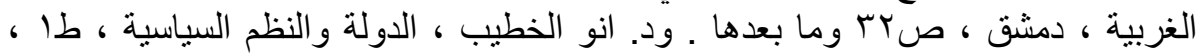

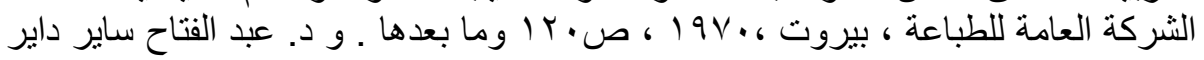

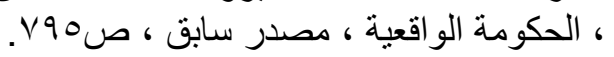

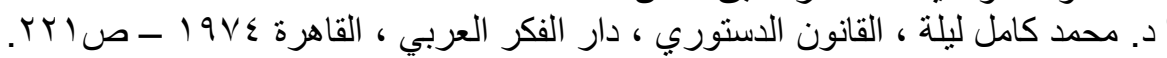

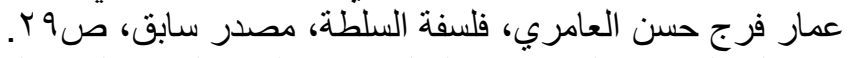

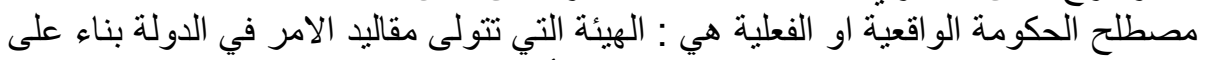
(๕)

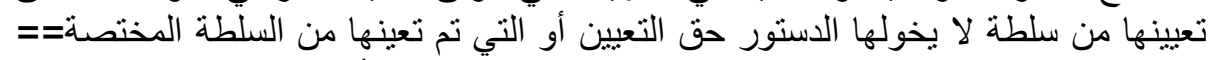

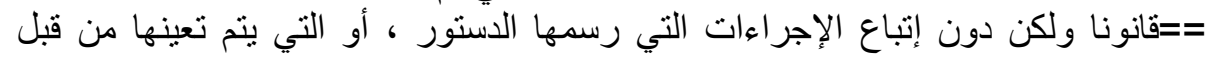

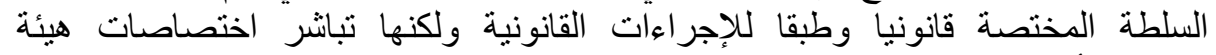

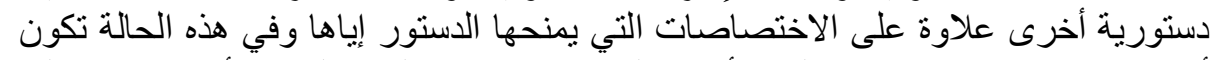

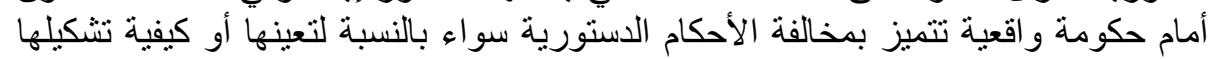


اغلب الذين يأتون إلى الحكم عن طريق الثورة أو الانقلاب بحـاولون تغطيـة هذه

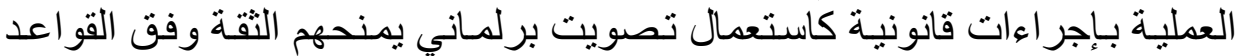

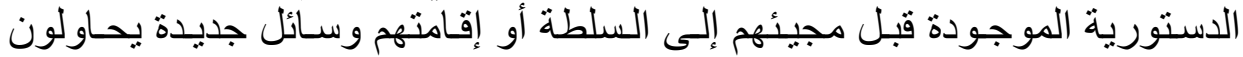
و هذا الأمر إذا كان يأتي من داخل البلد ، أي أن عملية التغير من داخل البلد

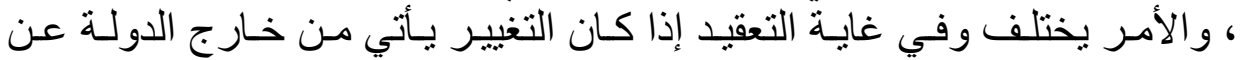

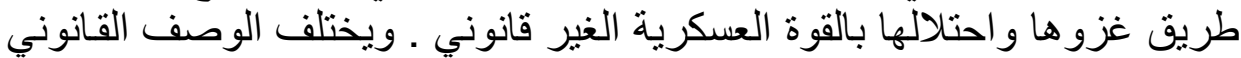

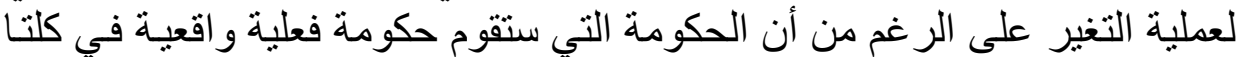

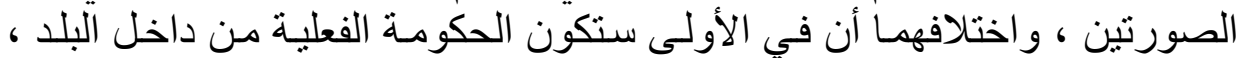

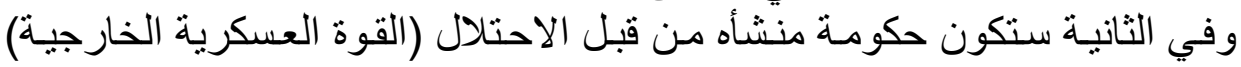

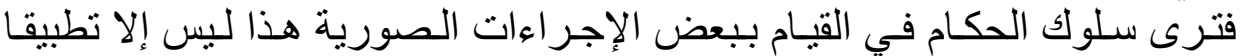

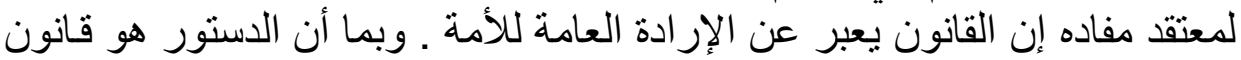

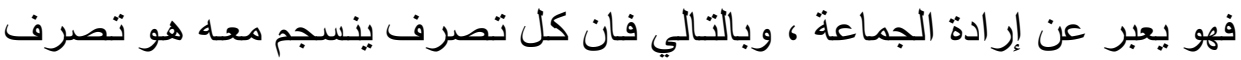

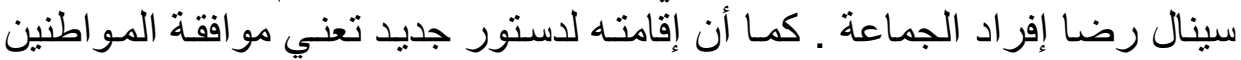

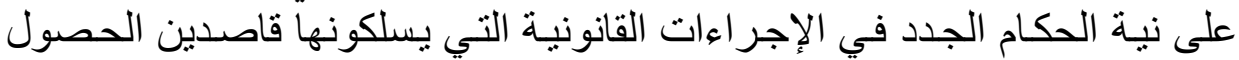

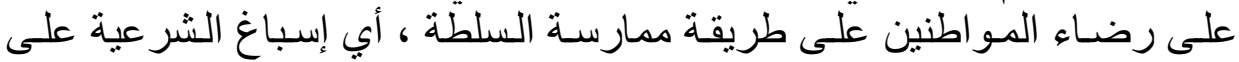

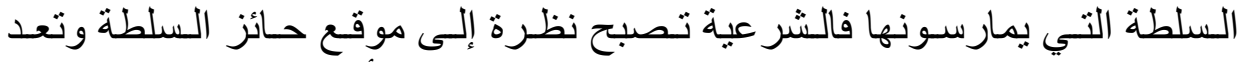

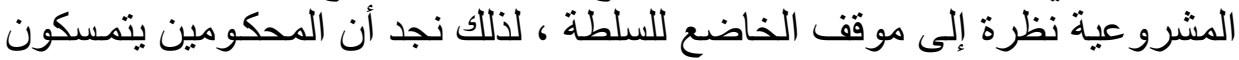

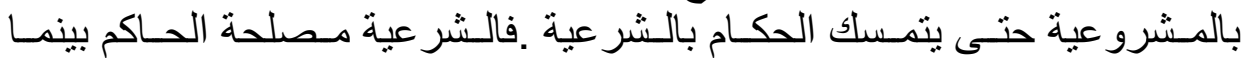

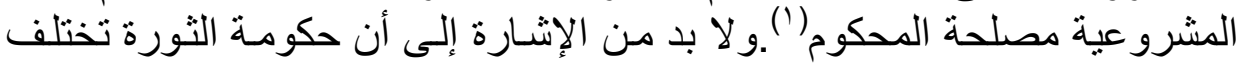

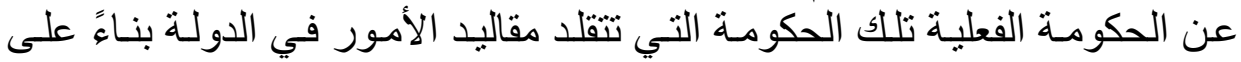

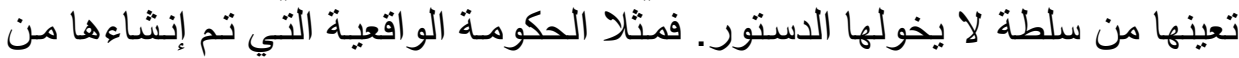

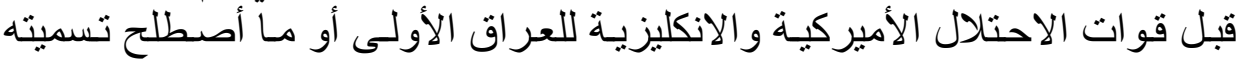

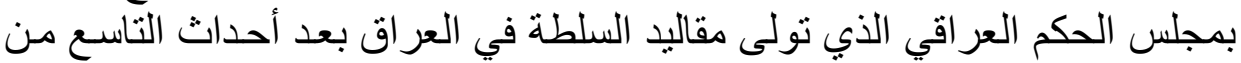

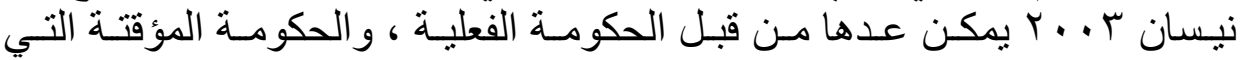

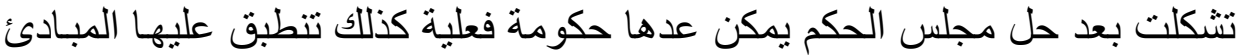
الخاصة بالحكو مة الو اقعية

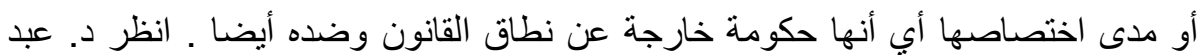

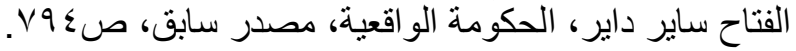
(1) د. سمير خيري ، المشرو عية في النظام الاشتر اكي ، دار القادسية للطباعة ، بدون سنة طبع 
فقد تكون الحكومة مشرو عة عند مجيئها للحكم لكن تبقى غير شـرعية بـالر غم من ذلك و هو ما حصل كذللك في فرنسا إبان حكومة المارشال " بيتان " وقد تكون

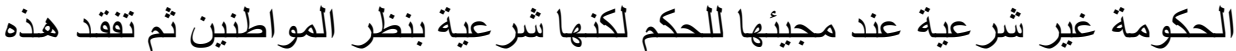
الثر عية بـالر غم تمتعهـا بالمشرو عية عن طريـق إقامـة دستور مثنل حكومـة تمـوز

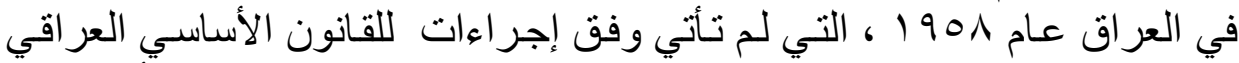

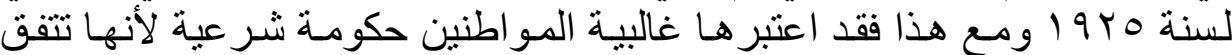
و الفكرة التي كان يقيمها العر اقيون حينذاك عن شر عية السلطة ثـ أقامـت دستور مؤقت فهي حكومة مشرو عة وبـالر غم من هذا بـأت تفقد شـر عيتها في نظر عدر عدد

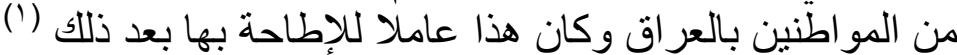
أما ما جرى في العراق فلا يمكن وصفه لا بالثورة و لا بالانقلاب لان الوسيلة

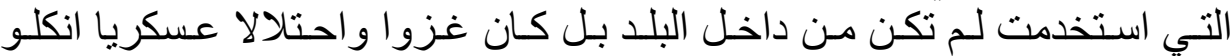
أميركي ، وضـع غطلاء لـه مجلس الحكم الذي لم يكن يملك أيـا من الصناحيات

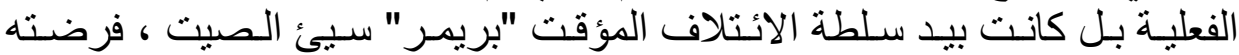
السلطات الأمريكيـة وفرضـت معـه وجـود مستشـار أمبركي بكل وزارة عر اقبـة

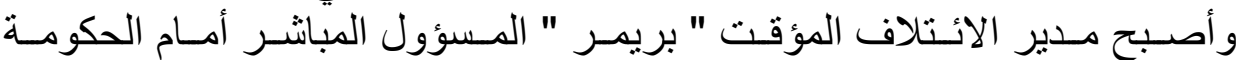

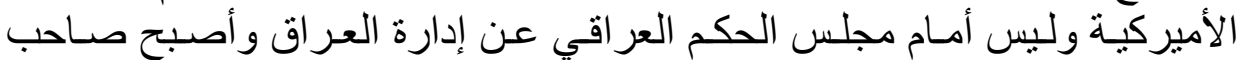

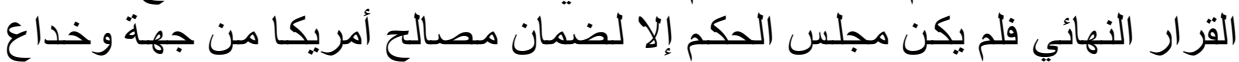

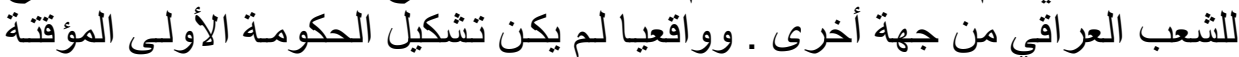
أي إشغال حقيقي للسلطات الإداريـة للعر اقيين ولـم يـؤدي وجود الحكومـة المؤقتة

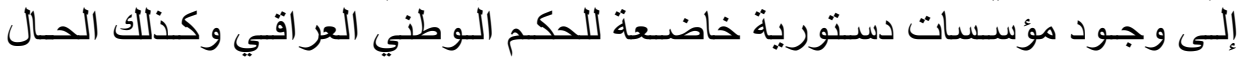

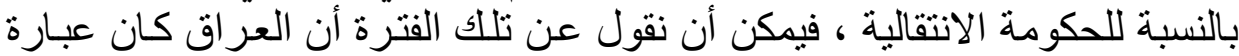
عن دولة ذات سبادة ناقصة و استقلال صوري خاضع لاحتلال عسكري و ماز ال .

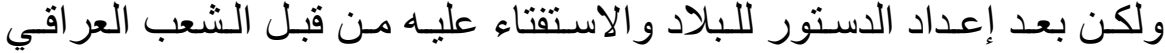
و إجراء الانتخابات التي شـار كيها فيا أكثر من ثمانية ملايين عر اقي وتشكيل مجلس

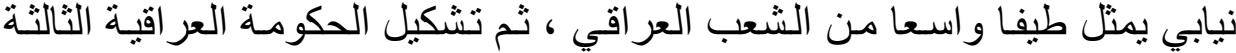

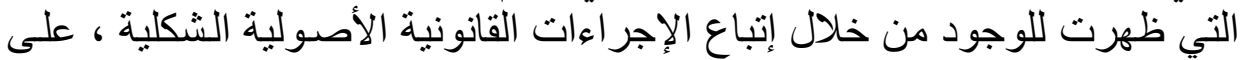
الر غم من وجود قوات الاحتلال بمكن أن نقول أنها حكومة شر عية ناقصة السيادة وذات و استقلال صوري الأمر كله بيد قوات الاحتلال وما يجري في العراق خيرٍ دليل على هذا هو التدخل السافر في الثأن العراقي الداخلي و الخارجي، خارقية وضناربةٌ بعرض الحائط جميع قو اعد القانون الدولي .

(') د. منذر الشاوي ، القانون الدستوري ، نظرية الدولة ، مصدر سابق ، صو V 


\section{itifi}

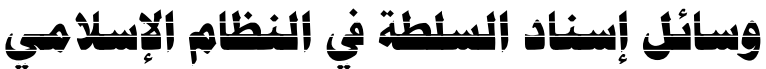

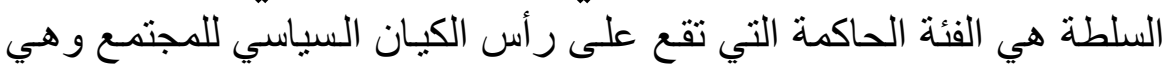

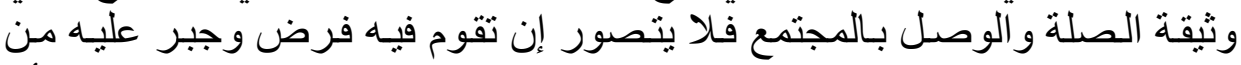

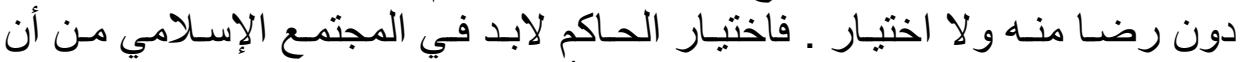

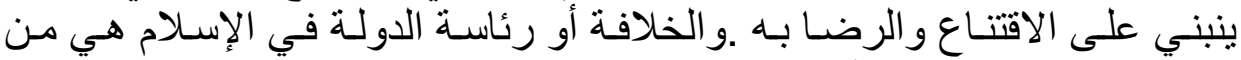

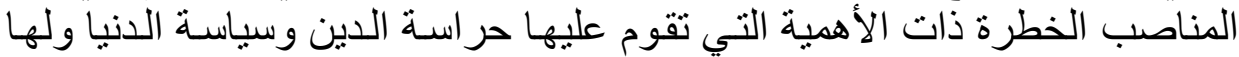

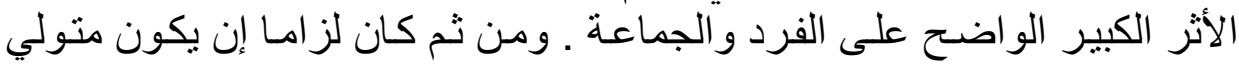

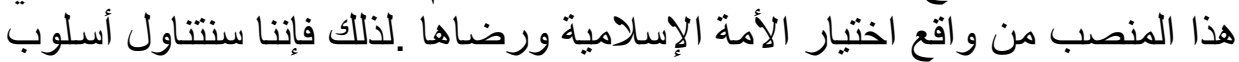

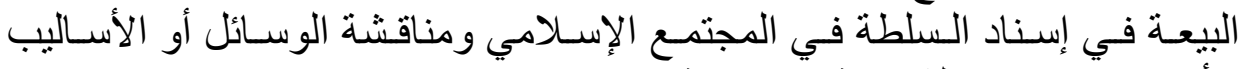
الأخرى في ضوء البردة الثر عية الإسلامية .

\section{| الثفرع الأولى}

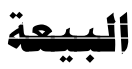

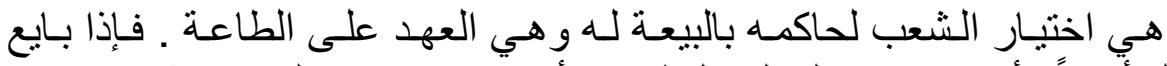

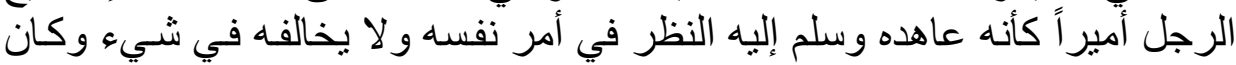

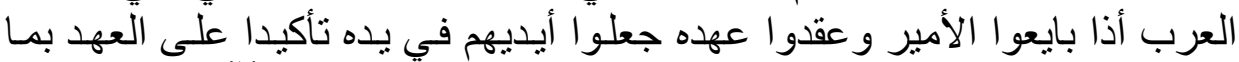

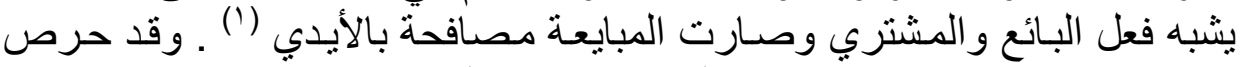

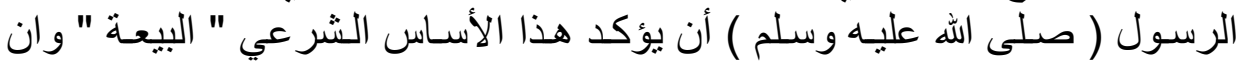

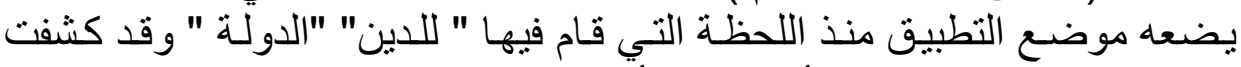

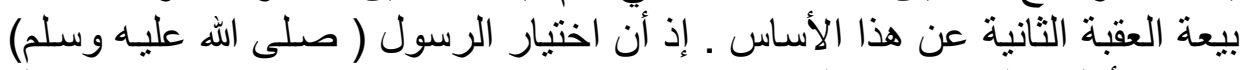

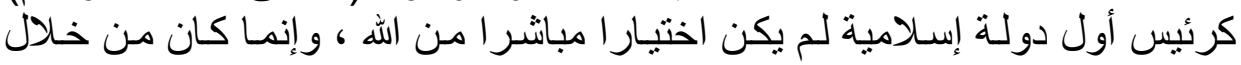

$$
\text { (') د. صبحي عبدة سعيد ، شرعية السلطة ، مصدر سابق ، صVV . . }
$$


بيعة الناس لله ، فجمع الرسول ( صلى الله عليه وسـلم ) بين الرسـالة التي كلفه الله

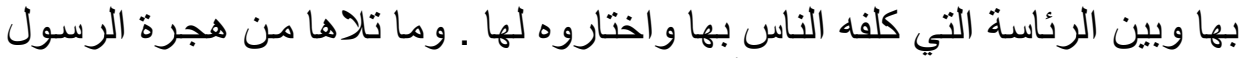

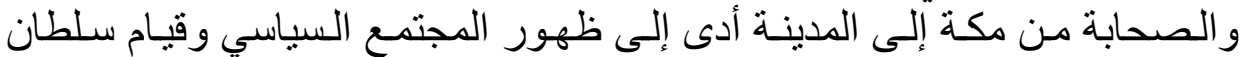

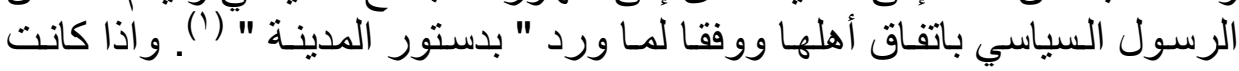

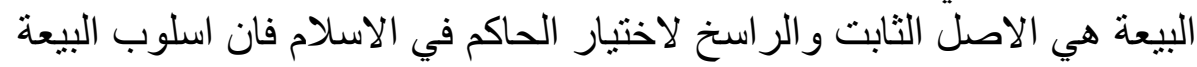

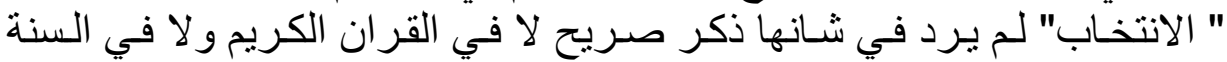

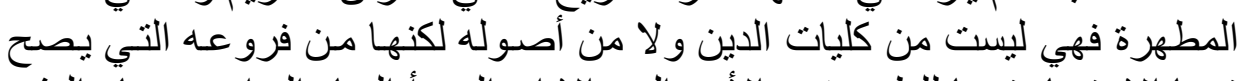

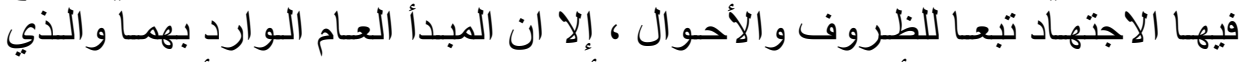

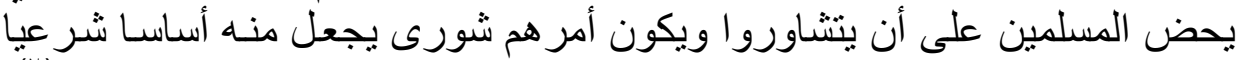

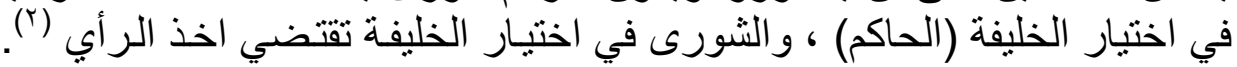

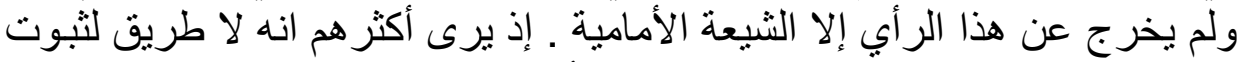

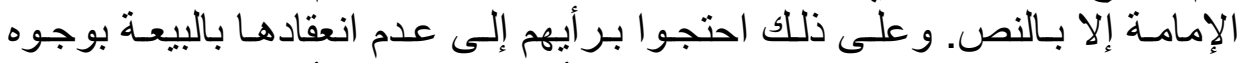

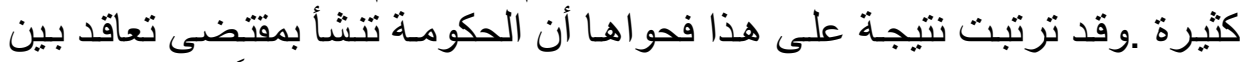

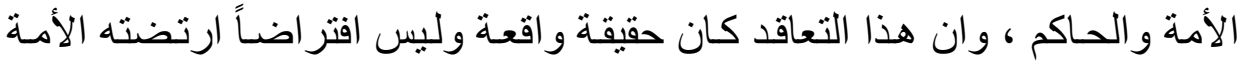

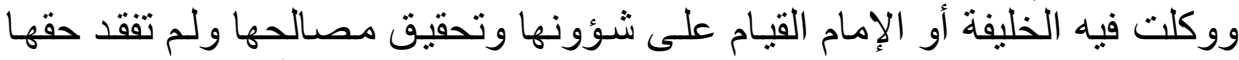

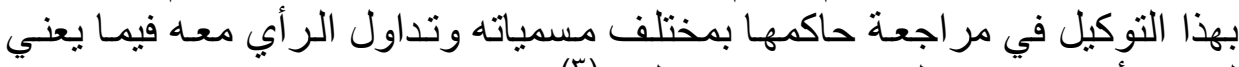

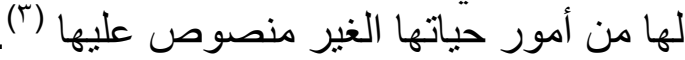

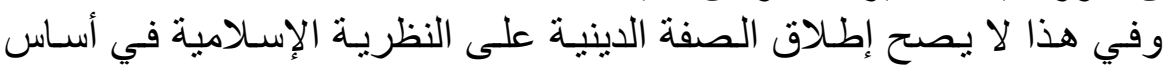

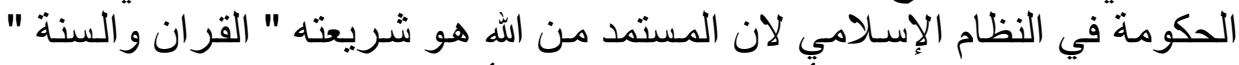

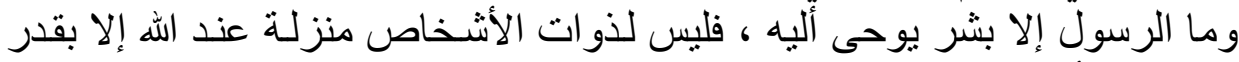

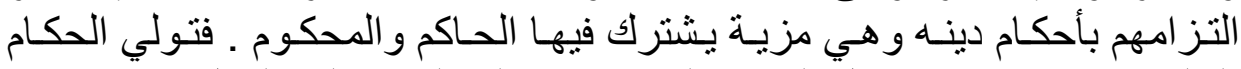

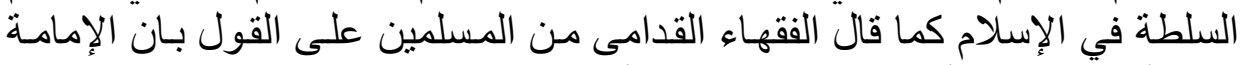

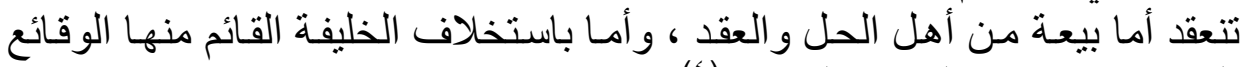

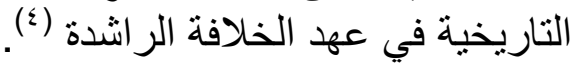

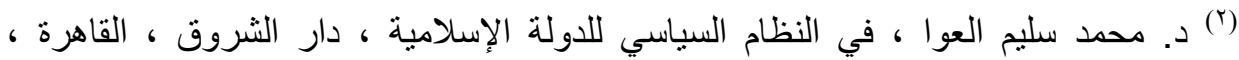

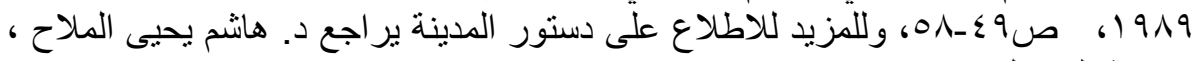

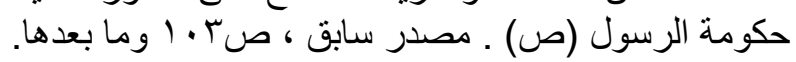

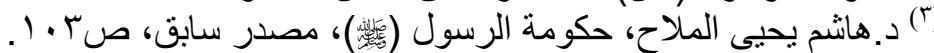

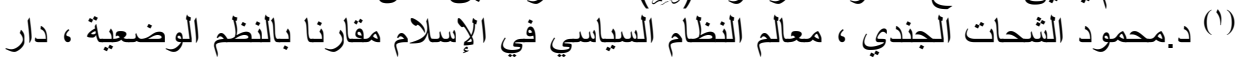

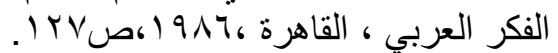

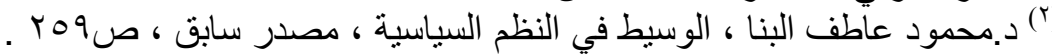




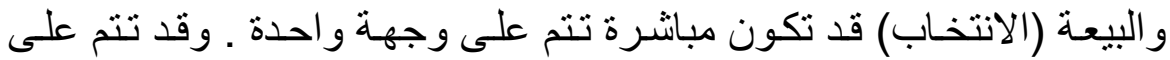

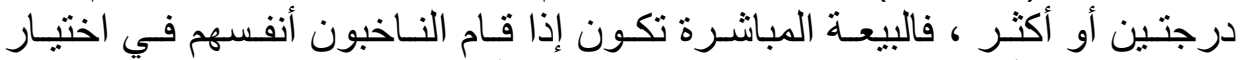

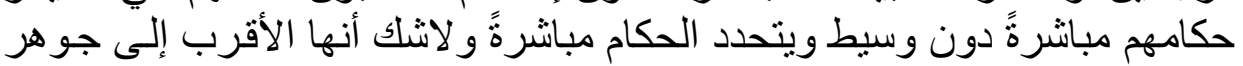

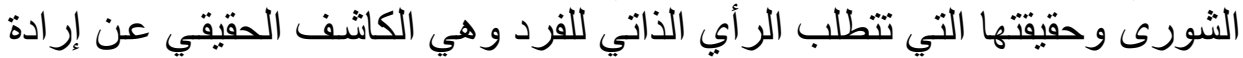

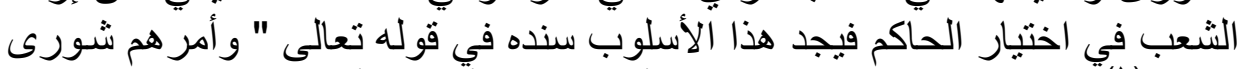

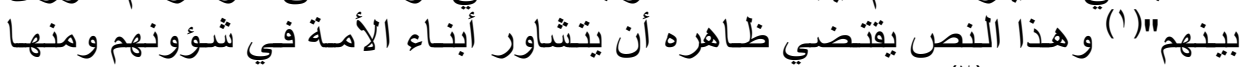

أختيار "الخليفة" (r) (ب)

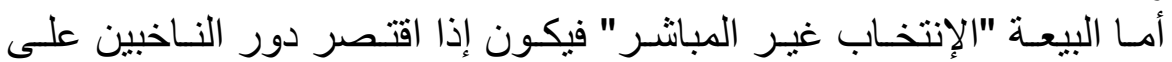

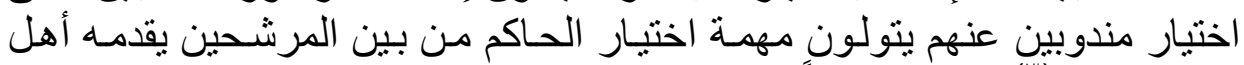

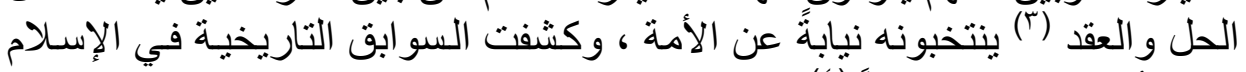

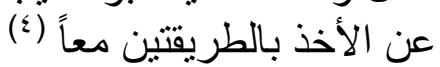

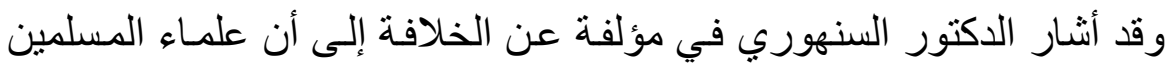

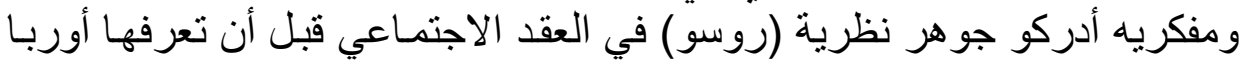

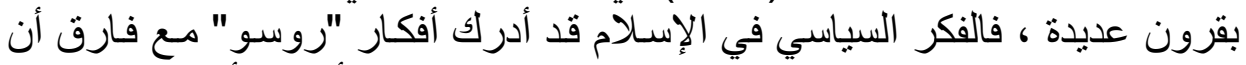

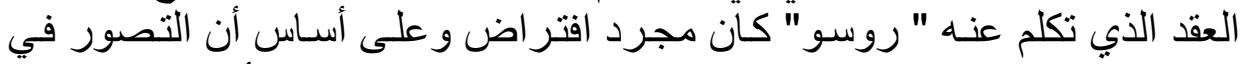

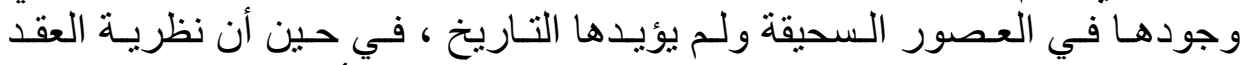

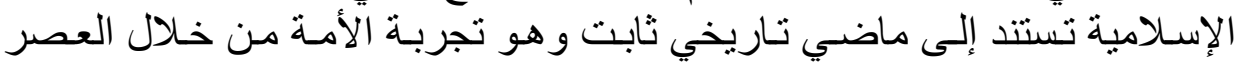

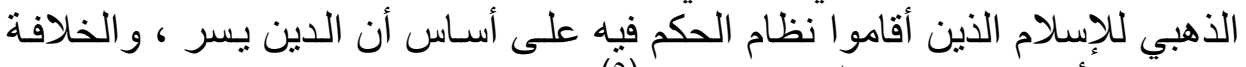

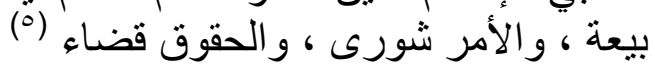

(ז) سورة الشورى آية عب.

(؛) د.صبحي عبدة سعيد ، السلطة والية الحرية في النظام الإسلامي ـ دراسة مقارنة ـ مصدر

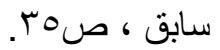

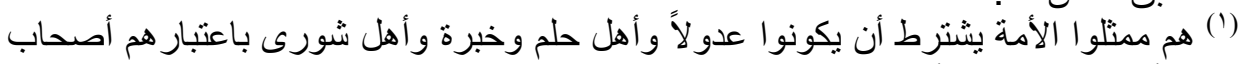

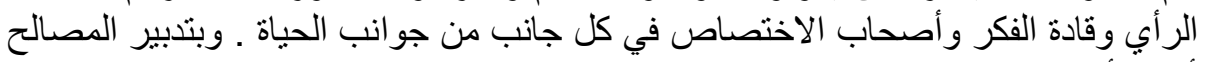

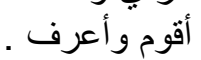

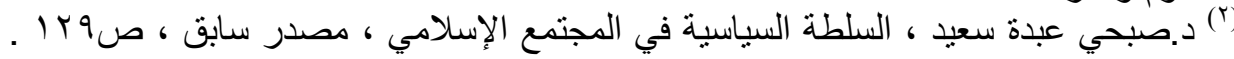

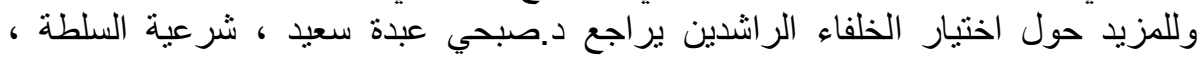

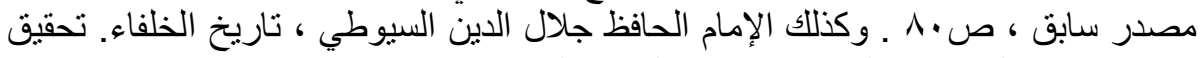

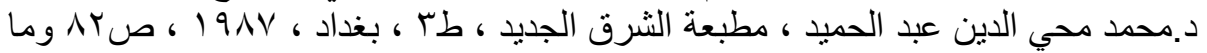
بعدها . دما

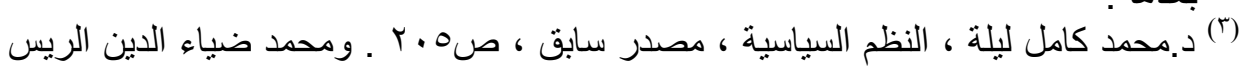

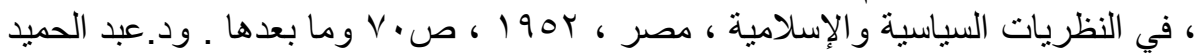




\section{|أنفرع أثناني}

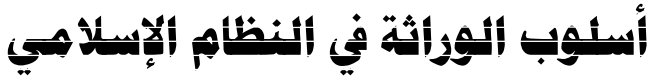

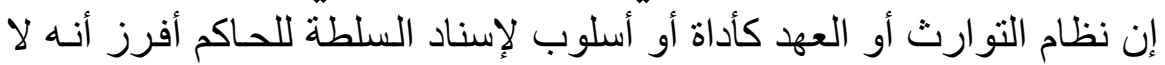

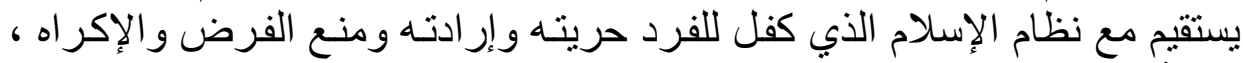

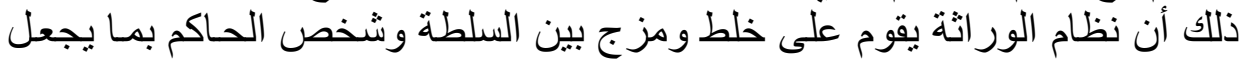

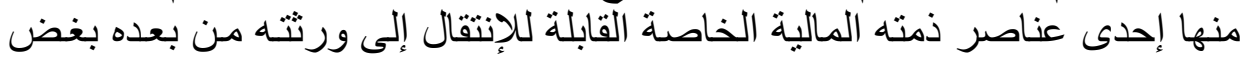

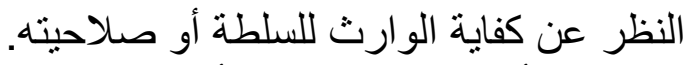

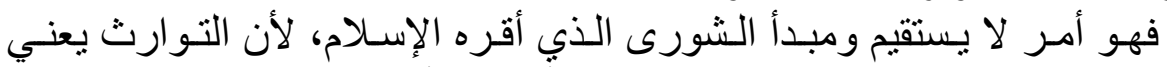

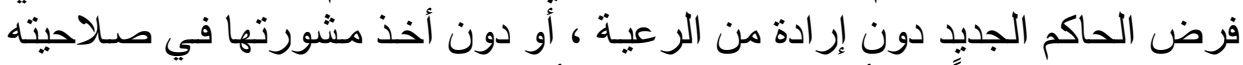

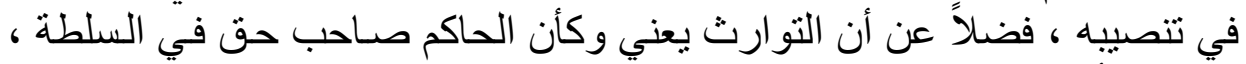

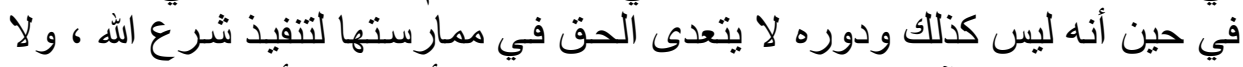

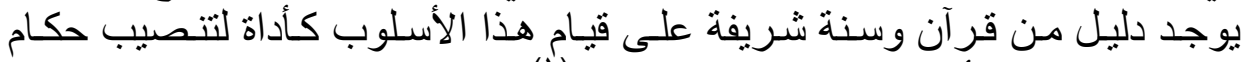

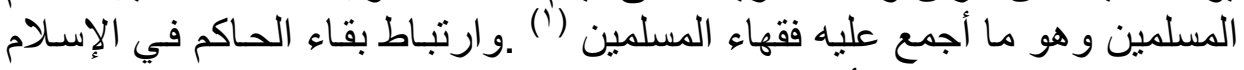

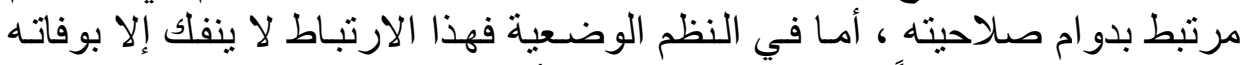

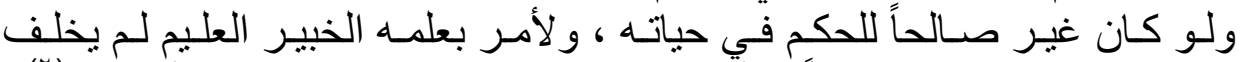

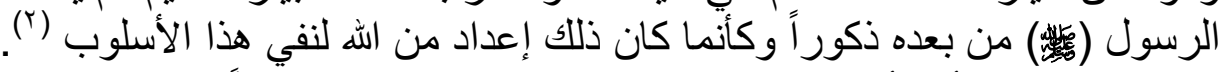

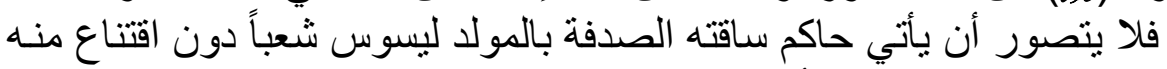

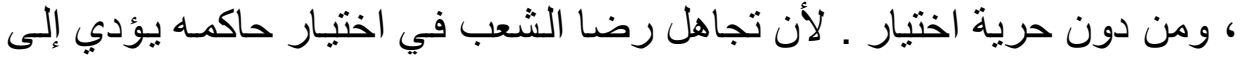

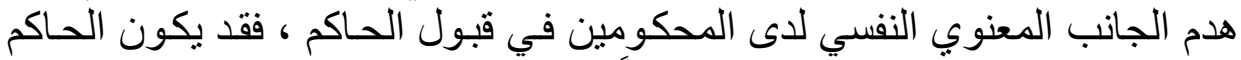

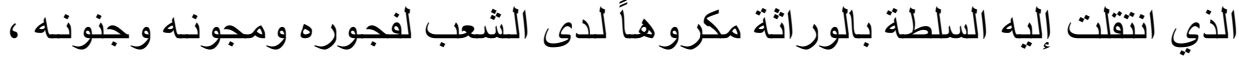

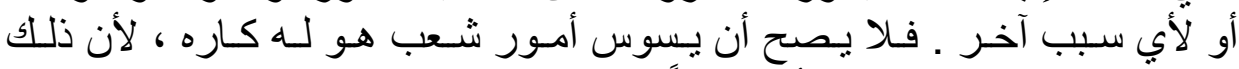

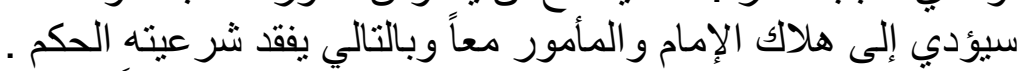

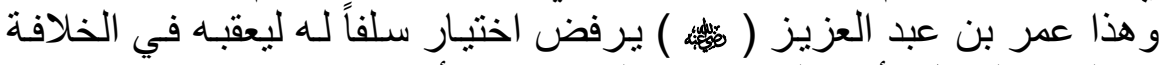

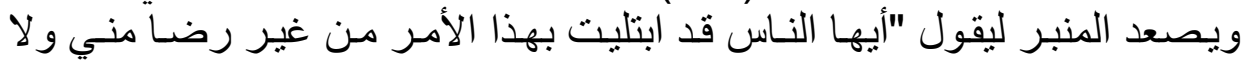

متولي ، مبادئ نظام الحكم في الإسلام ، طا ، دار الفكر العربي ، صب9؛؛ وما بعدها و

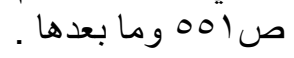

(') د.صبحي عبدة سعيد ، السلطة و الحرية في النظام الإسلامي ، دراسة مقارنة ، مصدر سابق ، صلصץ. د.صبحي عبدة سعيد ، السلطة السياسية في المجتمع الإسلامي ، مصدر سابق ، صVVI I . 
مشورة من المسلمين ، و إني قد خلعت مـا في أعناقكم من بيعة فاختاروا لأنفسكم

وبخلاف أر آء المذهب الجعفري يرى أن الدولة الإسلامية شهدت في التطبيق

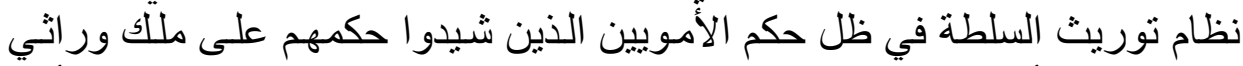

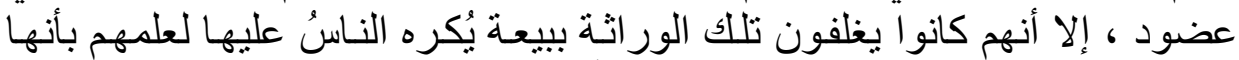

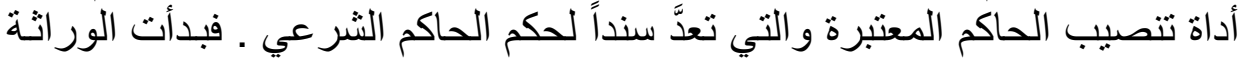

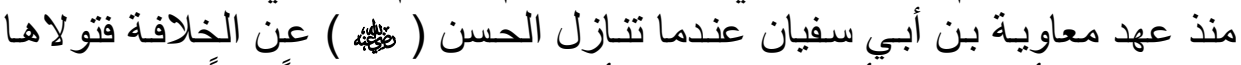

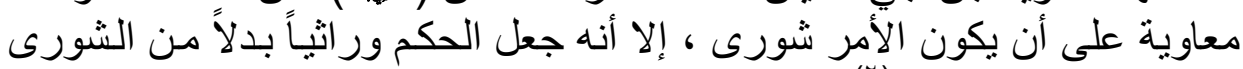

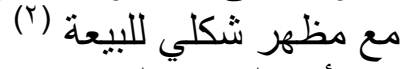

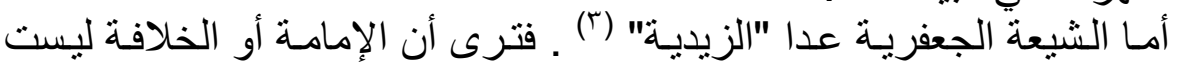

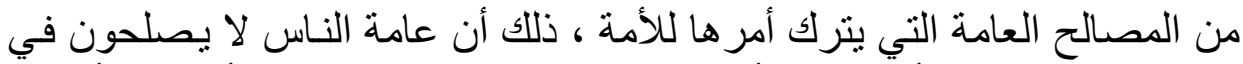

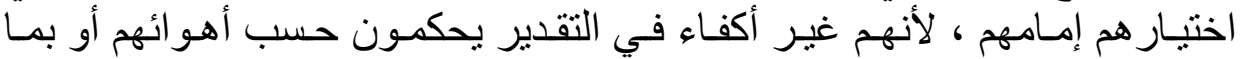

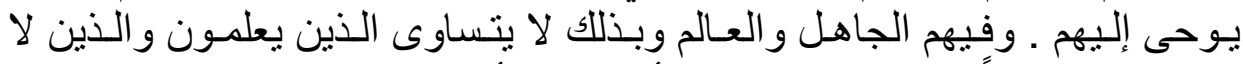

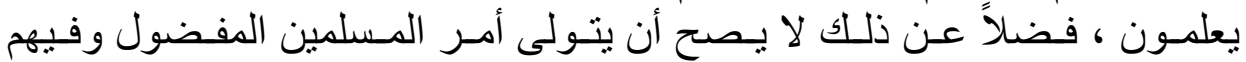

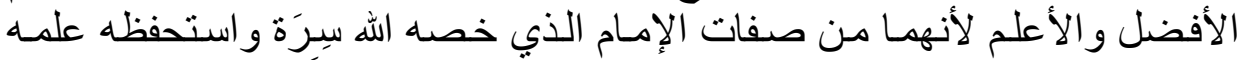

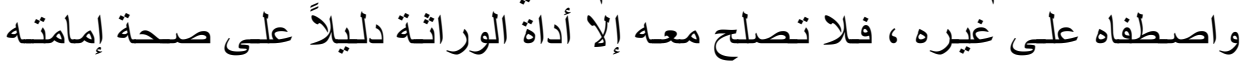

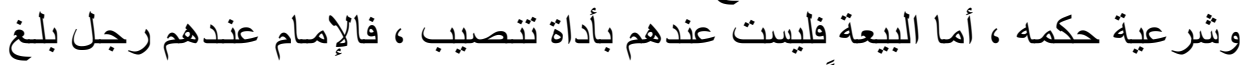

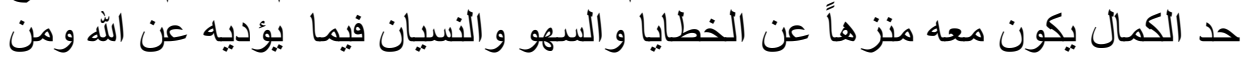

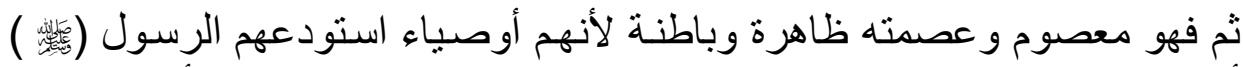

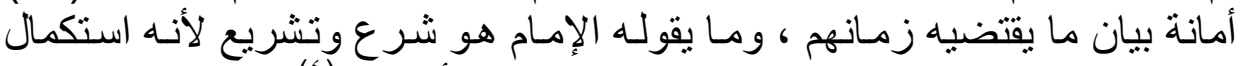

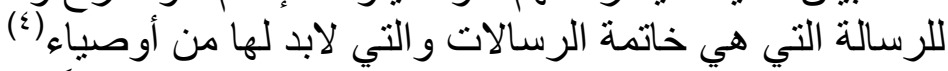

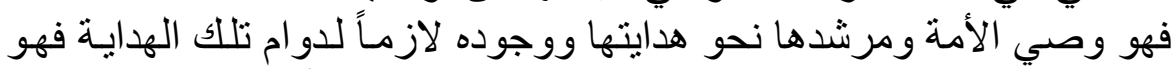

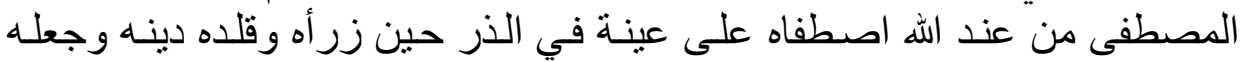

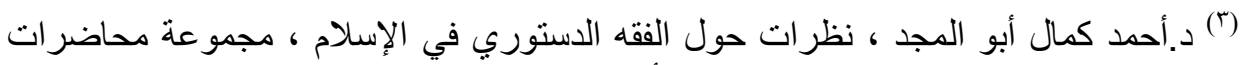

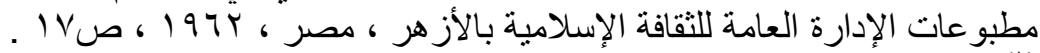

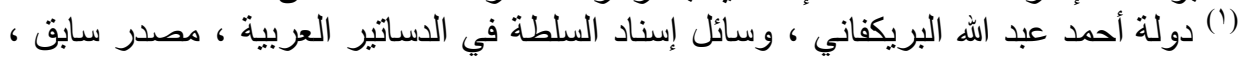

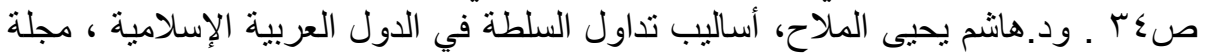

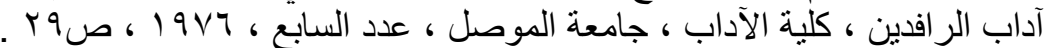

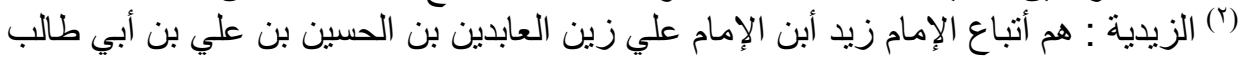

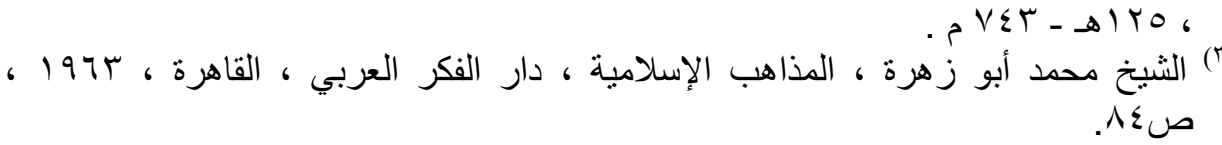




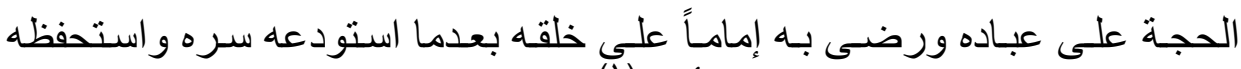

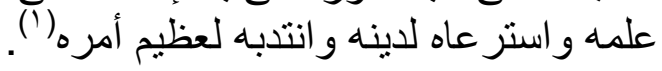

\section{ثfأif}

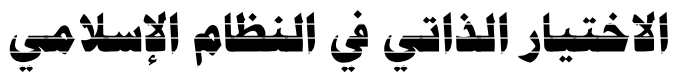

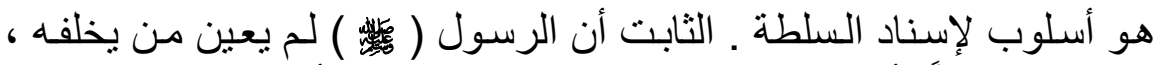

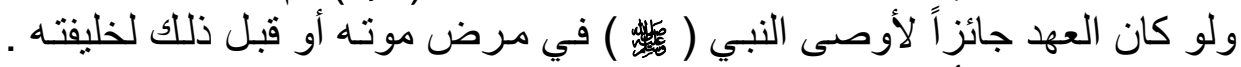

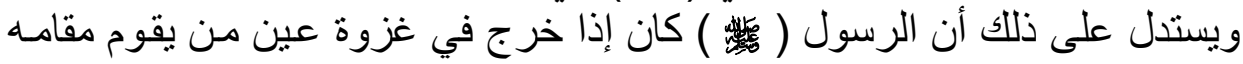

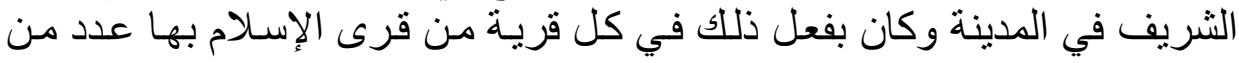

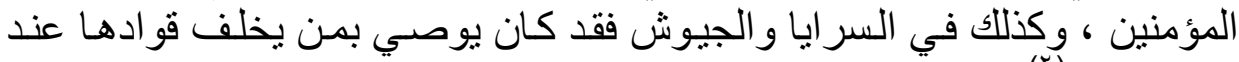

استشهادهم (r)

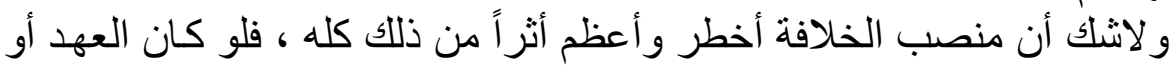

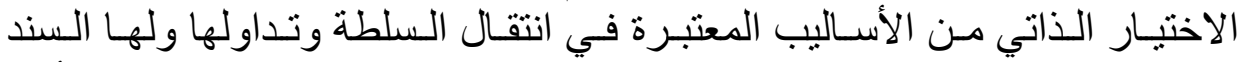

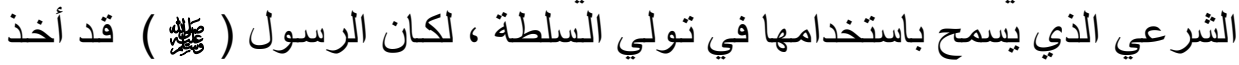

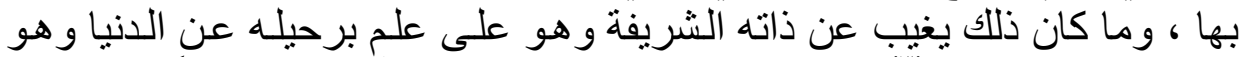

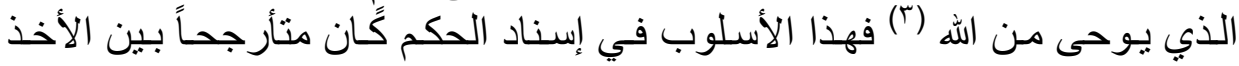

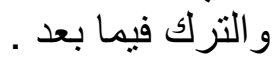
وكان الدافع إلى اختيار هذا الأسلوب في اختيار أبو بكر لعمر بن الخطاب فلم

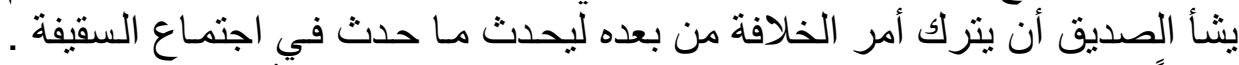

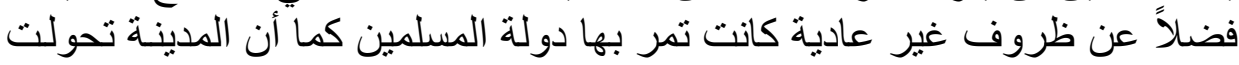

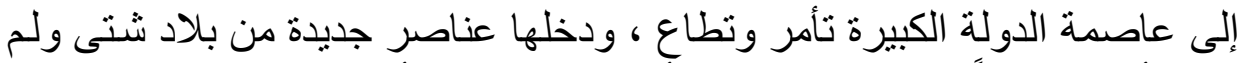

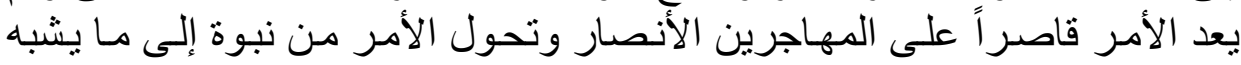

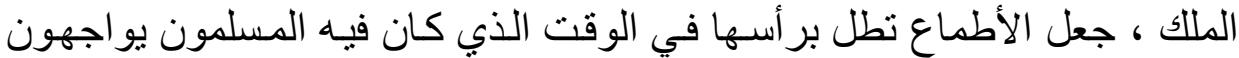

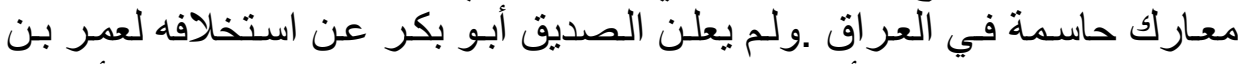

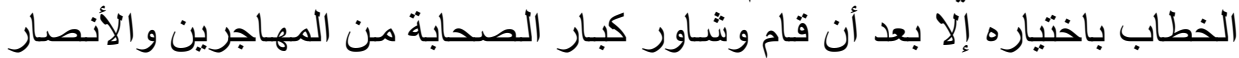

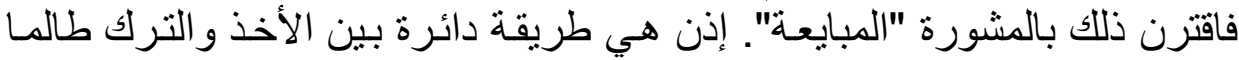

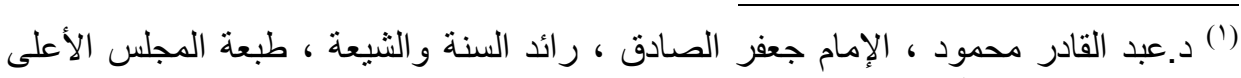

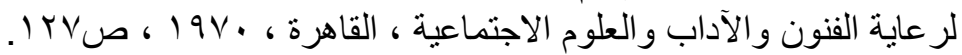

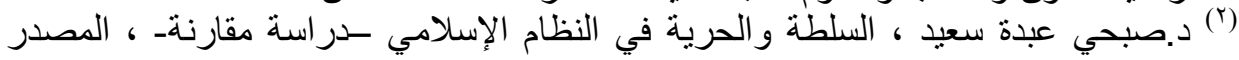

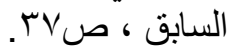
(r) د.صبحي عبدة سعيد ، شرعية السلطة و النظام الحكم في الإسلام ، المصدر السابق، صזي. 
تحققت مصلحة المسلمين في ذلك وطالمـا أحيطت بضمانات شر عية بحيث تكون للإر ادة الثعبية القول و الفصلّ ابتداءً (').

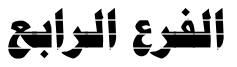

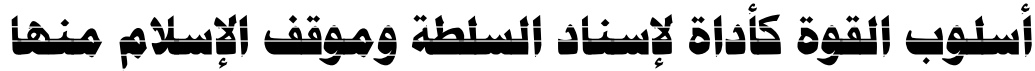

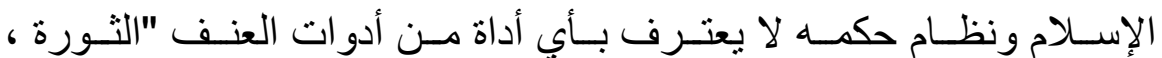

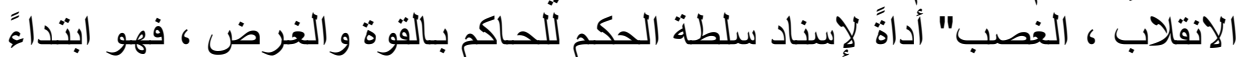

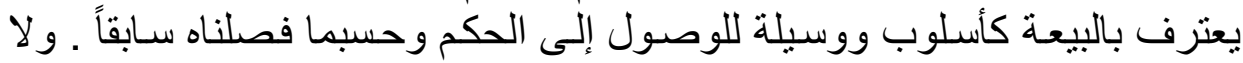

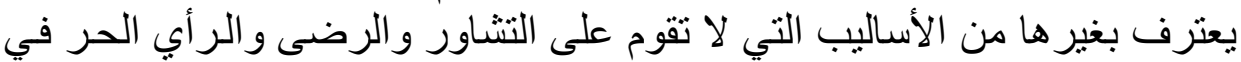

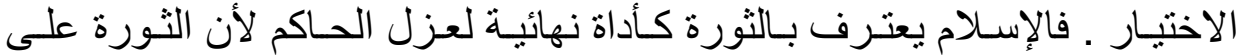

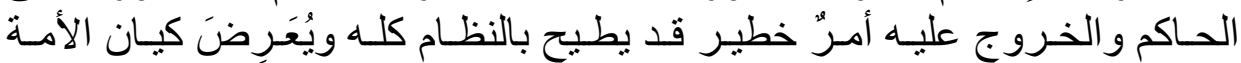

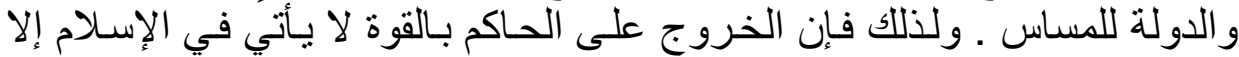

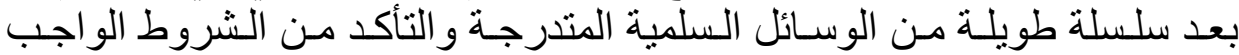

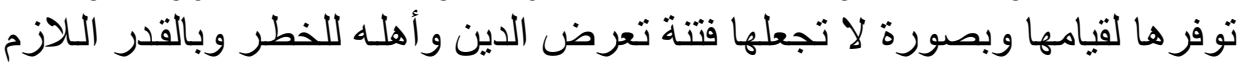

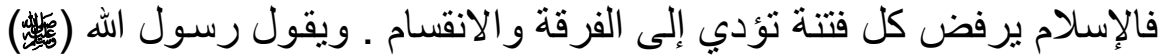

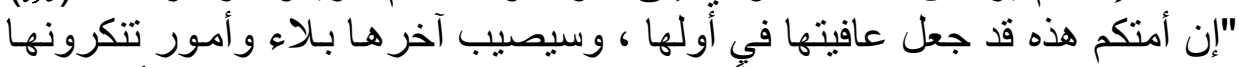

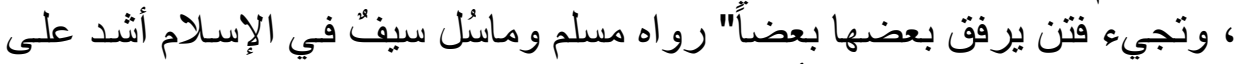

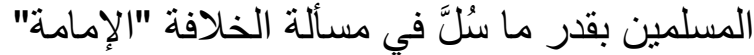

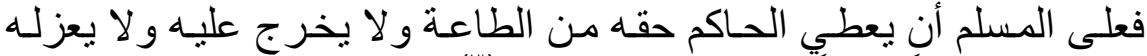

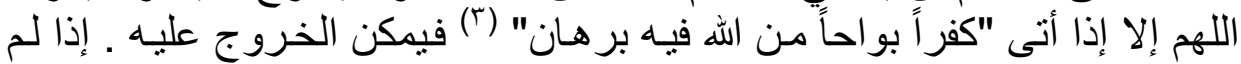

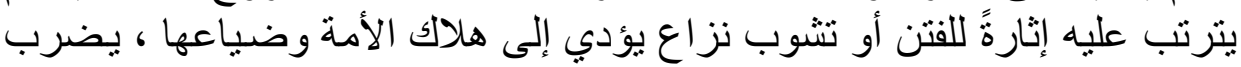

(') راجع تفاصيل أكثر من اجتماع السقيفة د.صبحي عبدة سعيد ، المصدر السابق ، ص اه وما

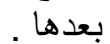
(؟) د.صبحي عبدة سعيد ، السلطة والحرية في النظام الإسلامي ـ دراسة مقارنة - ، المصدر

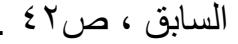

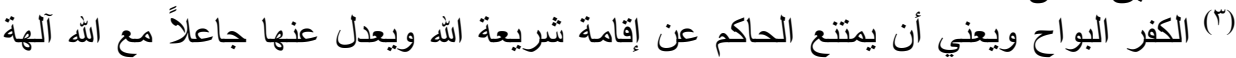

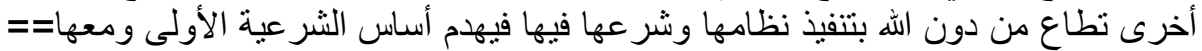

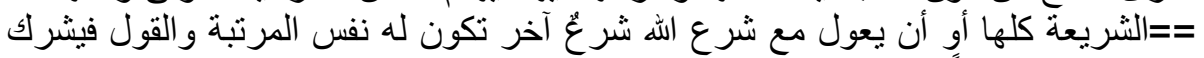

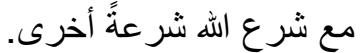




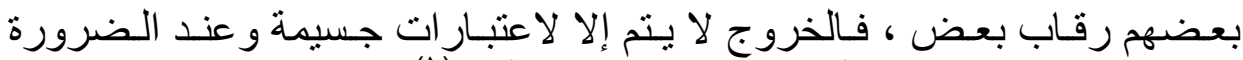
القصوى لتحمل الضرر الأدنى لتفادي الضرر لألتهرو الأكبر (').

inifi|f

بعد ان انتهينا من كتابة بحثنا توصلنا الى النتائج الاتية:

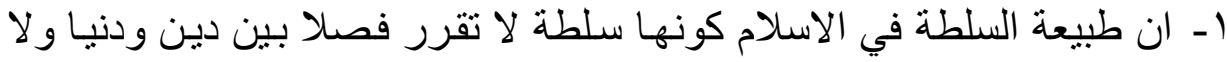

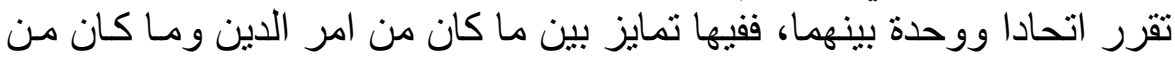

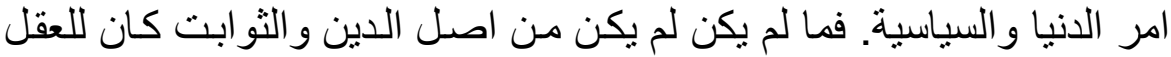

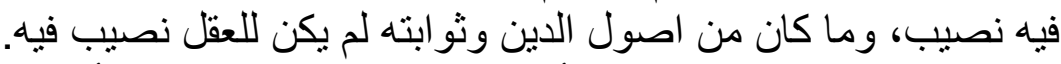

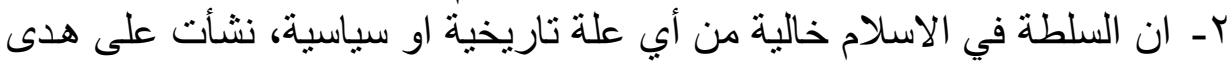

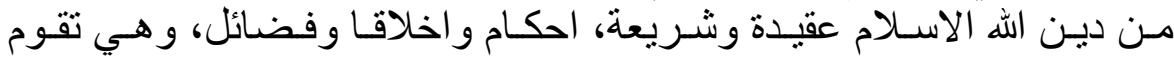

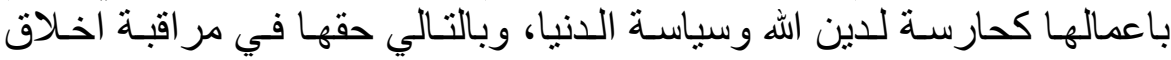

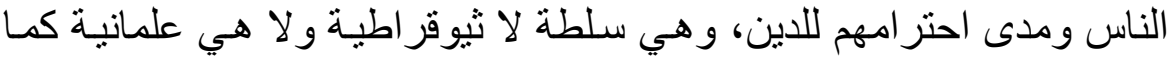
في النظم الوضعية.

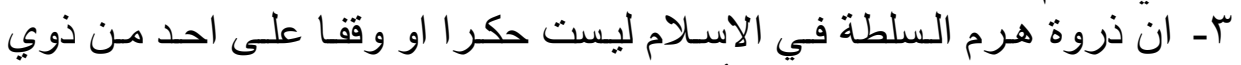

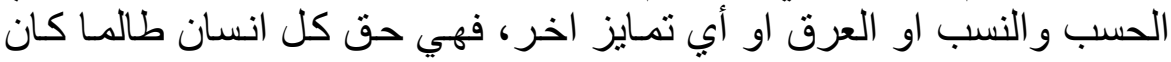

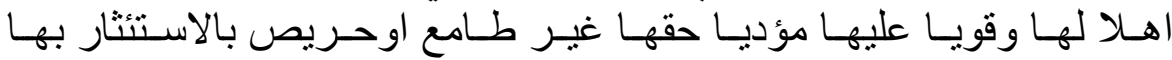

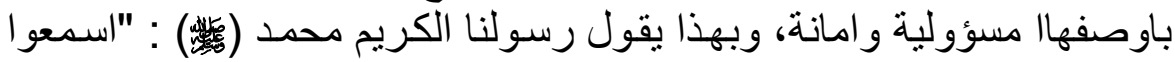

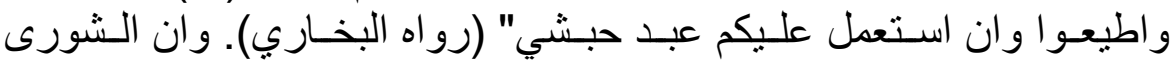

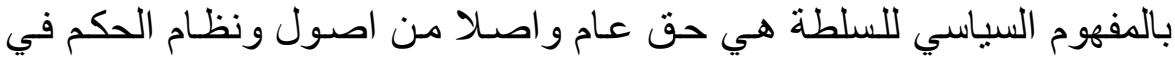

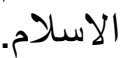

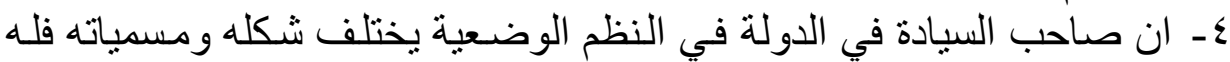

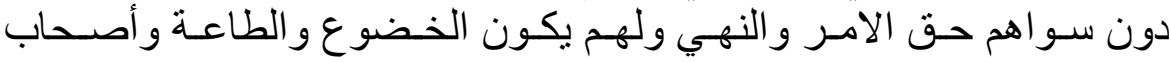

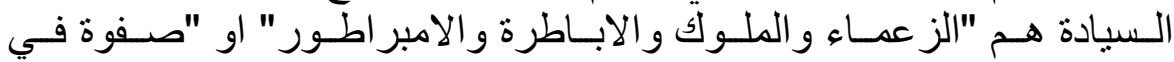

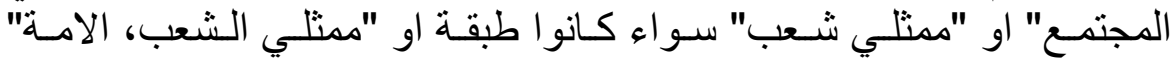

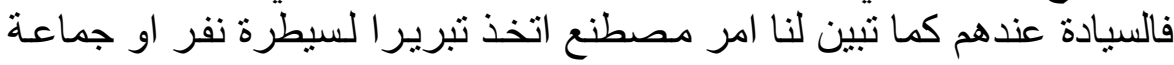

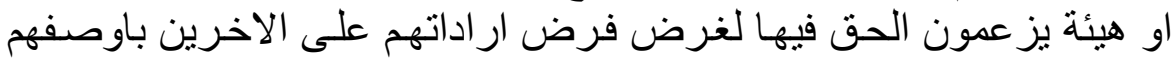

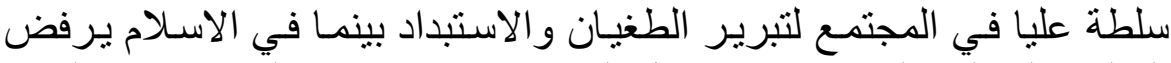

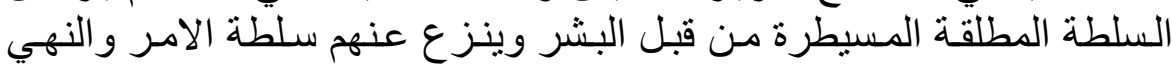

(1) د.صبحي عبدة سعيد ، السلطة السياسية في المجتمع الإسلامي ، المصدر السابق ،صع؟1 


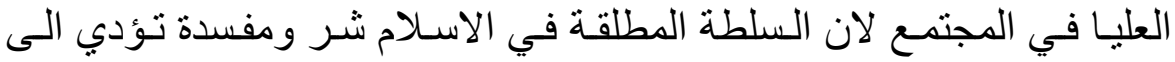

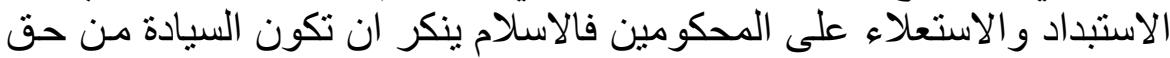

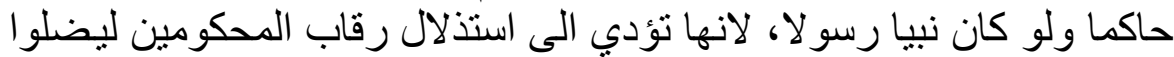

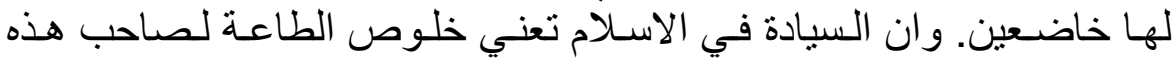

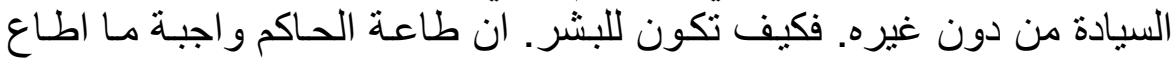

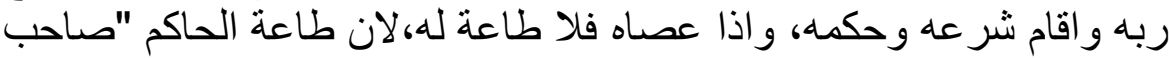

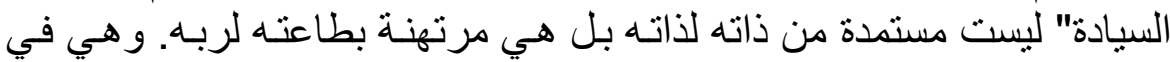

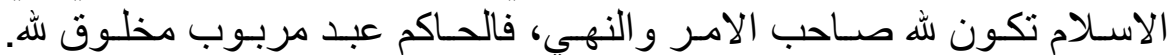

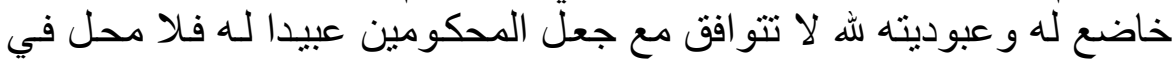

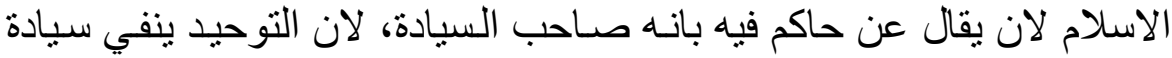

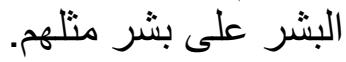
0ـ ان الاسلام يرفض صنيغ الدولة والسياسية بالصبغة الدينية. فهو يرفض فئن فكرة

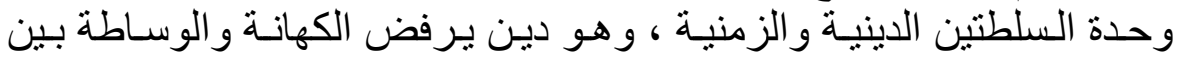

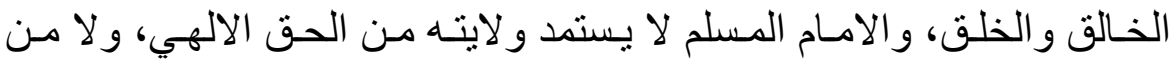

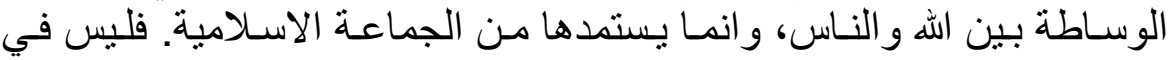

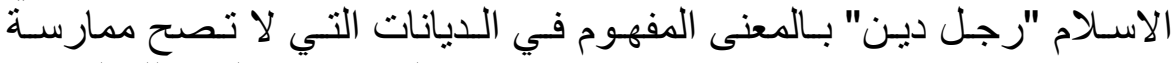

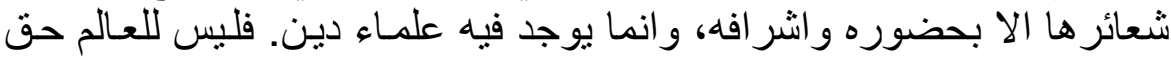

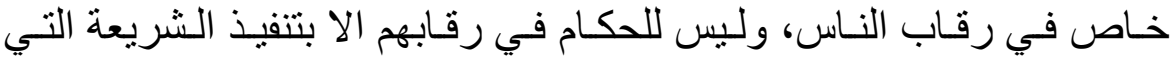

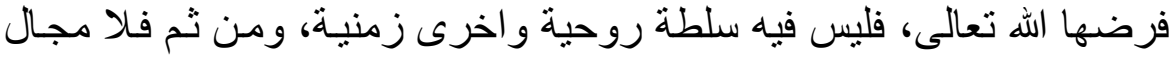

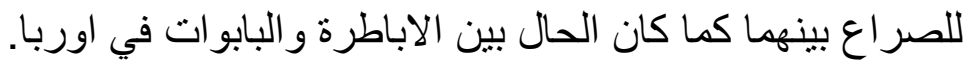

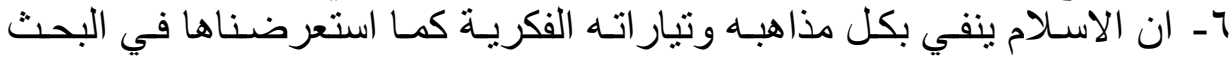

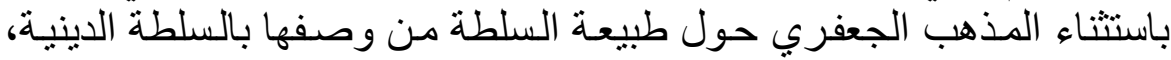

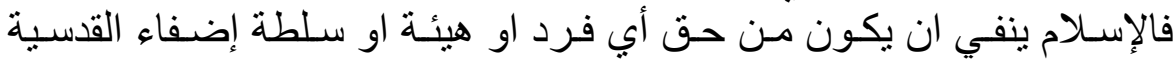

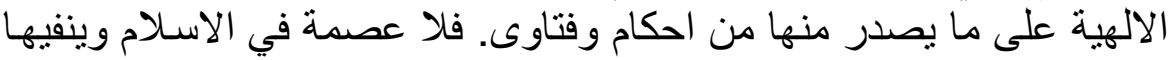

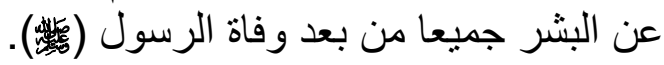

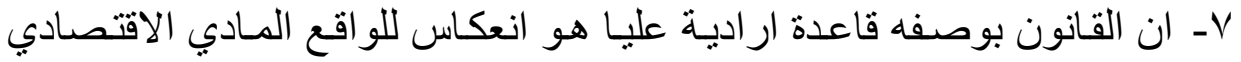

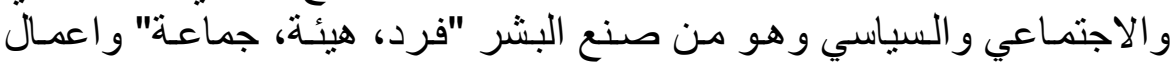

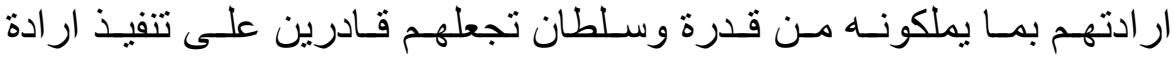

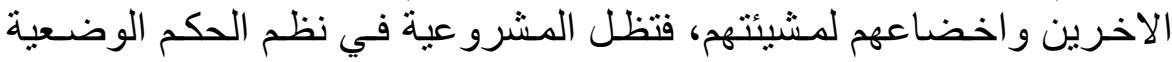

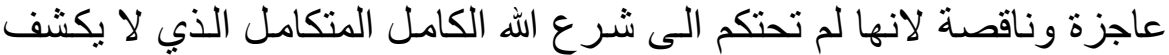

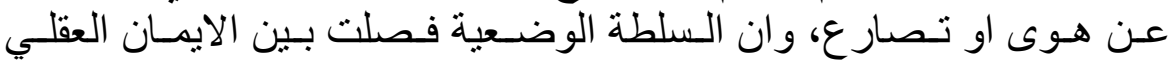

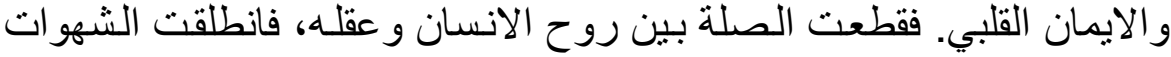




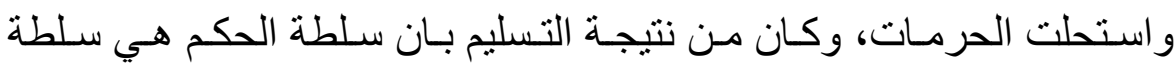

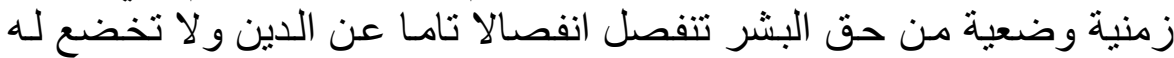

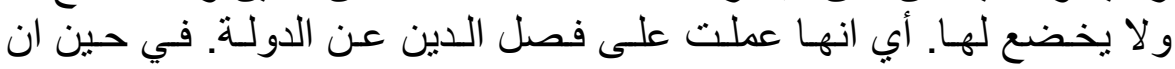

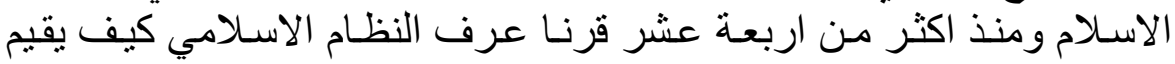

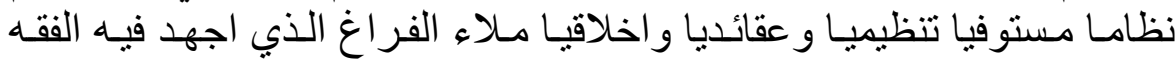

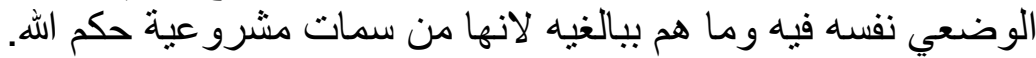

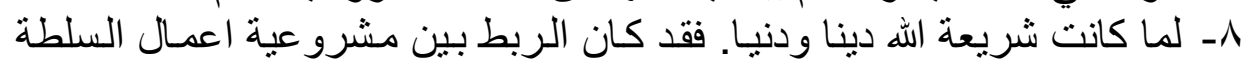

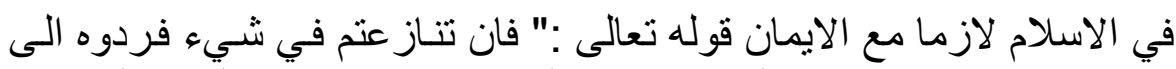

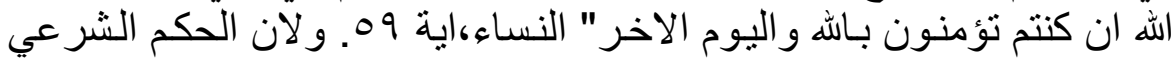

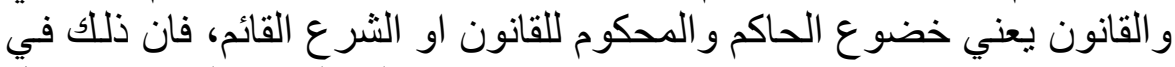

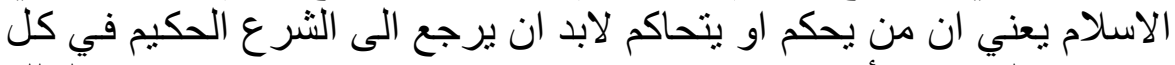

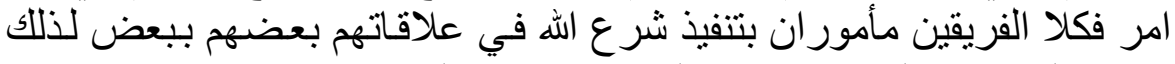

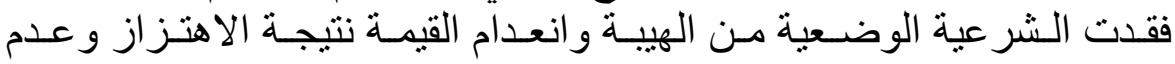

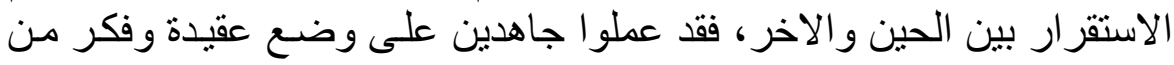

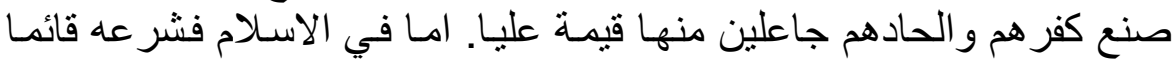

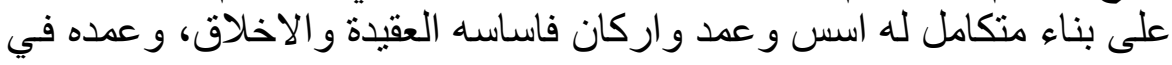

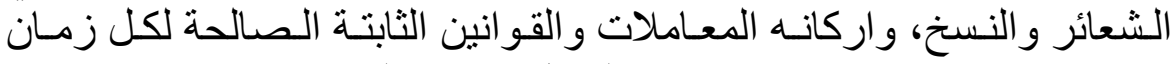

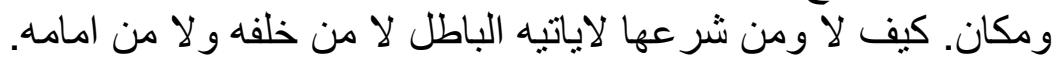

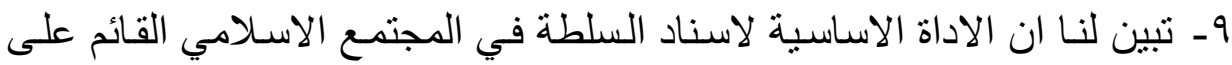

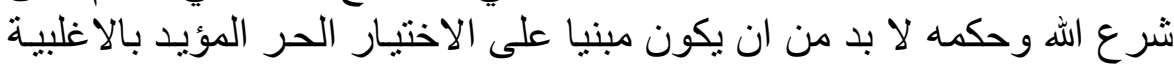

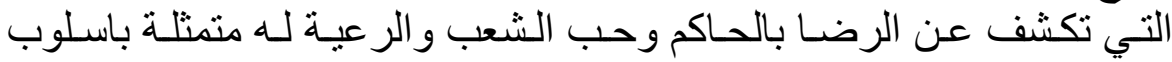

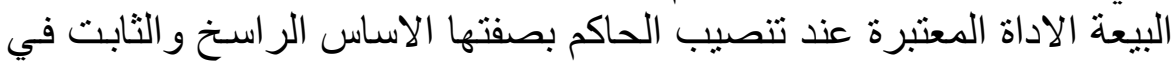

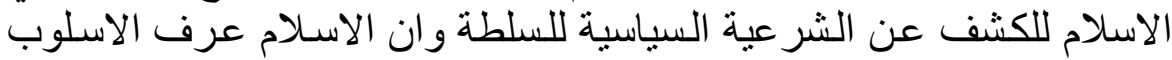

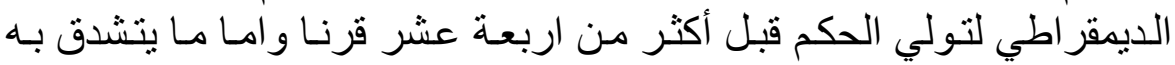

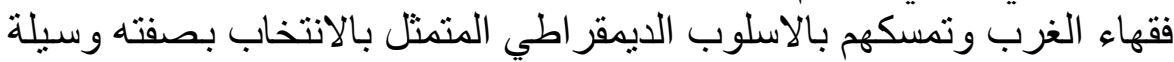

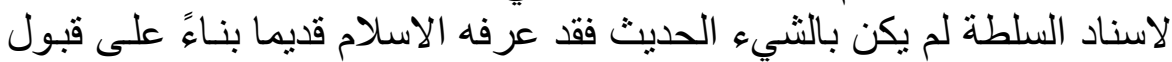

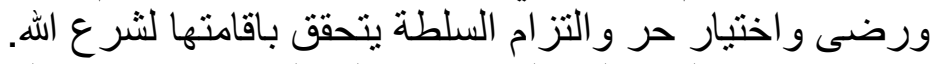

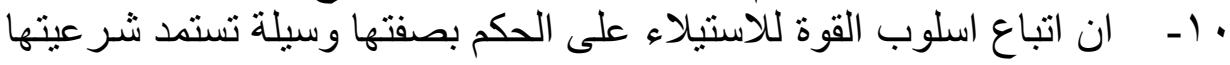

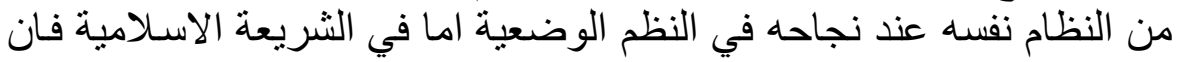

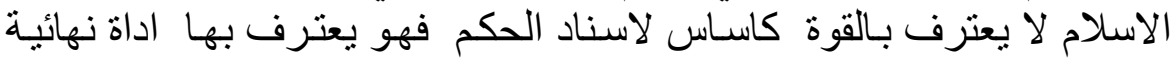

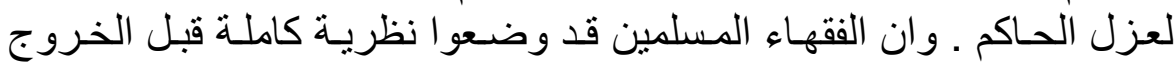

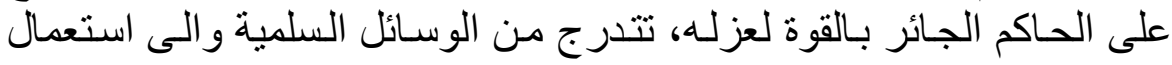


القوة كحل اخير وضـروري حفاظـا على الامـة مـن الفتــة وضـياع شـر ع الله

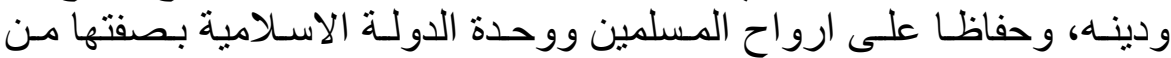

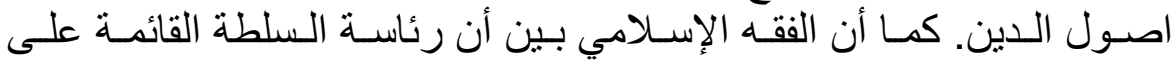

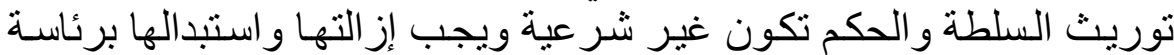

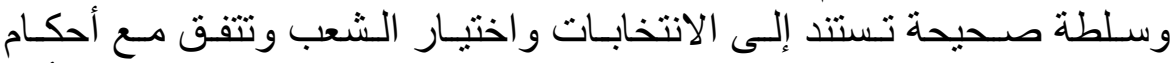

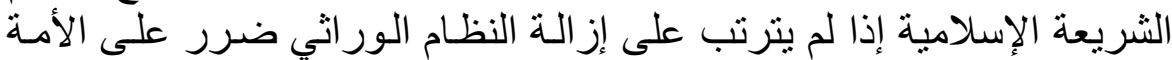

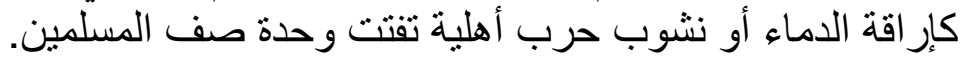

القرآن الكريم

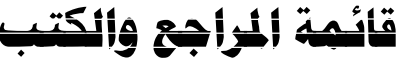

ا . الحافظ جلال السيوطي ، تاريخ الخلفاء تحقيق محمد محي الدين عبد الحميد ،

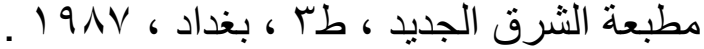

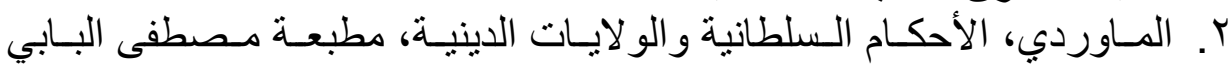

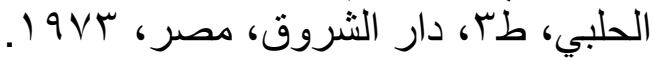

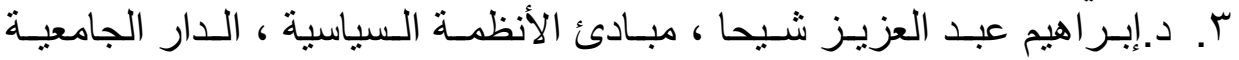

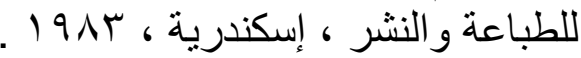

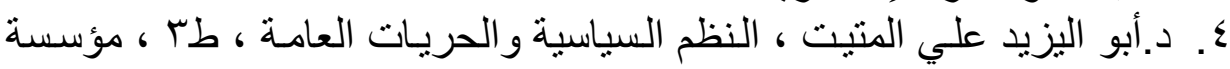

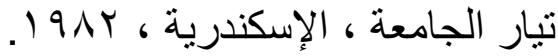

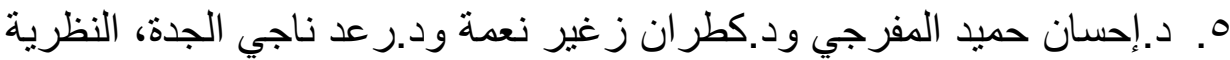

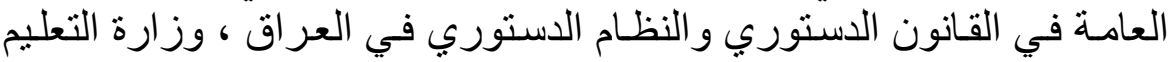

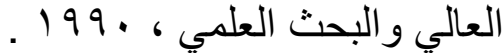

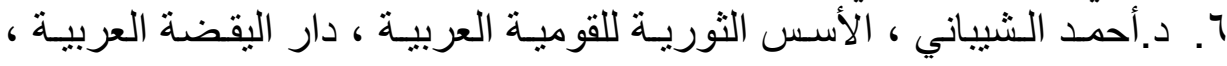
دمشق

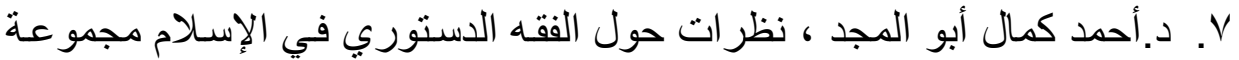

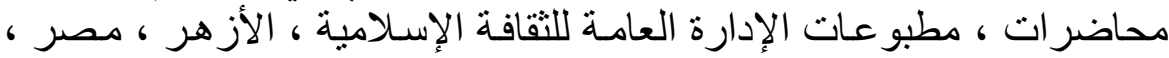




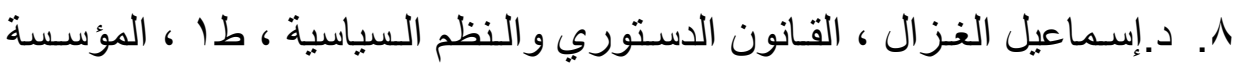

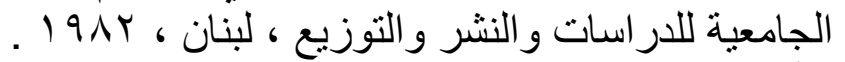

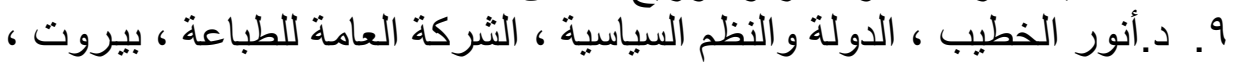
.19V.

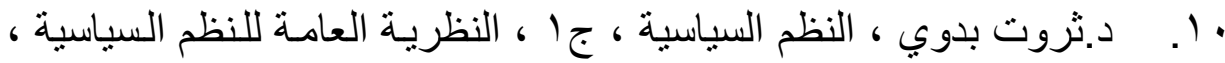

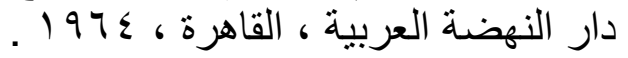

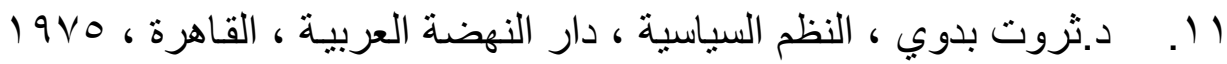
Y ا. د.حسين عثمان محمد عثمان ، النظم السياسية والقانون الدستوري، الدار

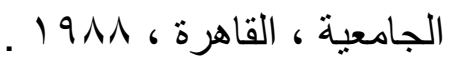

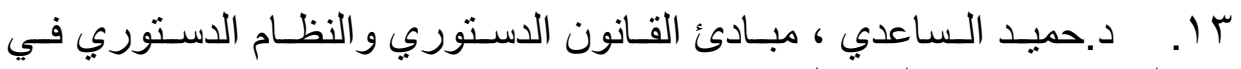

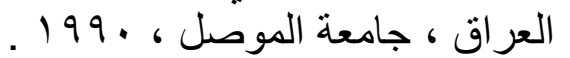

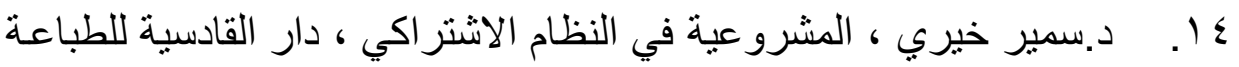

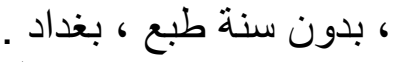
10. د.شمر ان حمادي ، النظم السياسية ، طب ، دار الحريـة للطباعة ، بغداد ، 19VT

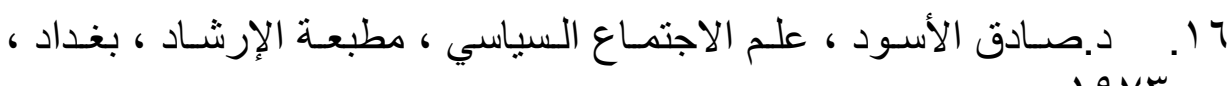
$.9 \mathrm{VT}$

V ا. د.صبحي عبدة سـعيد ، الحساكم وأصـول الحكم في الإسـلام ، القـاهرة ، .1910

11. دو د.صبحي عبدة سعيد ، السلطة السياسية في المجتمع الإسلامي ، القاهرة ، .1991

19. د. د.صحي عبدة سعيد ، السلطة في المجتمع الاشتر اكي ، القاهرة .

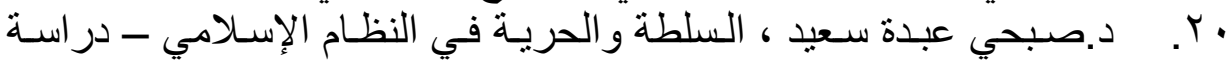

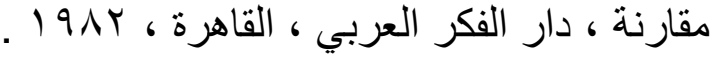

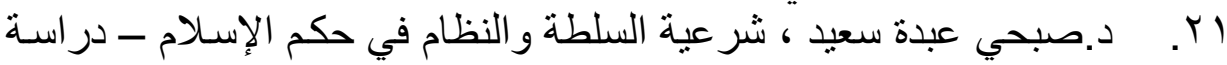

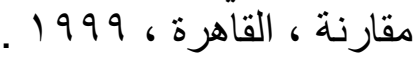

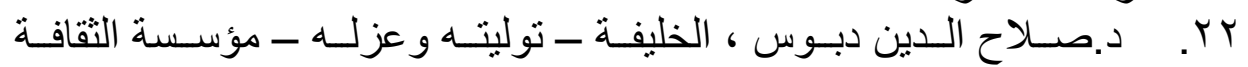

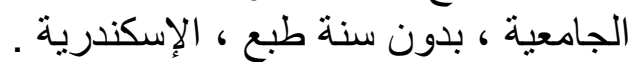

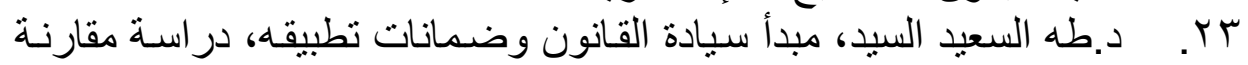

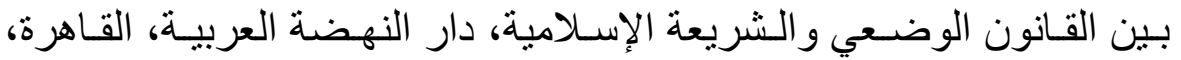




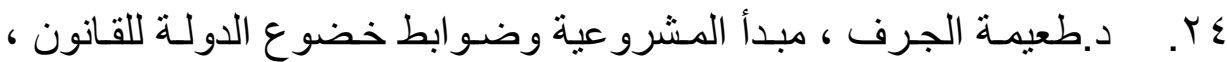

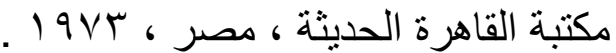

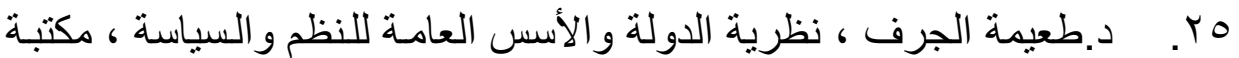

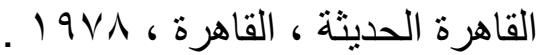

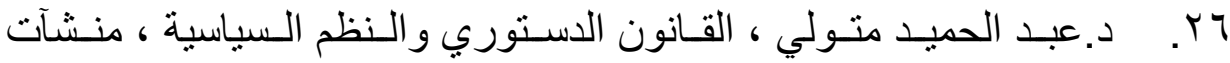

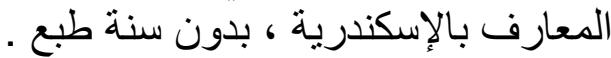

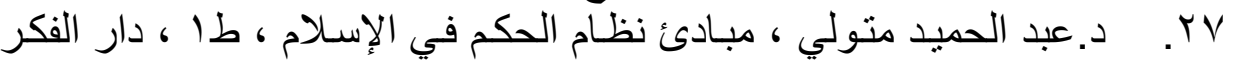

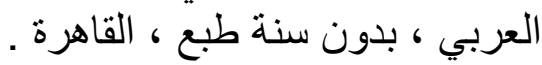

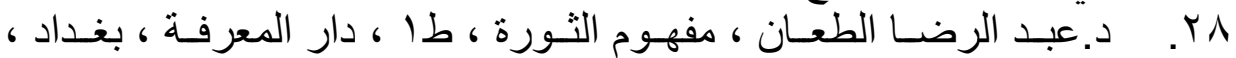
.191 .

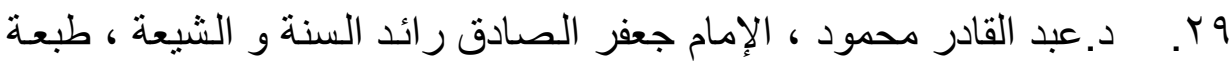

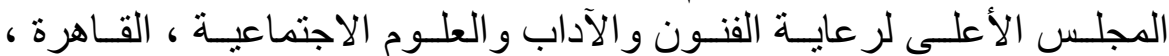
$.19 \vee$.

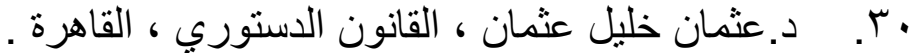

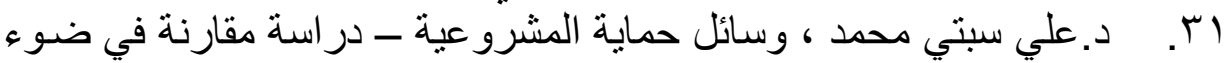

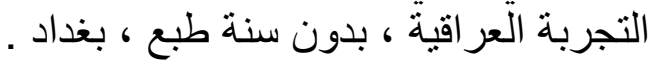

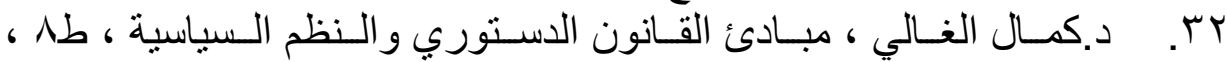

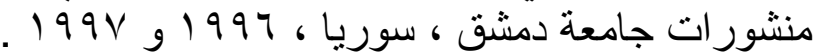

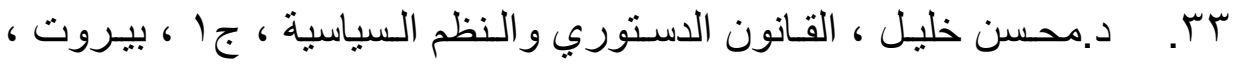
$.191 \mathrm{~V}$

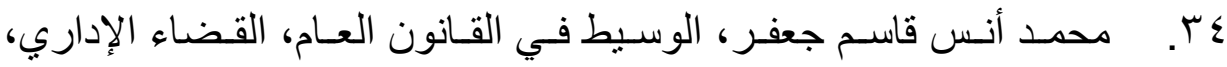

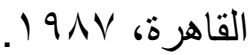

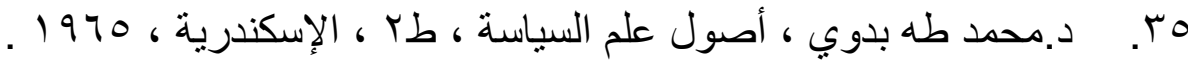

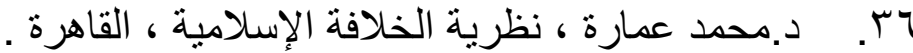

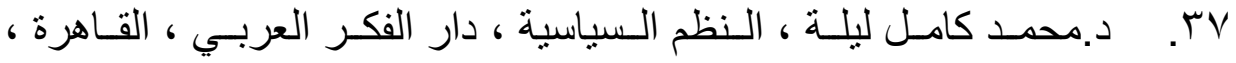
$19 \times 1$

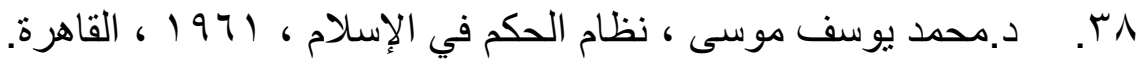

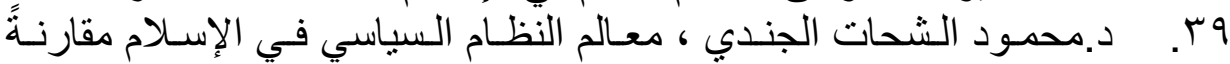

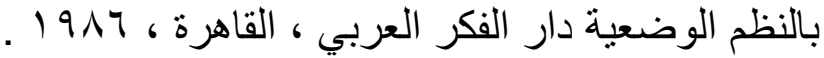

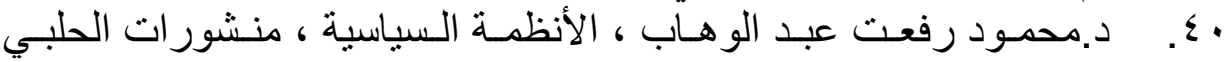

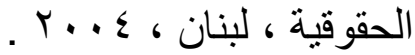




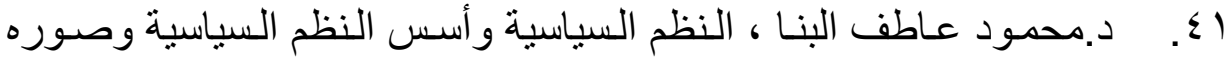

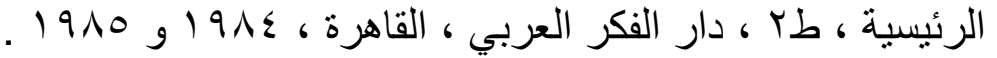

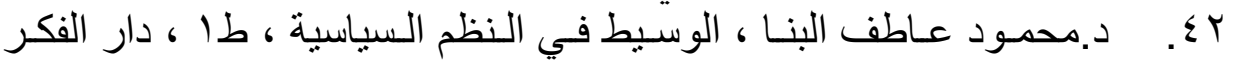

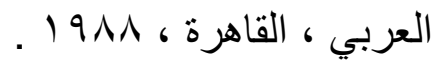

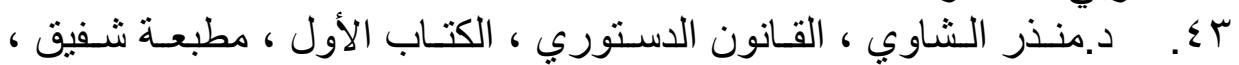
بغداد ، $197 V$

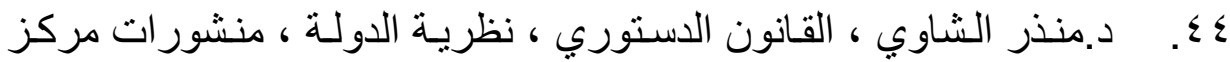

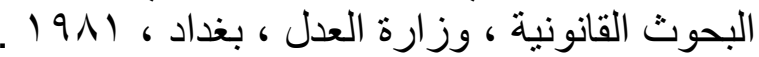

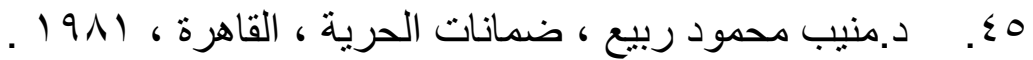

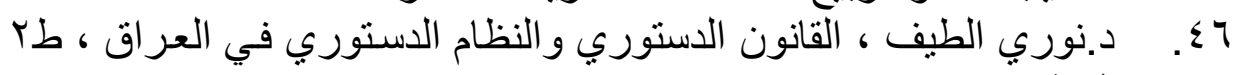

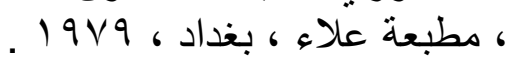

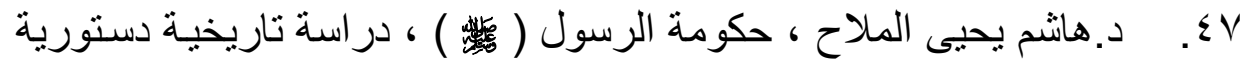

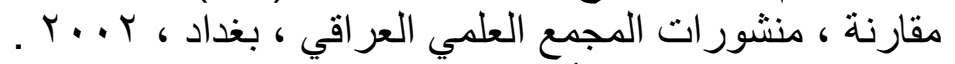

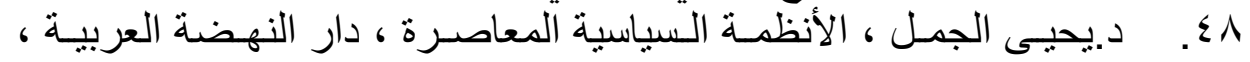
القاهرة.

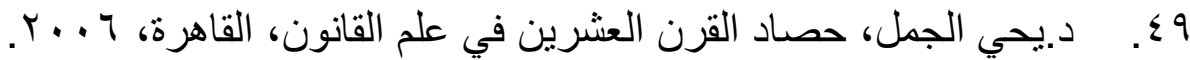

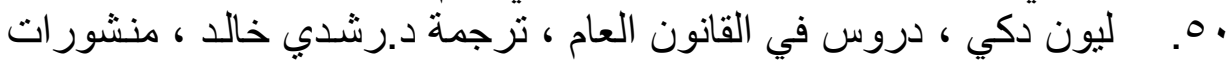

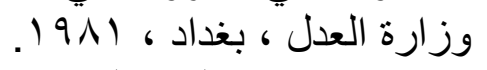

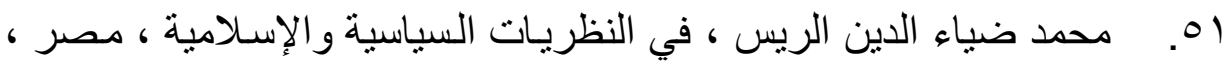
.1904

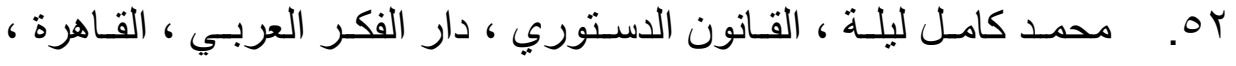
$.19 V \varepsilon$

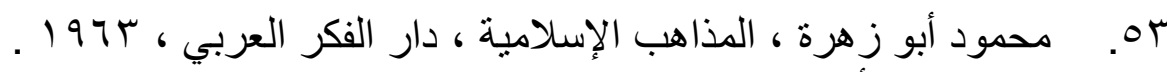

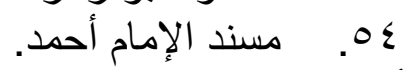
أطاريح الدكتور اه والرسنائل والبحوث أحمد : الرئ

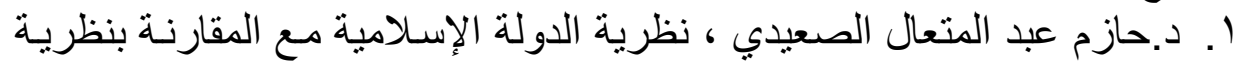

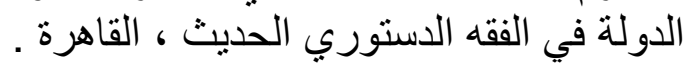

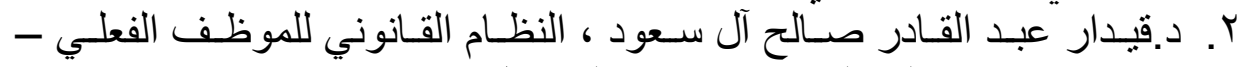

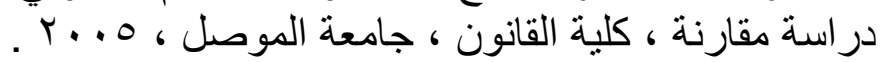

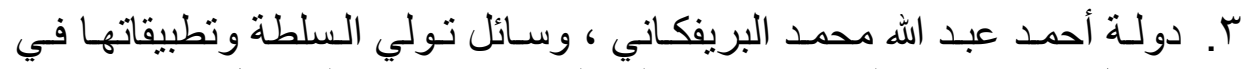

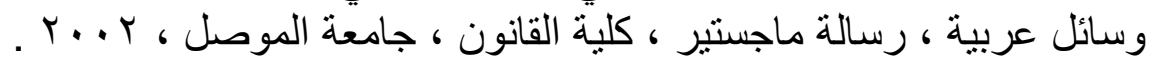


ع. عمار فرج حسن الأعظمي ، فلسفة السلطة ، رسالة ماجستير ، كلية القانون ،

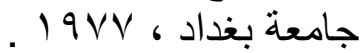

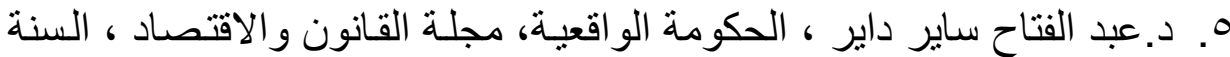

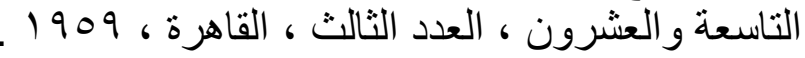

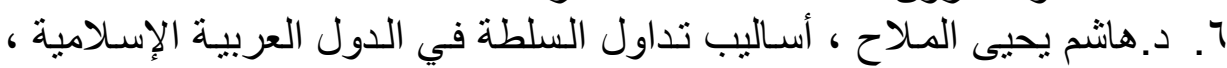

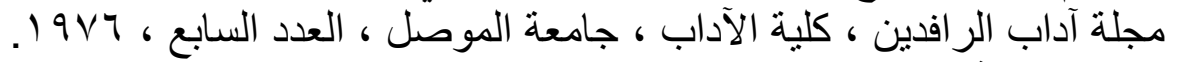
الإعلانات الدولية : الدابة البرن

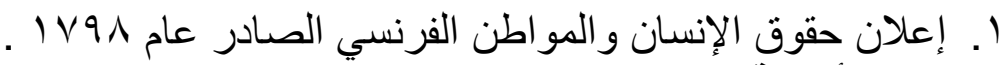

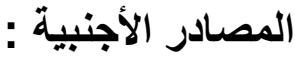

1. A.KH.Makhneko.The state Law of the socialist countries progress.Moscow.1976 .

2. Burdeau : Traite de science politique $2 \mathrm{em}$, ed, paris . 1966.

3. Jean-william laferreile pouvoir politique p.u.f paris. 1969 . 